Ev27h

1955

Robert A. Evers.

Hill Prairies of Illinois.

(1955) 
HUINOIS MISTORICA SURVEY 

of the

ILLINOIS NATURAL HISTORY SURVEY HARLOW B. MILLS, Chief

\section{Hill Prairies of Illinois}

ROBERT A. EVERS

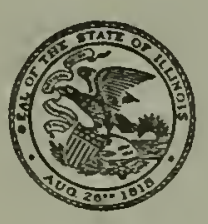

is

0
0
5
5
0
0
0
0
0

Printed by Authority of the

STA TE OF ILLINOIS

WILLIAM G. STRATTON, Governor

DEPARTMENT OF REGISTRATION AND EDUCATION

VERA M. BINKS, Director 
itUnDIS histofical SURVEY 


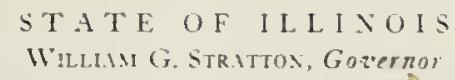

\title{
Hill Prairies of Illinois
}

\author{
ROBERT A. EVERS
}

Printed by - Iuthority of the State of lllinois

URBANA, ILLINOIS

Aluyst 1955 
S T A T E OF I L I I O IS

Wiliam G. Sikatron, Governor

DEPARTMENT OF REGISTRATION AND EDUCATION

TERA MI. BINKS, Dire.ror

BOARD OF NATURAL RESOURCES AND CONSERVATION

TERA M. BINks, Chetrman

A. E. Eaterson, Ph.D., fiology

A. Hi. Tir axi, Ph.D." Forestry

WALTlK H. NENHOUSE, Ph.D. Geology Roger ADists Ph.D. D.S. Chemistry ROISERT H. AVIJERSON, B.S.C. F., Engineering

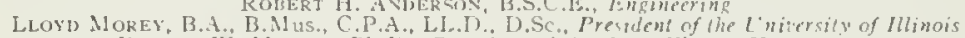

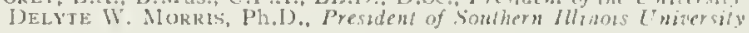

\section{NATURAL, IISTORY SURVEY DIVISION Urbana, Illinois}

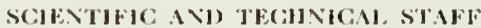

HARLOW B3. MLLLS, Ph.D., C'hrof

BESSIE B. E.wT. MIS., I ssistant to the Chite

Section of Econornle Fotomolosy

GForge C. DECKFR, Ph. D., finomologist and

Head H. BriciER, M.S. Entomologist

1. H. Brrcile, M.S., Entomologist
I. L. ENGLisir, Ph.D.. Entomologiv!

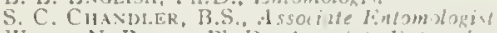

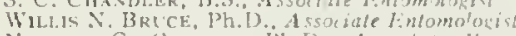

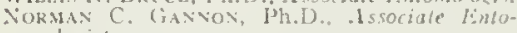
mologis!

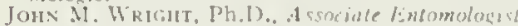

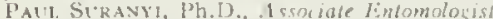

13. H lich

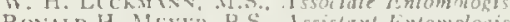

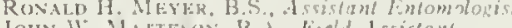

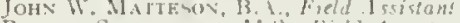
ROUERT SNETULViER. M1.S., Field A T.5es/am SUE E. WATKIS4, Teihnical A ssistont

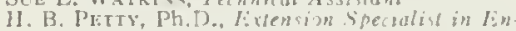
tomology

StErevso: Monke, 111, Ph.1)., Extension lipechalist in lintomology*

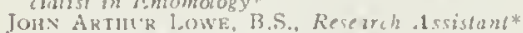
JoIN AKIIITR MOWE, B.S., Research Ass

CLARENCE E. WHITE, B.S. Resenth Assistant*

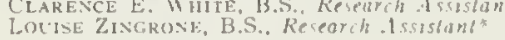

\section{Section of Fumistle Surveys and Insect} Jentlieation

H. H. Ross, Ph.D., Systematic Entomologut and II cod

MiltoN W1. SAvDERSON, Ph.D. Taronomist

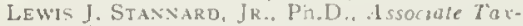

onomist

LEONORA K. Cilovo, M.S. Assistant Ta ronomist

Thonas E. Mlloore, MI.S., Teibnical Assistam

BARBARA GuTOWrKY. M.A. Teihnical Issisfant

\section{Sectlon of Aquatlc Biology}

George H:. Bexxett, Ph.D., Aqualic Biologist ond llead

Wirliam C. Starrett, Ph. D., Aquatic Biologist

R. W. Larialore, Ph.D., Associoie Aqualic buologish

Doxald F. Haxsex, Ph.D.. A sszsiam Iqualic Biologist

ROBERT D. Cromptovi Field d ssistant

LeoNard DURhaM, M. S., Research Assistont*

Williar F. Cullders, B.S. Te hrical Assistank
Section of Applied Boting and plaut l'athology

J. CEDRIC C.ARIER, D'B.D., Plant Pathologist ond Ilecul

J. I. Foienerg, I'h.D., Plant Palhologist

(i. iI. Borwe, ML.S., Issocme botanist

R. J. CAvipANA, ?h,D., Assistan Plani Pathol-

1. R. SEIJNEIJER, ['h.1). Assistanl Plant P'athelogis!

E. B3. Himelack, M.S., Assistant Plant Puthologis?

RralistR A. EVERS, Ph.1).. Assistant Botanist

Rovievid F. Fizz-(ieralb, B.A., Tichnical Irestant

J.AME: D. BHI.13RtCK, M.S., Reseurch Assistont*

\section{Section of Ginme Research ind Vinagement}

T. (;. Scotr, Ph. D., Gome Sipecinlist and Head

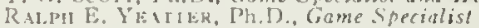
F. C BELIROAE B.S. Game S'pecialist

H. C. HANsov, il.S., I sstshne Game Specialist

J. S. Jokly 12h. D.. Assislunt Game Technicion

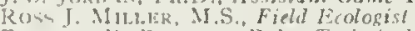

Fraice; 1). Ruburss, B.A., Technical A ssistant GIRGiNIA A. WIIPPLE, Techntial issistont

Jolls M. Schllutixg, Field A ssistant

Wirliay B. Ronertion, JR., Ph.D., Research issistant

JAMEs OpsinL. M.S.. Field Assistant*

\section{Setion of Publications and Public Relations}

JAME = S. AYIRS, B.S. Technicul Edilor and llead Blaxche P. You'ta. B.A., Assistanl Technical Eilitor

Willasa E. Chakk, Assistonl Teilinical l'holog. raper

Ililay DoBravic, B.A., Teithical Issistani

\section{Technical Jilurary}

RuTII R. WIRRICK, B.S., B.S.L.S., Teihnical

Librorian
OLGA E. GRIMINtier, M.S., dssistant Techniral Librariet

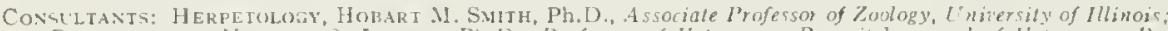
Parastology, Normav D. LEvise, Ph.1). P'rofessar of l'eleranary Parasilology and of l'elerinary Research, Liniersily of Illznois.

* Emplosed on co-uperative projects whth one wi several agencies: Illinois Agricultural Externsion Service, Illinois Department of Conservation. United States Army. Surgeon General's Uffice, Unite1 States Depart. ment of Agriculture. United States Fish and Wildlife Service, Unted States Puhlic Health. Service, and others.

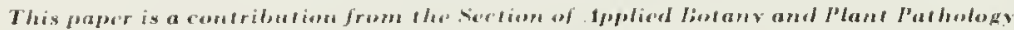

$$
(16062-1.11-5-55) \text { cation. }
$$




\section{CONTENTS}

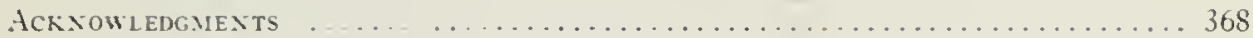

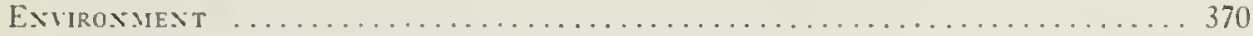

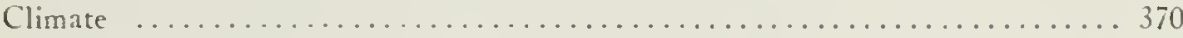

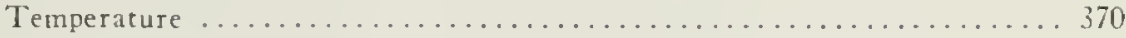

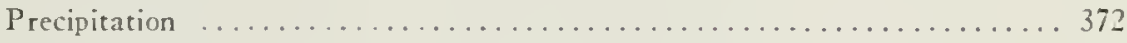

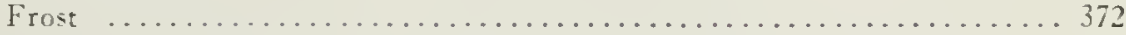

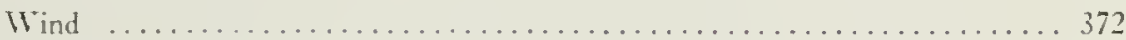

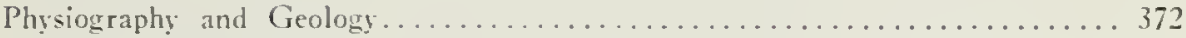

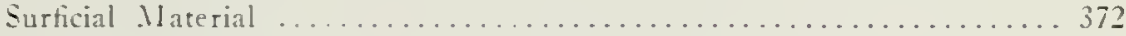

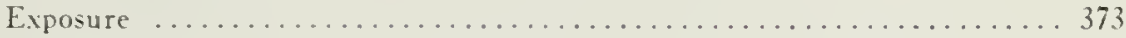

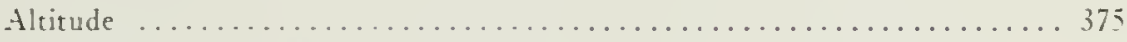

Parallel Tributary Valleģs......................... 375

Environmental Conclusions . . . . . . . . . . . . . . . . . . . 375

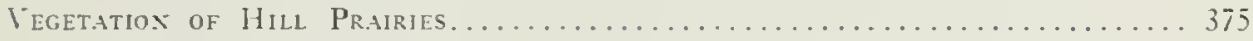

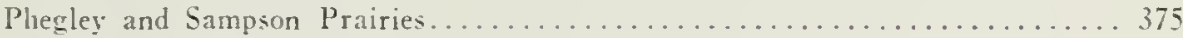

Study Procedures . . . . . . . . . . . . . . . . . . . . 378

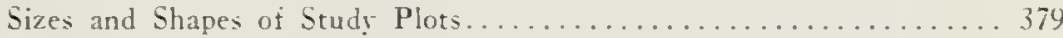

Method of Counting Plant Ĺnits................... 380

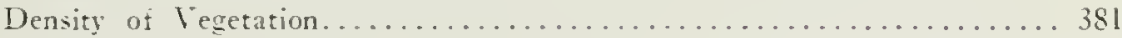

Grasses . . . . . . . . . . . . . . . . .

Plants Other Than Grasses...................... 382

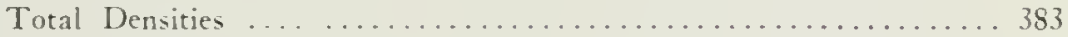

Ground Space of Plants ........................ 383

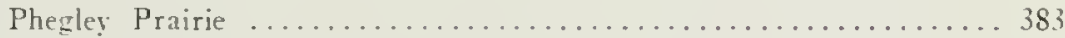

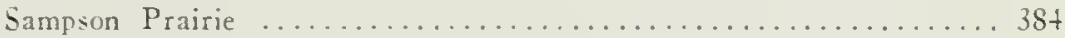

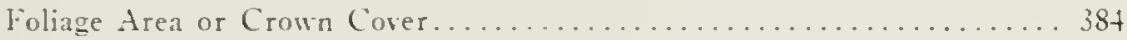

Arailable Space per Plant. . . . . . . . . . . . . . . . . . . . . 386

Numbers of Plant Species for Iarious Plot Sizes............... 387

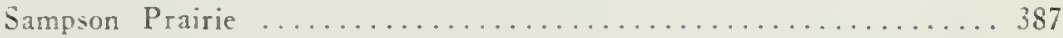

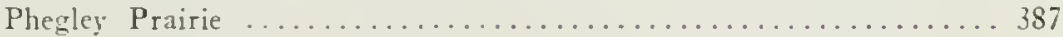

Frequency of Occurrence of Species....................... 389

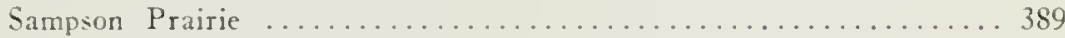

Phegley Prairie ................................ 390

Frequency Values for Combinations of Species................... 390

Species-Area Curve ............................. 391

Sumnary of Pastured and Lnpastured Prairies................... 392

Vegetation Characters From Other Stands.................... 392

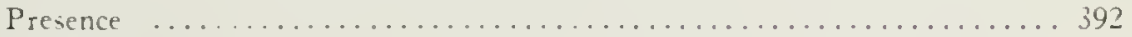

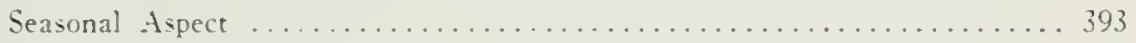

Vegetatioxal History and Slccession . . . . . . . . . . . . . . . . . . 393

Axxotated List of Hitl Primies . . . . . . . . . . . . . . . . . . . . . 395

East Dubuque to Grafton............................. 396

Along Rock. Sangamon, and Illinois Rivers..................... 401

Grafton to Cairo and Eliewhere in Southern Illinois............... 405

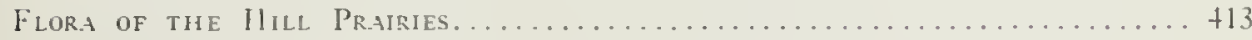

Annotated List of Species..........................

Géoraphical Relations of the Hill Prairie Flora....................ttl

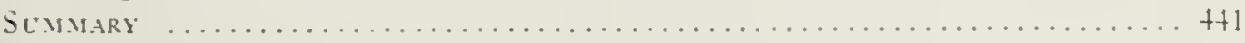

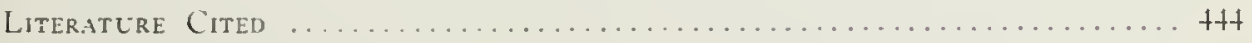




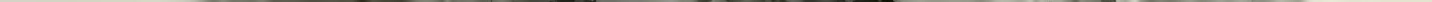




\section{Hill Prairies of Illinois ${ }^{*}$}

ROBERT A. EVERS

$\mathrm{O}$ I the sunny, windswept, upper slopes of some of the bluffs along the major Illinois streams are treeless areas distinctive enough to attract the attention of observing travelers. These areas are grassy strips or grassy openings on the otherwise forested slopes of the bluffs, frontispiece. Most of them have been little disturbed by man or domesticated animals. Those that are covered with prairie plants are prairies.

Prairies are grasslands. To many persons, prairies are flat grasslands. However, it is not topography but vegetation that distinguishes prairies and other plant communities. Forests occur on flat land or on slopes. So do prairies. Grasslands, or prairies, on pronounced slopes are hill prairies.

The term hill prairies was first used in $19+3$ by a University of Illinois botanist, Dr. Arthur G. Vestal, in his ecology classes and seminars to characterize prairies that occur on loess bluffs, on mounds, on steep, rocky slopes, on steep slopes of glacial drift, or on any other steep slopes. With few exceptions, the hill prairies of Illinois are not hill-top prairies; most of them occupy only the upper west- and southwest-facing slopes of elevations.

Most of the once extensive flatland prairies have disappeared from the Illinois landscape. There yet remain a few patches of these prairies on the till plains, but they have been very much disturbed by man or domesticated animals. The prairies of the bottomlands, the type studied by Turner $(193+a, 193+b)$, now occur only in small scattered patches, usually in field borders or borders of roadside ditches in the Mississippi and Illinois river valleys. There are still sizable areas of sand prairies of the type studied by Gleason (1910),'Gates (1912), Testal (1913),

*This article is based upon a thesis submitted by the writer to the Graduate College, University of Illinois, Urbana, in partial fulfillment of the requirements for the degree of Doctor of Philosophy in Botany. and others, but the extent of these prairies is rapidly decreasing as a result of the activities of man in converting them to fields of watermelons or cantaloupes, or to another type of grassland, the cornfield.

There remain on the Illinois landscape numerous tracts of hill prairie and, as these prairie slopes were never plowed, they are now the least disturbed type of prairie in the state. Although rather complete studies of till plain, bottomland, and sand prairies of Illinois have been published, until this time no comparable study has been done for the hill prairies of this state.

Several studies have been published on the hill prairies of other states. The study by Bush (1895) on the mound flora of Atchison County, Missouri, and the work of Steyermark (1940) on succession in Ozark glades of the same state concerned, in part, prairie on pronounced slopes. Studies of Pammel (1S96, 1S99, 1902) and Shimek (1910a, $19106,1911,1924)$ described the vegetation and enumerated the species of the loess bluff prairies in western lowa or of the prairie openings or grassy meadows on the lowa bluffs of the Mississippi River. Reports of Hanson (1922), of Costello (1931), and of Hopkins (1951) described prairies on loess bluffs along the Missouri River in Nebraska or prairies on loess hills in central Nebraska. A paper by Marks (19+2) characterized what he termed the "goat prairies" of Wisconsin as prairies located on slopes "so steep that only the nimble goat could graze them." Sites described in these papers were prairies on steep slopes, or hill prairies.

Perhaps the earliest reference in the literature to Illinois grasslands on the upper slopes of hluffs is found in reports on the geology of Greene County and of Scott County by Worthen (1S68). In these reports, Worthen described loess-capped bluffs with grass-covered knobs. These 
grassy knohs were prairies on steep slopes, or hill prairies. It is surprising that no earlier descriptions of hill prairies are extant. Certainly the French settlers saw the grassy slopes and perhaps named the village of Prairie du Rocher (Prairie of the Rock) after the prairie above the cliffs. 'The capable botanist, André Michaux, who traveled from Kiskaskia to Cahokia and visited the village of Prairie du Rocher in 1795, apparently made no record, in that part of his journal included by Sargent (1889), of grastands on the hiuffs. Early gazetteers, as those of Peck (1834) and lillsworth (1837), contain references to wet, dry, level, and undulating prairies, but apparently nothing about prairies on the blufts. Short (1S+5) wrote a good description of the autumnal aspect of flatland prairies; his journcy did not take him far enough to the west to include hill prairies.

Some references to hill prairies of 111 inois have appeared in the past 50 years. Hus (1908) described the blutfs in the vicinity of Collinsville and mentioned open hiltsides with grasses dominant and bluegrass the chief species. Vestal (1918) citcd numerous prairie inclusions near Charleston, deacribed their topography, and stated essential conditions for their presence. Woodard (192t) mentioned prairies on bluff-ridges. V'estal (1931) reported the occurrence of prairies on loess bluffs of the Mississippi River, and Vestal \& Bartholomew (1941) briefly: described some prairies on the loess bluffs of the 1 llinois River.

These authors were concerned only with lucal occurrences of hill prairies in 1llinois. They did not report on the extent of hill prairies in the state, nor did they report in detail on the flora of the hill prairies, the characteristic plants, relative abundance, presence and space relations as determinable in plot studies, or the origin and history of hill prairies. In order to obtain the necessary information for a study of these characteristics of hill prairies and for a description of hill prairie vegetation in Illinois, the writer made numerous plant collections and plant identifications from 61 hill prairies, fig. 1, having a combined area of more than 200 acres. Detailed data pertaining to the vegetation were obtained from two prairies by use of plot studies, as explained in a later section of this paper.

The locations of some hill prairies were determined by the writer from the field notes made by Dr. Vestal during his travets in the state; of others, as the prairic southeast of Menomince Station in Jo 1)aviess County, from a study of aerial photographs. 'The majority', however, were found by field reconnaissance of the writer. During late autumn and early spring, hill prairies can easily be seen from the roads near or at the bases of the bluffs. Such roads, called bluff roads on some maps, are common in both the $\mathrm{M}$ ississippi and Illinois river valleys. In the Mississippi River valley, bluff roads were traveled by the author from Olive Branch in Alexander County northward to it point north and west of Glen Carbon in Madison Connty and from Hamburg in Calhoun County the 275-mile distance to the northwest corner of the state, except for short gaps in Hancock, Henderson, Mercer, Rock Island, and Jo Daviess counties. In the lower Illinois River valles, bluff roads were traveled from Grafton to Hennepin, except for a few gaps in Mason and Tazewell counties. 'The locations of prairic sites were marked on maps of sufficient scale to be used easily.

Not all hill prairies seen were visited, nor were bluffs of small streams exanined for occurrences of hill prairies. Doubtless small prairie openings occur on the bluffs of small streams in the western part of the state. In eastern Illinois, I'estal (1918) observed several prairic openings along the Embarrass River near Charleston.

\section{ACKNOWLEDGMENTS}

It is indeed a pleasure to acknowledge the assistance given by 1)r. A. G. Vestal, Department of Botany, University of $11 \mathrm{i}$ nois, in the preparation of this study. 1 wish to thank him for his willingness to direct this investigation and for the many helpful suggestions he made during its progress.

Dr. L. R. Tehon, now deceased, and Dr. H. B. Mills, of the Natural History Survey, greatly facilitated the progress of 


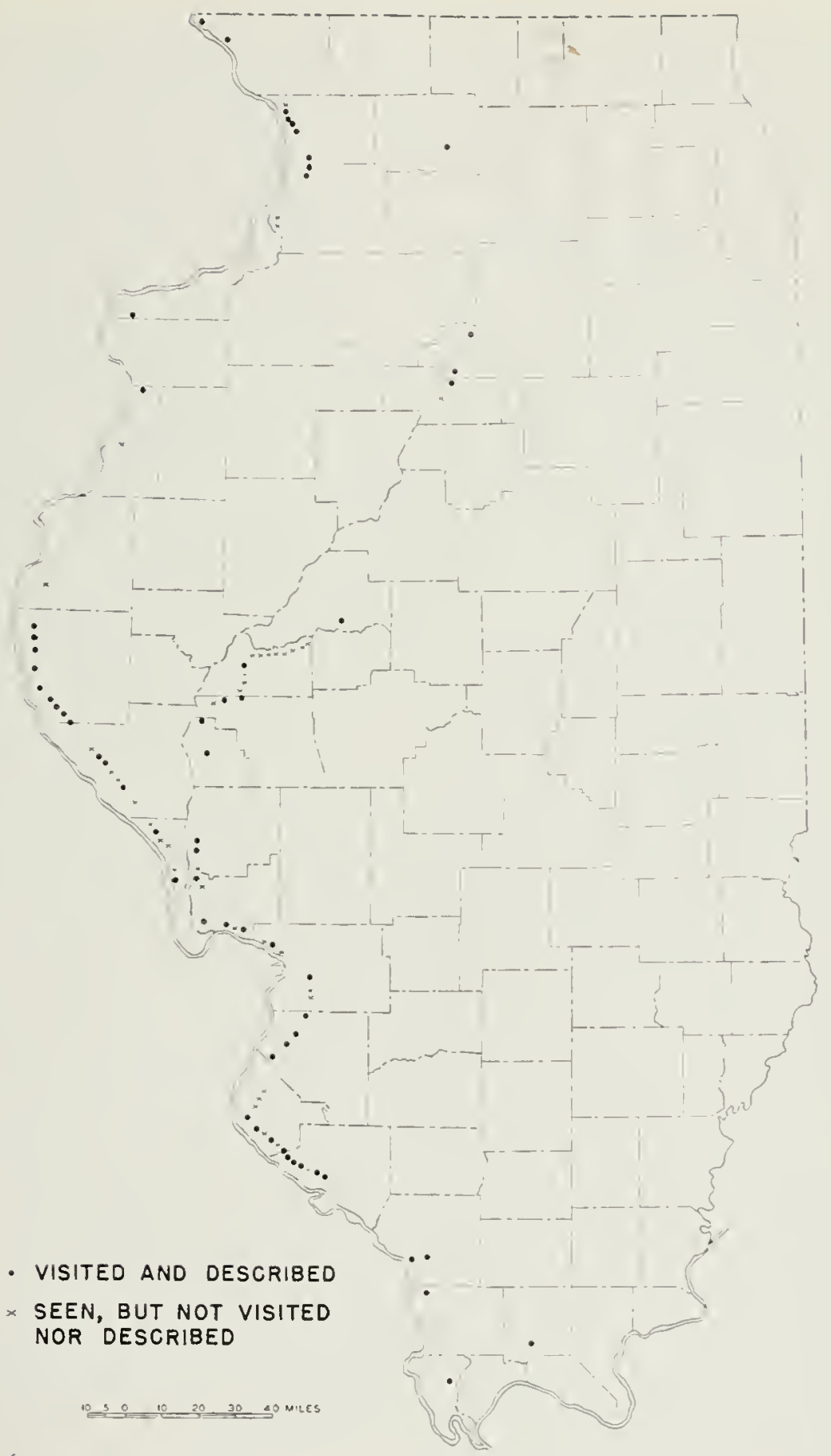

Fig. 1.-Location of the Illinois hill prairies which the author visited and of those which he saw only from a distance during the field work for this report. Hill prairies are most numerous on bluffs that trend northwest and southeast and have upper slopes facing the southwest. Bluff. of tributary streams were not examined for occurrences of hill prairies. 
this study; for their help I an truly grateful.

Also, I wish to acknowledge here the assistance given by Mr. W. M. Phegley and Mr. I. I. Steibel of Prairie du Rocher, both of whom are now deceased. Some of the vegretation studies for this inrestigation were accomplished through their kind (o)-speration. I wish to thank Dr. G. WT. White, Department of Geology, University of Illinois, and Dr. H. B. Willman and Dr. G. E. Ekblaw, Illinois State Geological Survey, for information concerning the geology of hill prairies; Mr. B. M. Woods, University Library Map Room, for his efforts to locate suitable acrial plotographs: Mr. Julian Noill, Eelst St. Louis, for assistance in the study of hill prairies in that region: Dr. J. I. Forsherg, Dr. P. F. Hoffman, Mr. I. M. Curfman, and Mr. R. E. "Teegardin, while memhers of the Vatural Ilistory Survey staft, for assistance with the statistics. the hydrogen-ion determinations, and the maps, diagrams, and drawings: and Mr. I. S. Ayars, also a Survey staff member, for lis assistance with editorial problems.

Others 1 wish to thank for their contributions to this investigation are Dr. M. Wr. Sanderson, 1)r. H. H. Ross, Dr. L. J. Stamnard, Illinois Natural Jlistory Survey; Mr. and Mrs. F. Mr. Evers, Quincy: Mr. Raymond Hatcher, Murphysboro: Dr. I. W. Hall, University of Minnesuta; Mr. and Mrs. B. C. Trees, East St. Louis; Frederick Evers, Clara V. Evers, and Marilyn Briggs Ellerman, Champaign; and Miss Virginia Frank, Chicago.

Mr. Dewey Clark. Quincy, took the pictures for the frontispiece and fig. 16. Mr. W. E. Clark, Natural History Survey staff, took the photographs used as figs. $3,17,18,22$, and 24 . All other photographs were taken by the author.

The plant nomenclature used in this study is for the most part that of Hitchcock (J950) for grasses and Fernald (1950) for other plants. Where the nomenclature in this report does not conform to that in the manual of Hitcheock or that of Fernald, the manual mame is included in hrackets in the section on the flora of hill prairies. In instances in which a name of long standing has been changed in recent manuals, the former name, in brackets, also appears. Common names not from the above manuals are from Deam (I940) or Jones (1950).

\section{ENVIRONMENT}

The occurrence and distribution of plants, and consequently plant communities, is detcrmined largely by climate and other envirommental conditions, including the soil or substratum in which they grow. Some of the environmental conditions favoring the existence of hill prairies in Illinois are discussed in the following sections.

The climate in practically any part of llhinois permits growth of either prairie or forest. 'Jhe circumstances (aside from those of accident and of history) which tip the balance and thus determine the details of local distribution of prairie and forest are chiefly the controls exerted by topograpliy.

\section{Climate}

The following information on climatic conditions applies to the Mississippi River valley along the western border of Illinois, the region of the majority of hill prairies observed for this report. With few exceptions, the climatic data, taken from Page (1949), are from weather stations located along the Mississippi River. Exceptions are the data from the Mount Carroll, Carbondale, Anna, and Greenville weather stations; these stations are, respectively, about $9,11,12$, and 33 miles from the nearest hill prairies.

Temperature.- The average January temperature along the western border of Illinois varies from 19.6 degrees Fahrenheit in northwestern Illinois (Dubuque, Iowa. weather station) to 36.2 in southern Illinois at Cairo. The average July temperature is $7+.6$ degrees in northwestern, 80.2 in west-central (Quincy weather station), and 79.8 in southwestern and southern Illinois (St. Louis, Missouri, and Carbondale, Illinois, weather stations). In Cairo, at the southernmost weather station in Illinois, the average July temperature is 79.5 degrees. The re- 


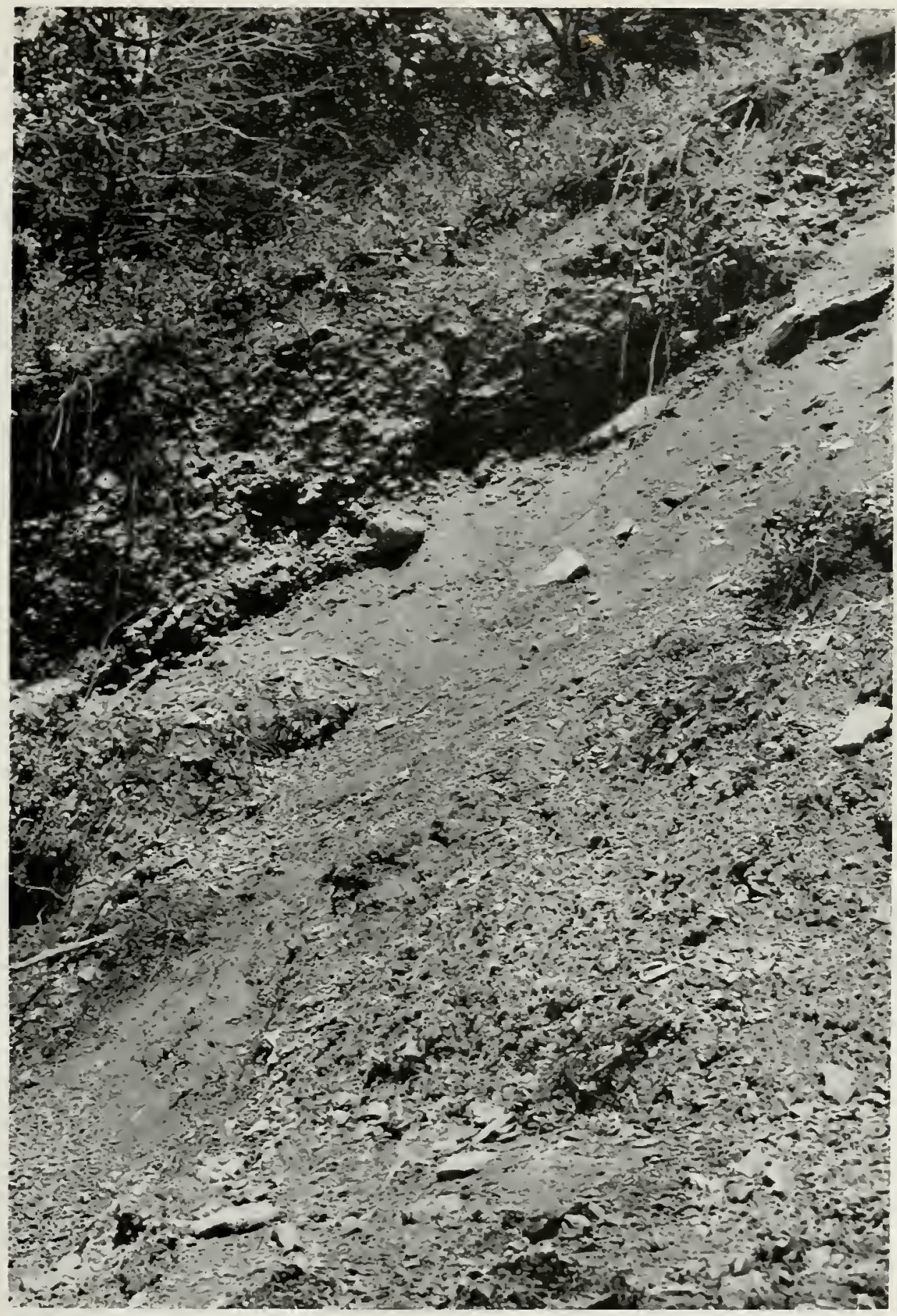

Fig. 2.-In excavation in the toe or basal slope of a bluff southwest of Renault, Monroe County, which shows the characteristics of the rock fragments that form the basal slapes of many river bluffs. The fragments have spalled from the cliff above the slope. 
corded extremes of temperature are -35 degrees at Jount Carroll (January 22, $1930)$ and 115 degrees at Greenville (July, 1936). "The highest reourded tenperature in that part of 1 llinois along the Mississippi River is 114 degrees, recorded at Quncy in July, 1936.

Precipitation.- The average annual precipitation along the western horder of lllinois varies from 33.13 inclues in northwestern Illinuis (I)ubuguc, Jowa, weathes station) to 11.39 at (airo and 47.43 at Anna. Averages of snowfall. notahly less than 10 per cent of the annual precipitation, are 9.9 inches at Cairo and 32.3 at Mount Carroll. The wettest month in northern and west-central Illimors is June. The wettest montly in suththern Illinois varies with location; May is the wettest montly at Anna. March the wettest at Cairu. Buring the growing season, April through September, Cairo receive 49.41 per cent of its anmual rainfall; Anmi. 52.77 per cent; Quincy, 65.26 per cent; and northwestern lllinois (1) 1 bucue, lowil, weather station), 66.77 joer cent.

Frost. - The anerage frost-free proind. along the western burder of lllinois are April 19 to October 16 in northwestern llinusis (1)ubugne, lowa, weather station), April 13 to Oevober 20 at Quinc! in west-central Jllinnis, April 9 to (Octorber 26 at Anna, and March 30 to October 29 at Cairo.

Wind.-The prevaling wind in winter a'ong the western border of lllinois is from the northwest; in summer, it is from the southwest, often hot and dru.

\section{Physiography and Geology}

Steep slopes or hluffs abut the broad, deeply alluviated floodplains or bottomlands of many of the major stream valleys in Illinois. The continuity of the bluffs is broken by tributary streams that enter the main valleys. The underlying hedrock and the surficial material determine the form of the bluffs.

The bedrock of the bluffs on which hil] prairies occur is limestone, dolomite, sandstone, shale, or combinations of these; the geological ages of the uppermost strata range from Middle Ordovician to Upper
Pennsilyuian. In most places, the bedrock crops out to form a cliff as much as 200 feet ahove the valley floor. Frequently, a stony talus or tos slope is present at the base of the cliff, fig. 2, and, unless recently disturhed, supports a mixed forest. A mantle of surficial material cosers the bedrock at the top and forms the brow or upper slope of the bluff. In some places, as in parts of Morgan and Madison countics, sandy loess and colluvium completely mantle and conceal the bedrock.

Surficial Material.-Surficial material, the unconsuliclated material ibove the hedrock, may he residual or transported. Residual material, which supports hoth prairie and forest in lllinois, cecurs south of the glaciated area, ai, for instance, on the rocky slopes at Cave Creek prairic and the cleerty ridge-top at Tamms. On most utluer prairic slopes the surficial material is transported-loess or glacial drift.

Loess, a windblown accumblation of silt with subordinate clay and minor amounts of fine sand, wecurs wer large areas of the Midwest. "One of the most important and hest-knowrs occurrence; of loess in the worlal is in the Missiesippi River Basin" (Leighton \& Wi!lman 1950). Loess mantles most of 11 linois except the large stream vallers and areas of lake sediments and sond dunes.

The eolian hypothesis of the origin of loess deposits is the one accepted hy most geologists who have studied this material extensively. Udden (1894) wrote, "From a dinamical point of view the wind-theory would appear to furnish an adeculute explanation of the occurrence of the loess in the Mississippi valley, at least as to most of its phases." Shimek (1896) adbocated the eolian hypothesis and based his conclusions in part upon the land snail whells he found in loess. Chamberlin (1897) presented the hrpothesis that loows (of the Mississippi Ialley) is a wind deposit and that the sources of the material were the floodplain deposits of the glacial rivers. The bypothesis of the origin of loess deposits from backswamp sediments (Russell 194t) does not seem tenable for lllinois.

The thickest loess deposits in Illinois 
are found along the east blutts of the Mississippi and Illinois rivers, where, in some places, they are more than 300 inches in depth. Such thick deposits occur in places where the valley changes from a northwest-southeast trend to one that is north-south or northeast-southwest, as in
In lllinois. soils derived from loess support both piairie and forest.

The only blutf prairie slopes that are mantled by glacial drift and that the writer examined for this report are in Putnam County. These bluffis were last covered by ice during the lazewell sub-

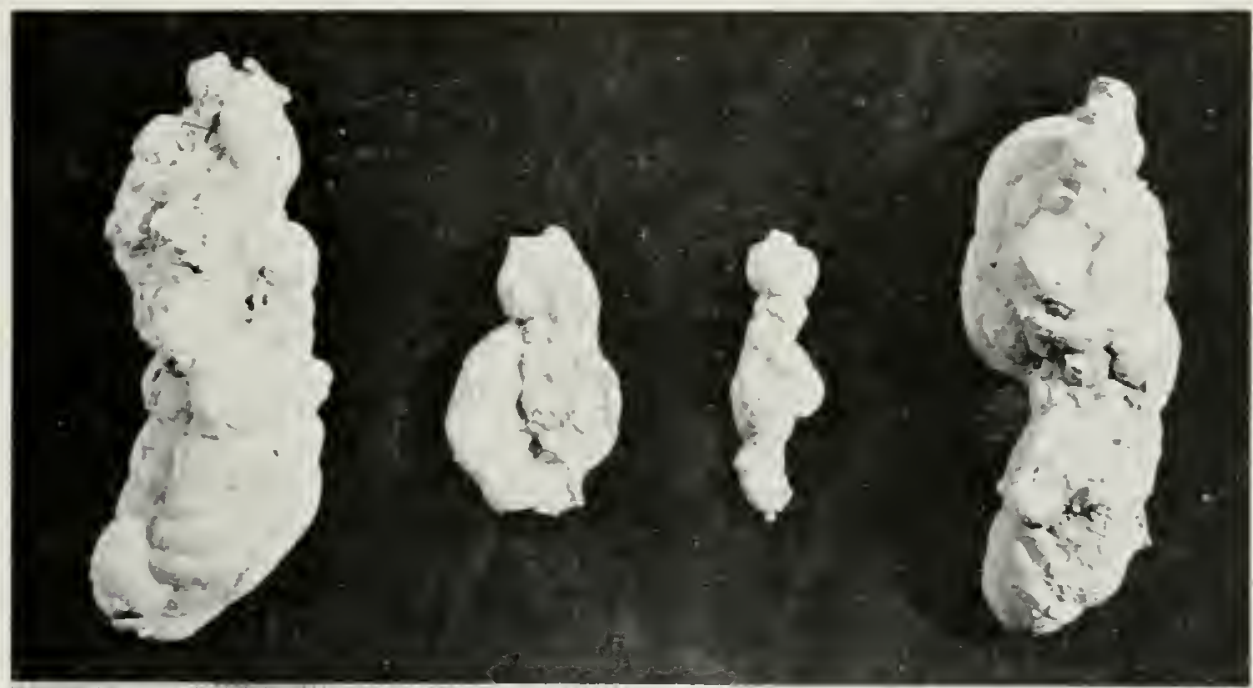

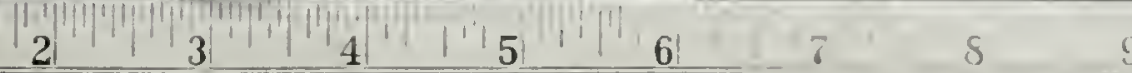

Fig. 3.-Calcareous concretions or "loess kindchen" from Phegley hill prairie near Prairie du Rocher, Randolph County. Such concretions are common on many prairie slopes in Illinois.

Carroll, Madison. and Jackson counties. Other deposits of great thickness occur just east of the wide portions of the main vallers, as east of the Illinois River valley from Mason County south into Morgan County. Away from the main river vallers the loess deposits become progressively thinner. Not only do the deposits of loess become thinner but also the mean particle size decreases with distance from the bluffs (Smith 19+21. Loess on the bluffs in many places is somewhat sandy.

The hydrogen-ion concentration of loess, as determined with a Peckman $\mathrm{pH}$ meter in samples from 10 hill prairies in southern and central lllinois, ranges from T.S6 to $8 .+1$. All sumples, when treated with dilute hydrochloric acid, effervesced freely. showing the presence of calcium carbonate. Calcium carbonate is often found in the form of concretions, "loess kindchen," fig. 3, on prairie slopes. stage of the Misconsin glaciation, fig. 4 . Soils derived from till support hoth prairie and forest in Illinois.

Exposure-Hill prairies are most abundant on the northeast sides of the valleys, fin. 1, where the bluffs trend northwest-southeast, or on bluffs that border the wide, fat bottomlands or broad, Hat terraces over which winds blow with little hindrance, or on bluffs that are high. Certain physiographic situations, direction and steepness of slopes, altitudes of hluffs. and width of adjacent bottomlands are very advantageous in bringing about high temperature and low humidity, two conditions that favor a high evaporation rate, which in turn favors prairic (Shimek 1911). Southwest- and west-facing bluff slopes receive more nearly at right angles the rays of the loot afternon (2 o'clock) sumner sun than do other slopes. Slopes that face these directions are subject to 
higher temperatures. Such slopes, especially those of high bluffs, are also directly exposed to the prevailing southwesterly

\begin{tabular}{|c|c|}
\hline STAGE & SUB-STAGE \\
\hline \multirow{5}{*}{ WISCONSIN GLACIAL } & MANKATO \\
\hline & CARY \\
\hline & TAZEWELL \\
\hline & IOWAN \\
\hline & FARMDALE (PRO -WIS.) \\
\hline SANGAMON INTERGLACIAL & \\
\hline \multirow[t]{2}{*}{ ILLINOIAN GLACIAL } & $\begin{array}{c}\text { BUFFALO HART } \\
\text { JACKSONVILLE } \\
\text { PAYSON }\end{array}$ \\
\hline & LOVELANO (PRO-ILL.) \\
\hline YARMOUTH INTERGLACIAL & \\
\hline \multirow[t]{2}{*}{ KANSAN GLACIAL } & \\
\hline & PRO-KANSAN? \\
\hline AFTONIAN INTERGLACIAL & \\
\hline NEBRASKAN GLACIAL & \\
\hline
\end{tabular}

Fig. 4.-Classifcation of geologic time during the Pleistocene Period. (After Leighton \& W'ilman 1950.) winds of the growing season, which increase the water-loss both from plants and the surface soil. The upper bluff slopes are consequently extremely xeric and support prairie rather than forest.

Where the bottomlands are wide, wind movement is unimpeded for some disstance. Brow slopes of bluffs bordering such hottomlands are seric. Accordingly. hill prairies are common in the northern part of the American Bottoms in Madison and St. Clair counties where the Mississipi River valley is wide. In northern Cass County, hill prairics are found on bluffs that trend almost east-west and that horder a broad, flat, sandy terrace that extends to the lllinois River, which here flows southwestward. The xeric conditions on these brow slopes result in part from the movement of westerly wind. over the broad, flat, sandy terrace and in part from the deep mantle of very sandy. loess, which favors rapid loss of water by durnward percolation.

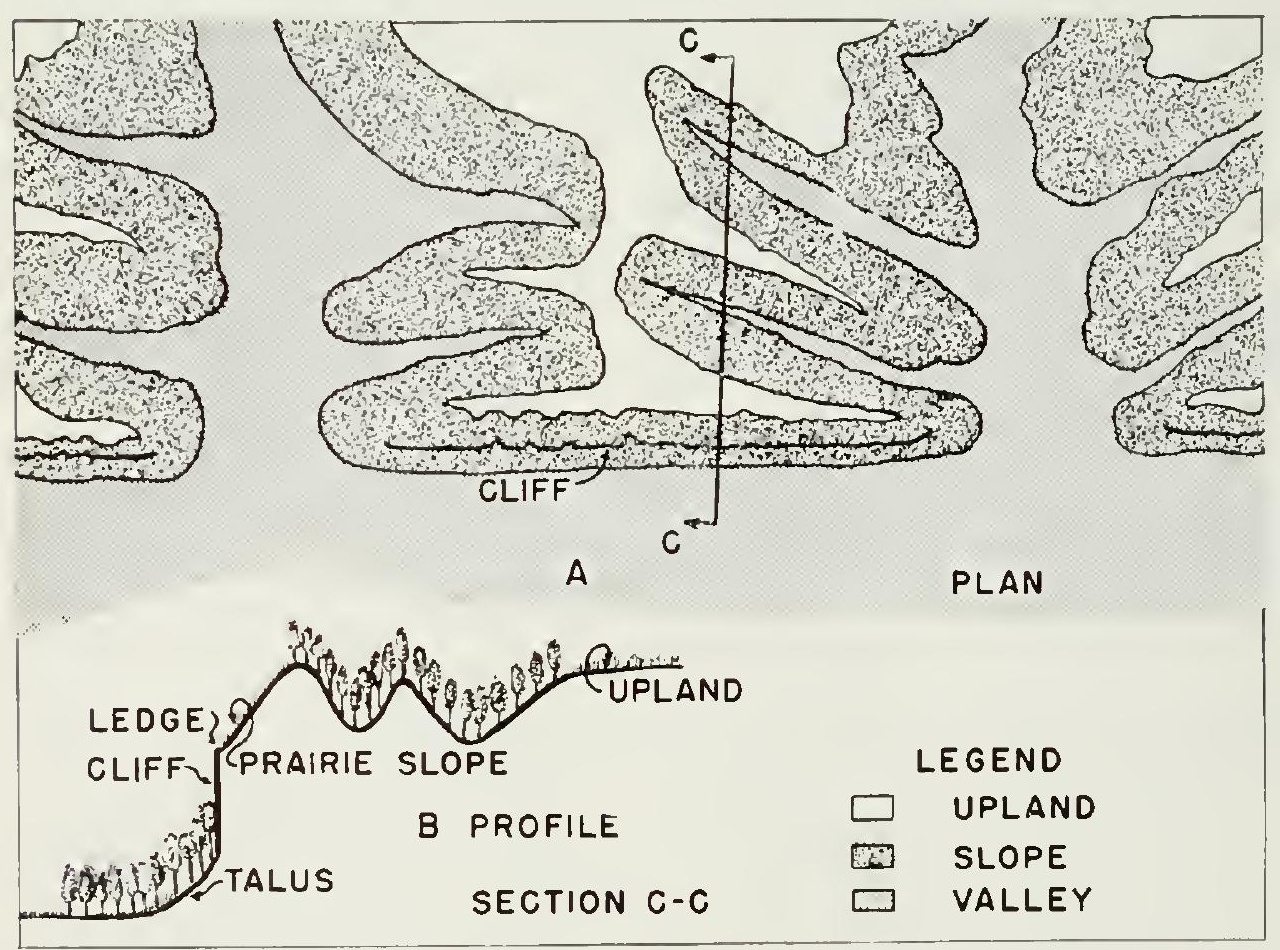

Fig. 5.-Schematic plan, $A$, and profile, $B$, of a bluff of type common along major stream vallevs in Illinois. The steep ralley wall between the two large tributary valleys ir the p!an is the bluff shown in the profile (section C-C). The bluff includes a talus or toe slope, a cliff, a rock ledge, and an upper or brow slope, which in the profile shows a cover of prairie. 
Hill prairies are absent from the generally northeast-facing slopes of the bluff: on the southwest sides of vallers; these slopes are covered by forests except where ther have been cleared and are now in cultivation.

Altitude.-A relationship apparently. exists between height of the bluffs and occurrence of hill prairies. More prairie openings and prairie strips are found on the Mississippi River bluffs in Pike, Calhoun, Monroe, and Randolph counties where the bluffs are high than on those hluffs just north or south of Quincr in Adams County where the bluffs are low. At Clendenny prairie (Calhoun County), the bluff rises: 220 feet above the bottomland; at Sessions (Pike Counts) $2+0$ teet: at Fults (Monroe Countr), $3+0$ feet; and at Phegley and Sampson (Randolph County), 310 feet. The bluffs north of Quincy are only slightly more than 100 feet and those south of Quincy are but 120 feet above the Missisippi River bottomland.

Parallel Tributary Valleys-During the course of field work, the writer observed an interesting feature of the hluffs. In $3 t$ of the 61 hill prairies risited, trihutary vallers are found approvimately parallel to and short distances back of the bluffs, fig. 5. In each of the 34 sites, the area between the major stream valley and the parallel valley, or vallers. is a narrow ridge that is joined to the upland berond by another narrow ridge more or less at right angles to the bluff. Hill prairies grow on the upper slope of the ridge that faces the major stream valley, a slope referred to as the upper bluff slope or the brow slope. Narrow ridges of thitvpe occur where streams have cut back into the ralley wall and where, at approximately right angles to them, their tributaries have developed. "The tributary" valleys, mostly parallel to the blufts, are $V$-shaped and forest covered.

\section{Environmental Conclusions}

As the climate and soils of Illinois permit the growth of both prairie and forest it can be concluded that certain geomorphic conditions are accountable for the occurrence of hill prairies on the upper bluff slopes. Loxation, the place in reference to major stram valleys, and topography. largely the result of the geomorphic history of the region, exert strong influences or controls, that are responsible for the presence of hill prairies. The growth of grassland rather than forest on the upper hluff slopes is attributed to priority of occupation by prairie species and to the xeric conditions that are produced by the combination of local exposure to the sun and to the wind (especially to wind moving unimpeded across wide foodplains), the height of the bluffs above the adjacent bottomlands, the steepness and direction of the upper slopes, and the permeability of the substratum. 'Thus, the hill prairie community is the result of a complex set of conditions, the effectiveness of which is determined by location and topography.

\section{VEGETATION OF HILL PRAIRIES}

The tspical regetation of hill prairie is the bunch-grass type. In most places, Indropogon scoparius is the dominant species. In some places, such bunch grasses as Bouteloun curtipendula, A. gerardi. and Sorghastrum nutans are locally dominant. In order to learn about the regetation, its density, the ground space it occupies, the foliage area or crown cover, the available space per plant, and the frequency of occurrence of species in plots of several sizes, the writer made detailed studies of hill prairie vegetation br means of plot studies in two prairies. He also made studies of some characteristics of all stands from species lists and field notes.

\section{Phegley and Sampson Prairies}

From the 61 hill prairies that he visited, the writer chose Phegley and Sampson hill prairies for the detailed vegetational studies. These areas are on the same hluff ridge. In their surface features. Phegley and Sampson prairies are tupical of hill prairies. There is a rock ledge and cliff at their hase. A stony slope lies above the rock ledge, and loess caps the bluff. Each prairie area possesses spurs and coves. At the time this study was made, prairie covered both the stony 


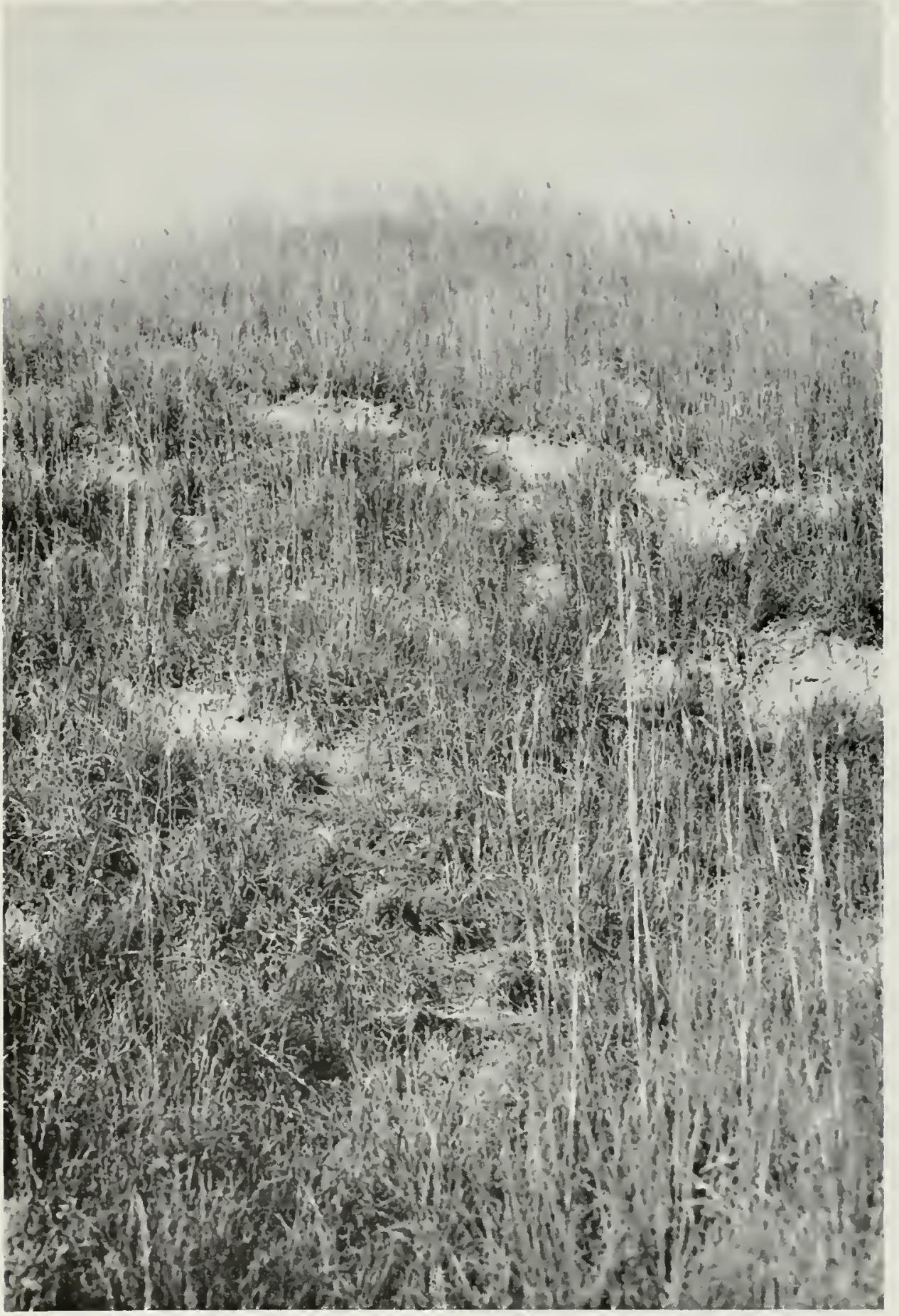

Fig. 6.- Steep spur front in unpastured Sampson hill prairie, north of Prairie du Rocher, Randolph County, showing some slumping of the loess. 


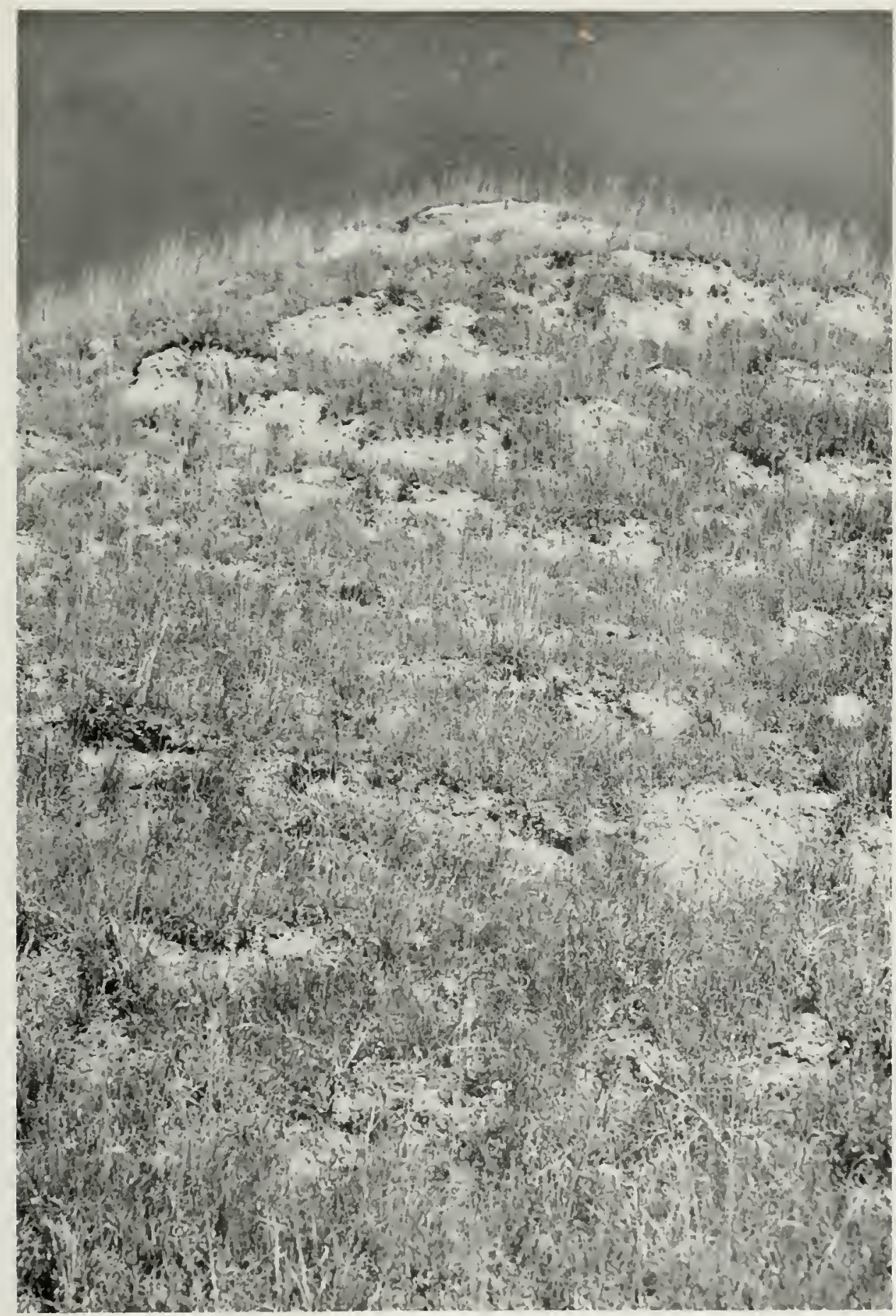

Fig. 7.-Steep spur front in pastured Phegley hill prairie, north of Prairie du Rocher, Randolph County, showing considerable slumping of the loess. 
and loess slopes. The Phegley prairie was pastured; the Sampson was not. Thus, it was possible to compare pastured and unpastured prairie slopes in the same locality.

Because Phegley and Sampson prairies were accessible to the writer by automobile, no laborious and time-consuming ascent from the bottomland, up the basal slopes and over the rock ledge, was neces- sary; steep climbs are necessary to attain the majority of hill prairies in Illinois.

Study Procedures.-For detailed vegetation studies in hill prairie, the upper slopes of spurs seemed to be the hest sites because these slopes had a vegetation that was nearly "pure" prairie, and they had surfaces that showed little erosion. The steep spur fronts, figs. 6 and 7 , contained species characteristic of prairic but showed

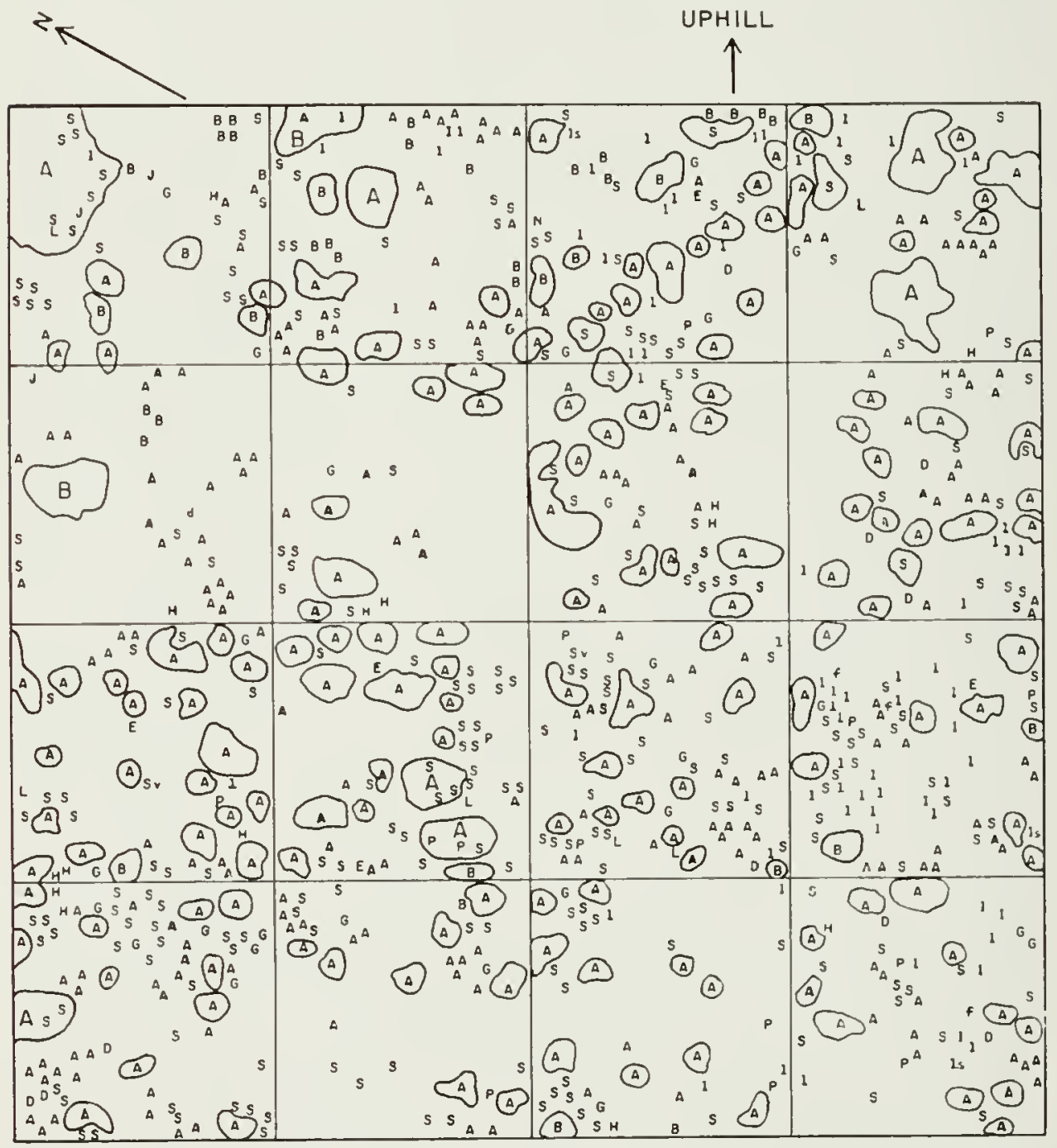

Fis. 8. - A 1-milacre quadrat in the pastured Phegley hill prairie, charted October 9 and 10, 1951, by A. G. Vestal and R. A. Evers. A. Andropogon scoparius; S, Solidago nemoralis; I, Lespedeza stipulacea; B, Bouteloua curtipendula; G, Gerardia sp.; P, Petalostemum purfureum; H. Houstonia nigricans: D. Desmodium ciliare; L, Lespedeza capitata; E, Euthorbia corollata; f, Cassia fasciculata; J, Juniperus airginiana; $1 \mathrm{~s}$, Linum sulcatum; N, Senerio plattensis: v, Polygala zerticillata; and d, Hedeoma hispida. 
more or less slumping of loess and, as a consequence, possessed sizable areas without plant cover. The more gentle slopes near the bases of the prairies had less severely eroded surfaces, and consequently more plant cover. than the steep spur fronts, but they contained more species characteristic of rock ledges.

Sizes and Shapes of Study. Plots.-A 9-milacre square was staked on the upper slope of a spur of each of the prairies. Phegley and Sampson. These plots were located at some distance from the crest of the bluff in an attempt to exclude forest plants and pasture weeds. Each 9-milacre square was then divided into nine 1-milacre quadrats $(0.001$ acre or $4.0+6$ square meters). The central milacre of the 9 milacre grid was selecied for mapping.

Each central milacre was divided into

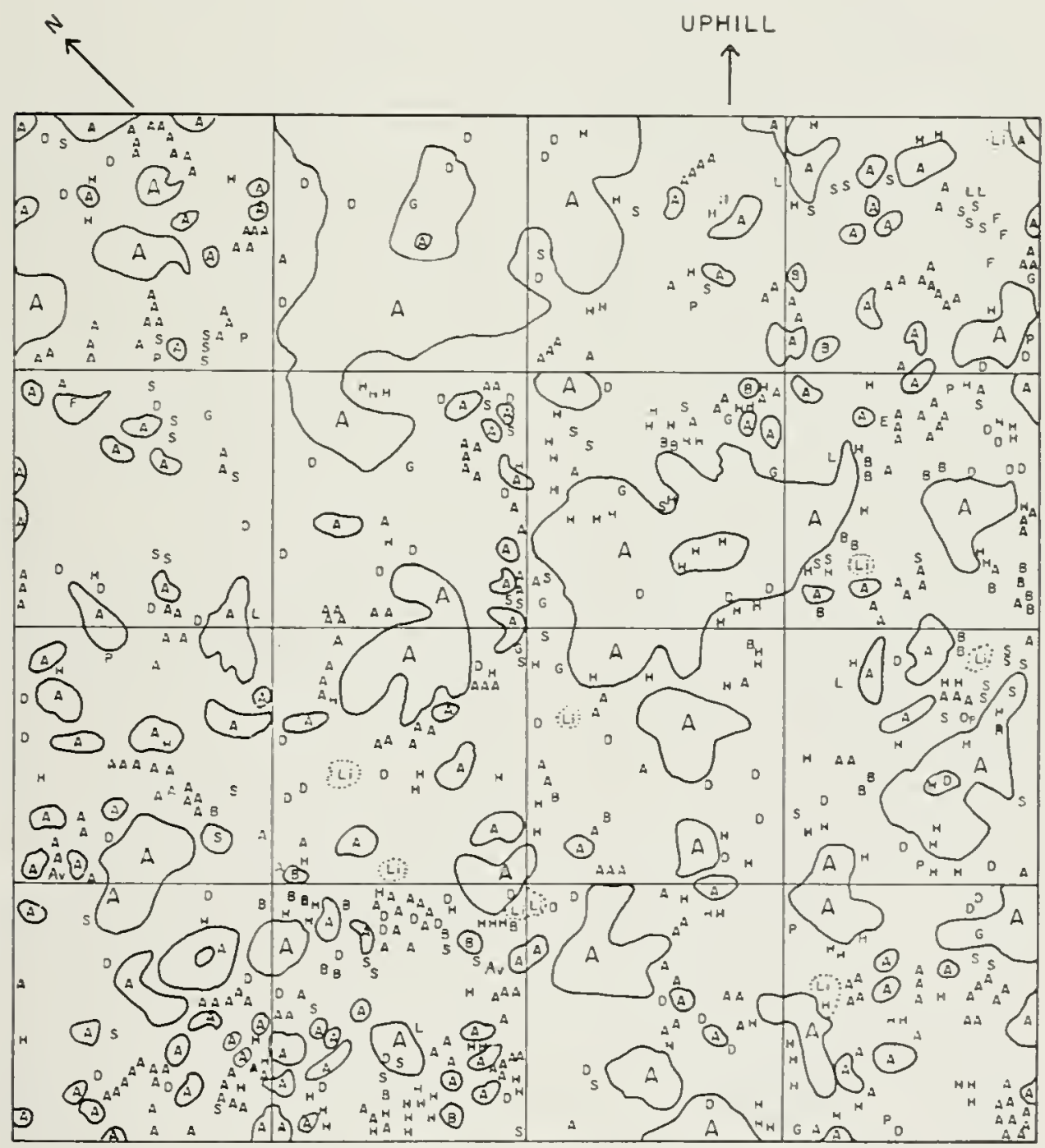

Fig. 9.-A 1-milacre quadrat in the unpastured Sampson hill prairie, charted October 15 and 16, 1951, by R. A. Evers. A. Andropogon scoparius; Li. Lecidea spp.; H. IJoustonia nigricans: D, Desmodium ciliare: S, Solidago nemoralis; B. Bouscloua curtipendula: G, Gerardia sp.: P, Petalosiemum furfureum: F, Andropogon gerardi; L, Lesfedeza capiasa; Ar, Agave irirginica: E, Euphorbia corollaia: Op. Opunita rafinesquii. 
$6 t$ small squares of 1 t milacre (approvimately 6.25 square decincters) io facilitate mapping. These small units were combined in working over the data to give 1 16- 1 to, and 1-milicere plots. "lhe central milacre quadrat in the Phegley pratiric was mapped, fig. $S$, and the shouts in this milacre were counted on ()ctober 9 and 10, 1951, by the writer each with an area of 5 milacres and five each of 10 milacres. Species lists were then compiled for the staked areas of each prairie by units of $1 / 6+1,16,1+1,3$, $5,9,10,25,50$, and 75 (303.5 squate nucters) milacres.

From data obtained from the staked areas, it was possible to determine the number of plant species and number of

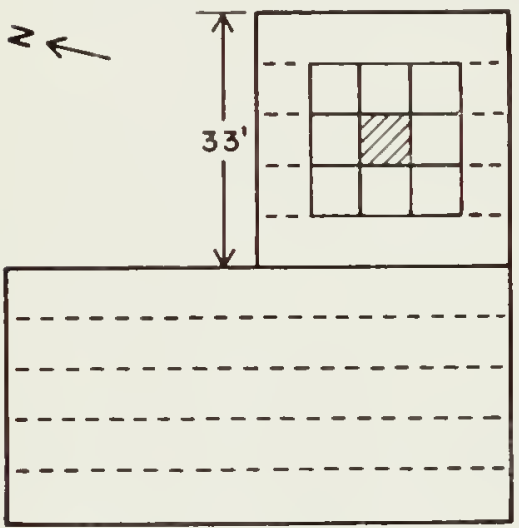

SAMPSON (UNGRAZED)

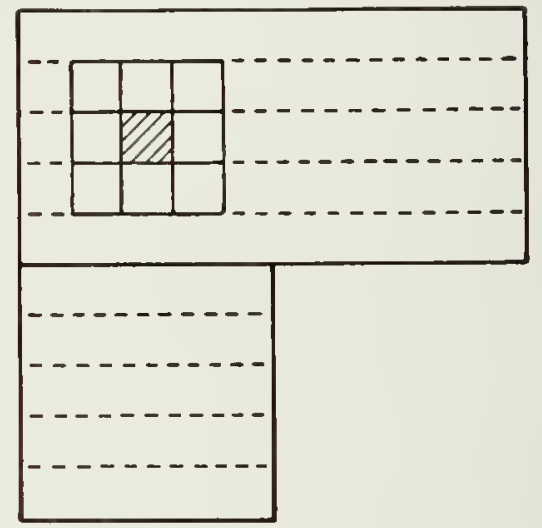

PHEGLEY (GRAZED)

Fig. 10.-Arrangement of plots and strips in two hill prairies. Each shaded square represents the mapped central milacre of a 9 -milacre grid.

with the assistance of Dr. A. G. Vestal; the central milacre in Sampson prairie was mapped, fig. ?, and the shonts were counted on Octoher 15 and 16, 1951, by the writer. In addition, a list of plant species was made for each 1 t milacre in the other 8 milacres of each of the 9-milacre grids.

In order to find the increase in number of species with an increase in area, the writer staked a 25-milacre square and a 50-milacre rectangle in each of the two prairies, fig. 10. In Phegley, the 25-milacre square was downslope from the nortl half of the 50-milacre plot, the half that included the 9-milacre square. In Sampson. because of the proximity of wondland. the arrangement could not be made identical with the arrangement of plots in Phegler: the 9-milacre square was inside the 25-milacre square; the south half of the 50-milacre rectangle was downslope from the 25-milacre square. The staked 25. and 50-milacre plots were divided into strips 6.6 feet wide, making five strips shots in plots of various sizes; for each species, the frequency of occurrence in plots; for each of the several grass specie; the area covered or ground space of plants; and, for all species collectively, the estimated number of plants per unit of area and the available space per plant. Comparisons between pastured and unpastured hill prairie were made. From the data it was possible to construct a species-area curve and from the curve to find the sizes of certain reference areas, als will be explained later in this section.

llethod of Counting Plant Units.For plants other than grasses, each shoot that appeared above the ground surface and was without obvious connection to another shoot was counted as one unit, or individual. For example, each single rosette of Solidago nemoralis was counted as one individual; each shoot of Houstonin uigricans. Petalostemum purpureum. and Desmodium ciliare was counted as one individual unless connections with other shoots could be traced. 
For the three bunch grasses, Andropogon scoparius, A. gerardi, and Bouteloun curtipendula, the shoots that grew as individuals or in small bunches were counted and recorded. In the Phegley prairie, the shoots were small and mostly distinct and separate. In the Sampson prairie, the shoots were mostly aggregated into "tufts," and these into bunches of varying sizes. In this prairie, $A$. scoparius occurred also in several large patches within the plots. The number of shoots in such patches was estimated as follows: the average number of shoots per square inch in the smaller bunches was determined by counts; this number was multiplied by the number of square inches in each of the larger parches.

During later stages of preparation of this report, it was evident that an estimate of numbers of grass-plant individuals per unit of area could be of great value in finding average plant densities in hill prairies. Other workers have made such estimates. Steiger (1930), in his study of high and low prairies of Nebraska, apparently counted each occurrence, whether a single shoot or a bunch, as a grass-plant individual. From the quadrat maps in his report, the bunches of grass appear not so large as those in hill prairies in Illinois. Korstian \& Coile (1938), in a study of plant competition in forest stands, found the most densely covered forestAloor milacre had about 10 grass plants per 0.01 milacre. "Thus each 0.01 milacre occupied by a colony was regarded as fully stocked, even though it contained few or no individual plants." Neither Steiger's procedure nor the one followed by Korstian $\mathbb{A}$ Coile seemed adequate for Illinois hill prairies. The estimate of numbers of grass-plant individuals for these prairies was therefore made by at different method.

Two bunches of Andropogon scoparius were obtained, one from the Northeast Meredosia prairie, one from the basal slope at Reavis Spring prairie. Each bunch was taken from an unpastured prairie strip that was separated from the adjacent pastured prairie slopes by a fence. These bunches were carefully dissected to find how many shoots were connected by living stems in what might be considered as individual plants. For convenience, each aggregate of shoots considered to be an individual plant was called a tuft. Before separation, each bunch was mapped with a pantograph to show folitge area or crown cover, area at ground surface, location of solitary live shouts, and what appeared to be iggregates of shoots or "apparent tufts." (It was recognized that separation of a bunch into tufts might give very different results from those of the preliminary surface examination.) It was found that the average number of shoots per tuft of A. scoparius was 3.375 for the Northeast Meredosia sample and 3.793 for the one from Reavis Spring. The characteristic tuft (grass-plant individual) of $\%$ scoparius was found to be an aggregate of 3 or $t$ shoots, average 3.5 .

The same method was used by II. A. Moore and A. G. Vestal to determine the number of shoots per plant individual for Indropogon gerardi. In a clump of big bluestem, collected by Moore from a railroad trackway east of Urbana, Moore and I estal found by separation that the average number of shoots per tuft or grass plant was 1.739 . The characteristic tuft (grass-plant individual) of big bluestem consisted of 1 or 2 shoots, average 1.75 .

As a preliminary step in estimating the number of plants of Bouteloua curtipendula, the writer obtained a small sample from Mud Creek prairie and cirrefully dissected the bunches to determine the number of shoots per plant or tuft. It was found that the aserage number of shoots per tuft was $3 .+37$; the individual plant of B. curtipendula was an aggregation of 3 or + shoots, average 3.5 .

For each of the bunch-grass species, the estimated number of tufts in bunches was found by dividing the number of shoots in bunches by the average number of shoots per tuft, or hy a factor hased upon this average.

Density of Vegetation.- The measure of vegetation density in this study is the number of plants per milacre. 'The mapped central milacre of the Sampson and that of the Phegley prairie were used in determining density for this report.

Grasses.-In the central milacre of the Sampson prairie, 4,051 shoots of Andropogon scoparius grew in bunches and patches. The $t .051$ shoots formed an es- 
timated 1,157 grass-plant individuals or tufts. 'lhis estimate was reached by tividing the number of shoots in bunches and patches $(4,051)$ by the number of shoots in a typical tuft ( 3 or 4 , average $3.5)$. There were in addition 247 shoots not aggregated into tufts or hunches. These were considered individual plants, as it was impussible to determine any underground connections without digging and removing these shoots from the milacre. The estimated total number of individuals of $A$ scoparius was $1,+(04$.

In the Phegley prairie, the shoots of Andropogon scoparius were mostly short and well separated, with very litte laterat cxtension of the foliage. The open appearance of each bunch, the large proportion of hare ground, and the considerable ground area per shoot within the hunches were attributed to grazing and trampling by cows. Cows doubtess destroved many shoots either by pulling them out or breaking them off and thus materially reduced the number of shoots per tuft.

In the samples taken from ungrazed hill prairie in two sites, Northeast Meredosia and Reavis Spring, the number of shoots per tuft averaged between 3 and $t$. In the mapped central milacre of the pastured Phegley prairie, the number of shoots per tuft was not so large; it was conservative to place the number of shoots per tuft at one-half that of ungrazed prajrie, that is, 1.5 or 2.0 , average 1.75 . The $1.1+3$ shoots in bunches thus formed an estimated 653 tufts or grass-plant individuals. In addition, 196 isolated shoots, representing that many isolated plant individuals, were counted. 'The estimated total number of 1 . scoparius plants was $8+9$.

In the mapped Sampson milacre, 22 shoots of Adropogon gerardi were found; 19 of these occurred in one bunch. These 19 shoots formed 11 plant individuals (estimated). With the 3 isolated plants added, the estimated number of $A$. gerardi individuals was 1t. A. gerardi did not orcur in the mapped milace in the Pheg!ey prairie.

In the central milace of Sampson, 6 bunches of Bontelona curtipendula with +3 shoots were mapped. These 6 hunches contanined an estimated 12 plants. In addition, 32 isolated plants were counted. The estimated number of individuals of 13. curtipendula was 4 .

In the mapped Phegley milacre, 15 bunches of Bouteloua curtipendula with los shoots were charted. 'These 15 bunches contained an estimated 31 plants. In addition, 25 isolated plants were connted. The estimated number of individuals of $B$. curtipendula was 56 .

'The ungrazed Sampson prairie contained an estimated $1,+62$ grass plants in the centril milacre; the grazed Phegley prairie 905 in the central milacre. T'able 1 summarizes the above dati.

Plants Other Than Grasses.-Of plants other than grasses in the central milacre of Sampson prairie, 487 plants of

Table 1.- Shoot counts and estimated numbers of bunch-grass plant individuals in the mapped ceniral milacre of Sampson and of Phegley hill prairies.

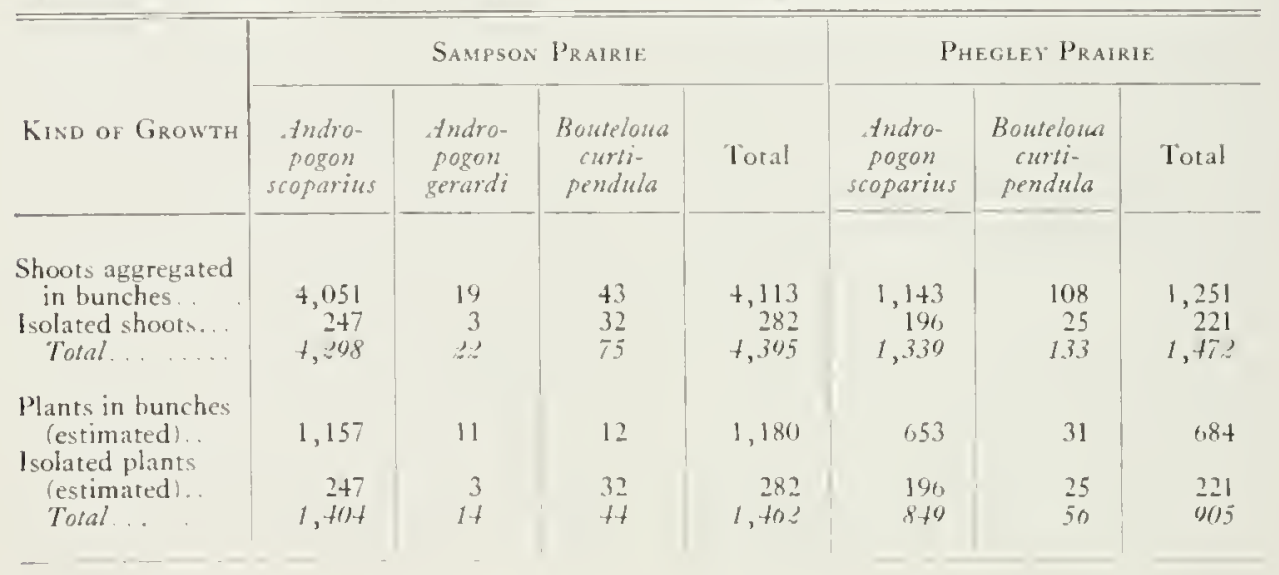


Table 2.-Species and numbers of plant in. dividuals in the central milacre of Sampson hill prairie.

\begin{tabular}{|c|c|}
\hline Species & $\begin{array}{c}\text { Singer of Plaxt } \\
\text { INDIVIDLALS }\end{array}$ \\
\hline 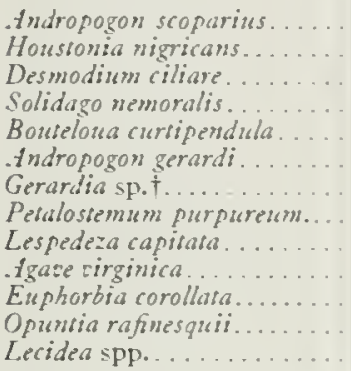 & $\begin{array}{c}404^{*} \\
1+1 \\
80 \\
64 \\
44^{*} \\
14^{*} \\
11 \\
9 \\
6 \\
2 \\
1 \\
1 \\
172^{*}\end{array}$ \\
\hline
\end{tabular}

- Estimated.

$\div$ Posibly G. gatlingeri.

10 different species were mapped and counted; in the central milacre of Phegley prairie, +36 plants of $1+$ species. Table 2 show density for both grass and nongrass species in the mapped Sampson milacre; table 3 gives similar information for species in the mapped Phegley milacre.

Total Densities.-In Sampson prairie, the density in the mapped central milacre was 1.949 plants; in Phegley, $1.3+1$.

In both prairies, grass-plant individua!s were more numerous than the nongrass plants. In Sampson, 75 per cent of the plant individuals were grasses and 25 per cent were not grasses; in Phegler, 67 per cent were grasses and 33 per cent were not. It is of interest that the nongrass species made up a higher percentage of the individual plants in grazed prairie than in ungrazed.

Ground Space of Plants.-Ground space of plants is considered here as the area occupied by the plants at ground sur-
Table 3.-Species and numbers of plant individuals in the central milacre of Phegley hill prairie.

\begin{tabular}{|c|c|}
\hline SPECIES & $\begin{array}{c}\text { Vimber OF Pl.AST } \\
\text { INDIVIDLALS }\end{array}$ \\
\hline 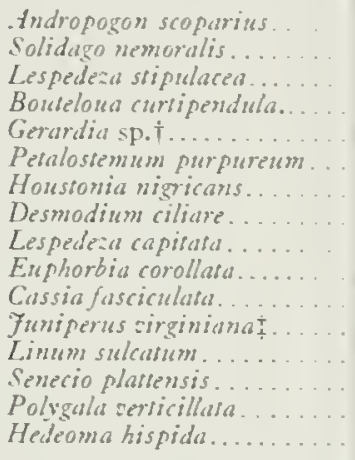 & $\begin{array}{l}8+9^{*} \\
270 \\
71 \\
56^{*} \\
29 \\
15 \\
13 \\
11 \\
8 \\
6 \\
4 \\
3 \\
3 \\
1 \\
1 \\
1\end{array}$ \\
\hline
\end{tabular}

* Estimated.

$\div$ Possibly G. gatringeri.

ț Small seedlings.

face. The writer determined the ground space for grasses, table $t$, from the maps of the central milacre of Phegles and Sampson prairies bs use of a planimeter.

Phegley Prairie.-1n the central milacre of this pastured prairie, Andropogon scoparius covered at ground level 1,107 square inches ( 71 square decimeters $*$, or $17.6+$ per cent of the milacre; Bouteloua curtipendula occupied $138 .+$ square inches (9 square decimeters), or 2.21 per cent of the milacre, tables $t$ and 6 . "The two bunch grasses covered 1,245.t square inches ( 80 square decimeters), or 19.85 per cent of the quadrat at ground level.

Most of the plants other than grasses. +37 individuals of $1+$ species, occurred in the spaces between the grass bunches. The

- Metric equivalents in this secton on kround space are given to the nearest whole number.

Table 4.-Ground space or areas (square inches) occupied al ground surface by the hunch grasses in the central milacre of Sampson and of Phe@ley hill prairies.

\begin{tabular}{|c|c|c|c|c|c|c|c|}
\hline \multirow[b]{2}{*}{$\begin{array}{c}\text { TyPe of PlaAt } \\
\text { GRowth }\end{array}$} & \multicolumn{4}{|c|}{ Sampson Prairie } & \multicolumn{3}{|c|}{ Phegley Prairie } \\
\hline & $\begin{array}{l}\text { Andro- } \\
\text { pogons } \\
\text { scoparius }\end{array}$ & $\begin{array}{l}\text { Andro- } \\
\text { pogon } \\
\text { gerardi }\end{array}$ & $\begin{array}{l}\text { Bouselous } \\
\text { curri- } \\
\text { pendula }\end{array}$ & Total & $\begin{array}{l}\text { Indro- } \\
\text { pogon } \\
\text { scoparius }\end{array}$ & $\begin{array}{l}\text { Bouseloun } \\
\text { curri: } \\
\text { pendula }\end{array}$ & Total \\
\hline $\begin{array}{l}\text { Bunches ......... } \\
\text { Isolated shoots... } \\
\text { Toral........ }\end{array}$ & $\begin{array}{r}1,6780 \\
1030 \\
1,7810\end{array}$ & $\begin{array}{r}87 \\
1.3 \\
100\end{array}$ & $\begin{array}{l}188 \\
10.5 \\
39.3\end{array}$ & $\begin{array}{r}1,7055 \\
11+8 \\
1,8 \geq 0.3\end{array}$ & $\begin{array}{r}9450 \\
1620 \\
1,1070\end{array}$ & $\begin{array}{r}112+ \\
260 \\
138+\end{array}$ & $\begin{array}{r}1,0574 \\
1880 \\
1,2454\end{array}$ \\
\hline
\end{tabular}


esimated ground space covered by these plants was 157.9 square inches, table 5 , an estimation computed in the following mamner. 'There were 29 rosettes of Solidayo memoralis that were clustered into five groups or patches. The five patche: occupied $36.5^{9}$ square inches in the central milacre. The remaining $2+1$ rosettes of this species were small and covered alout 0.5 square inch ealch, or a total of 120.5 square inches. 'The total ground suace of $s$. nemoralis for the milace was 157.09 spluare inches. "The remaining 167 individuals of 1.3 species were small and averaged only (o.0s inch (2 mm.) in dianceter, or $0.00+9$ suluare inch in areas. "The estimated ground space of these" plants was 0.82 spuare inch (167 $\mathrm{x}$ $\left.0.004^{(1)}\right)$. The extimated ground space for all the nongrass species was 157.9 spluare inche (10 syuare decinceters) or 2.52 per cent of the yuadrat, tahles 5 and 6 . The utal ground space for all plants in the central milacre at Ploceley prairic was $1,403.3$ square inches (9) square decimetersi, or 22.37 per cerlt of the quadrat. There remaned 4.869 .3 square inches, or 77.63 per cent of the quadrat, that was bave loess, tahles 5 and 6.

Sampson Prairie.-In the central milacre of this umpastured pratire. Andopo"on soporius covered 1,781 square inches (115 square decimeters), or 28.39 per cent of the milacre; Bruteloua curtipendula and 1 gorardi together occupied 39.3 square inches (3 square decimeters), or $(1.03$ per cent of the plot, tables $t$ and 6. The three bunch urasses covered at ground level $1,820.3$ spuare inches (117 square decimeters), or 29.02 per cent of the milacre.

The ground space for the remaining t87 plant individuals of 10 species was computed in the same manner as was the ground space for the plants in Pluegley. Lecidea, which grows over the surface of the loess, occupied 29.6 square inches of the milacre as computed from the map by use of a planimeter. The tgare and Opunita were each ahout 0.625 incl in diameter at the ground surface; the three plants occupied approximately a square inch. The $6+$ small rosettes of Solidago nemoralis covered 32.0 square inches $(6+\times 0.5)$. The remaining 248 plants,
Table 5.-Ground space or areas (square inches) occupied at ground surface by grass plants, plants other than grasses, and bare loess in the central milacre of Sampson and of Phegley prairies.

\begin{tabular}{|c|c|c|}
\hline IVIPE OF PI.ANT GROWIH & $\begin{array}{l}\text { SAMPSON } \\
\text { PralRIE }\end{array}$ & $\begin{array}{l}\text { PHEGLEY } \\
\text { PRAIRIE }\end{array}$ \\
\hline $\begin{array}{l}\text { Bunch grasses. .... } \\
\text { llangs other than grasses. } \\
\text { All plants. } \\
\text { Bare loess. }\end{array}$ & $\begin{array}{r}1,8203 \\
6,3.8 \\
1,884 \quad 1 \\
+, 3889\end{array}$ & $\begin{array}{r}1,245.4 \\
157.9 \\
1,403.3 \\
t, 860.3\end{array}$ \\
\hline
\end{tabular}

Table 6.- ler cent of the central milacre of Sampson and of Phegley hill prairies occupied at ground surface by bunch grasses, plants other than grasses, and bare loess.

\begin{tabular}{|c|c|c|}
\hline $\begin{array}{l}\text { SPECIES OR TiPE OF } \\
\text { P'LANT GRUWTH }\end{array}$ & $\begin{array}{l}\text { SAMPSON } \\
\text { PraIRIE }\end{array}$ & $\begin{array}{l}\text { PHEGLEY } \\
\text { PraIRIE }\end{array}$ \\
\hline 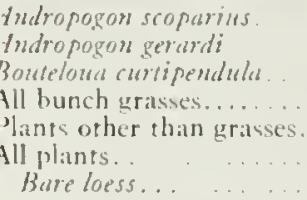 & $\begin{array}{rr}28 & 39 \\
0 & 16 \\
0 & 47 \\
29 & 02 \\
1 & 02 \\
30 & 04 \\
09 & 90\end{array}$ & $\begin{array}{r}17.64 \\
000 \\
2.21 \\
19.85 \\
2.52 \\
22.37 \\
77.03\end{array}$ \\
\hline
\end{tabular}

all small, covered 1.2 square inches. The nongrass species together wccupied 63.8 square inches ( $t$ sipuare decimeters), or 1.02 per cent of the quadrat, tables 5 and 6. The total ground space for the plants in this milacre of ungrazed prairie was $1,88+.1$ spuare inches (122 square decimeters), or $30.0+$ per cent of the charted area. There remained,+ 388.5 square inches or 69.96 per cent of the quadrat not occupied at ground level hy plants.

Foliage Area or Crown Cover.Foliage area, crown area, or crown cover is considered here as the area that would be mapped if the crowns of the plants were projected on the ground surface directly below. Although foliage area was not inapped in the field, it was estimated in the following manner.

In the Sampson prairie, Andropogon scoparius had a large foliage area, fig. 11. The aspect of this grass in Sampson was sinilar to its aspect at Northeast Meredosia, where a sample was collected for separation. Foliage area of this sample was mapped. A factor of approximately 2.7 was derived when foliage area of the sample was divided by its ground space. 


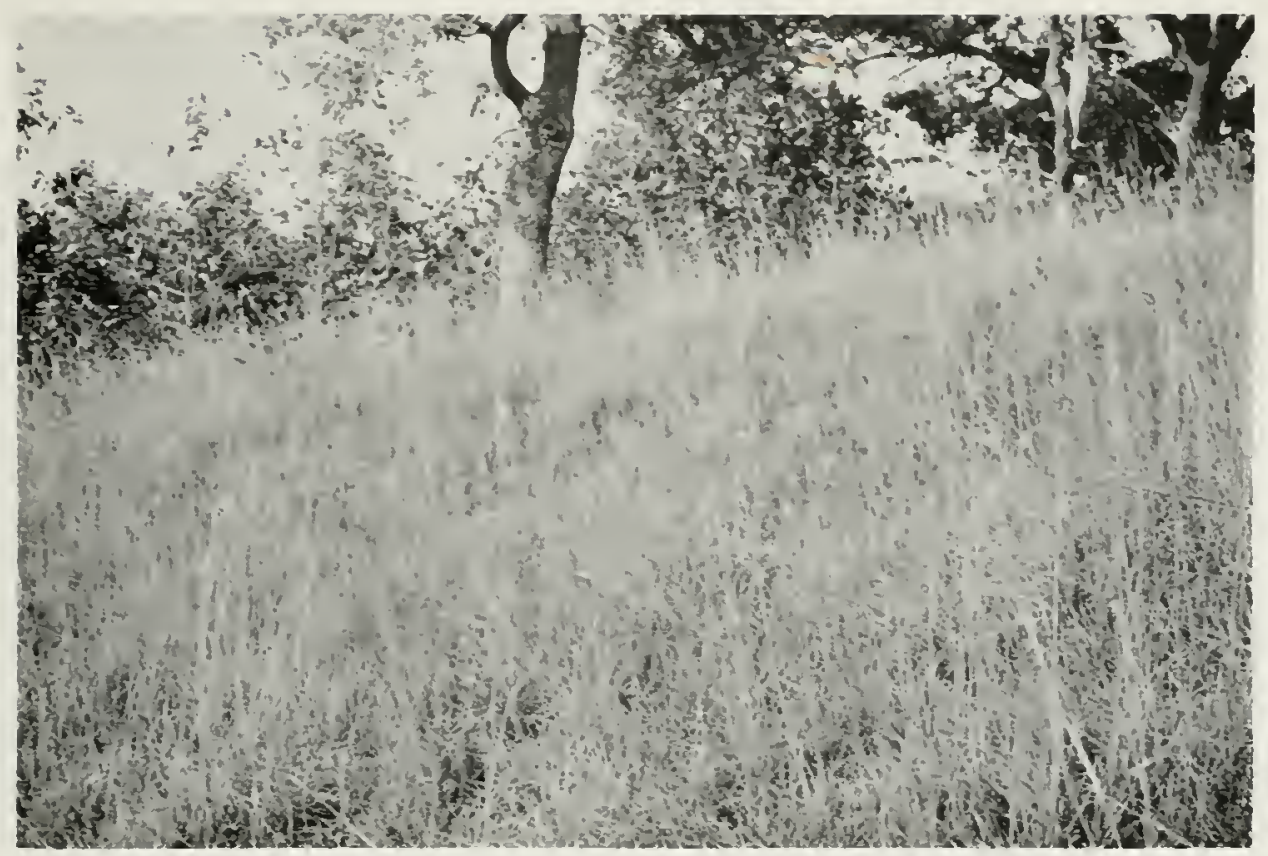

Fig. 11.- Copper spur slope in unpastuted Sampson hill prairie. The foliage area of the plants is much greater here than in the pastured Phegley prairie. Andropogon sioparius is the dominant grass: 1 . gerardi also is present. The above view is to the left (northwest) of plots -raked for vegetation studies of this report.

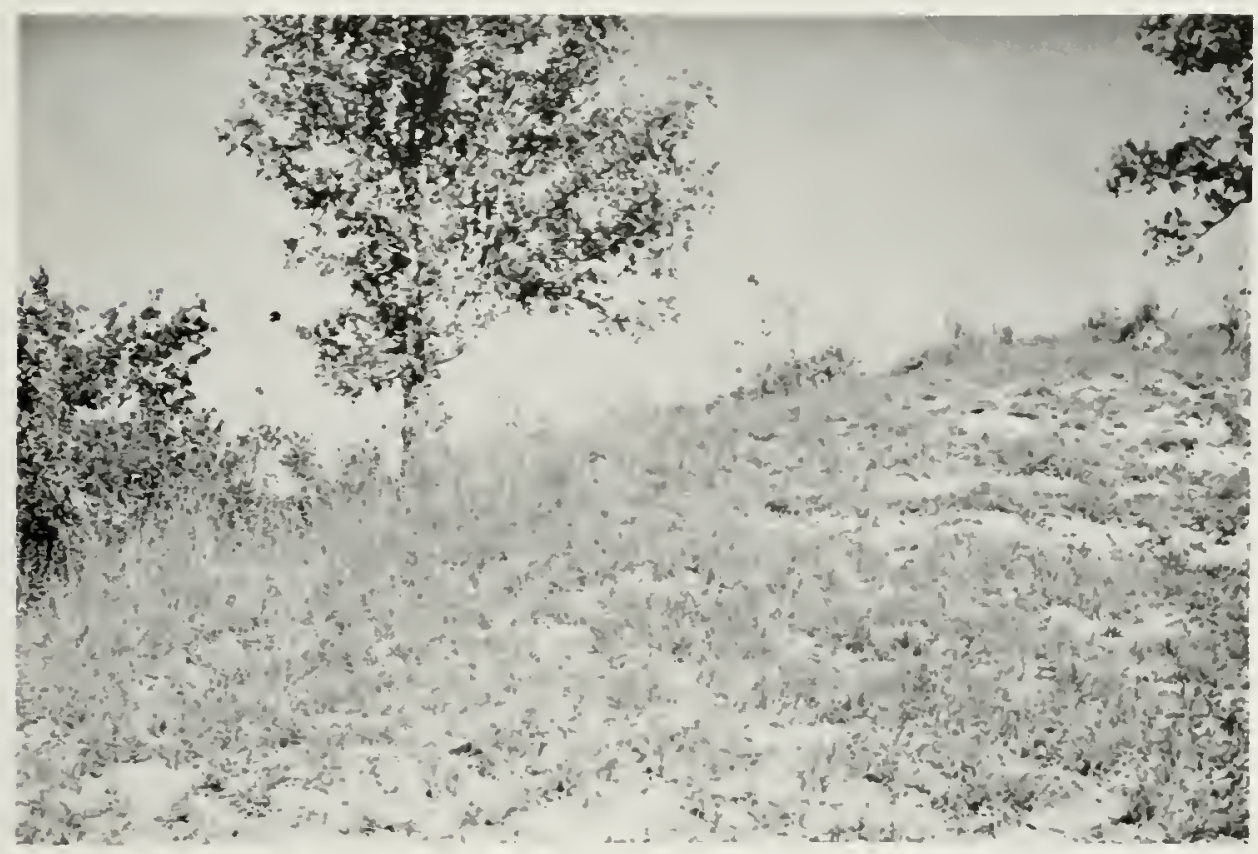

Fig. 12.- - Cpper spur slope in the pastured Phegley hill prairie. The foliage area of the plants is small. Androfogon sonparius is the dominani graw. Io the righe in the above view is a small part of some of the plots staked for the vegetation studies of this report. 
Table 7.-Foliage area (square inches) for plants in the central milacre of Sampson and of l'hegley hill prairies.

\begin{tabular}{|c|c|c|}
\hline $\begin{array}{c}\text { SPECIES UR TIPE of } \\
\text { PLAST CRROWTH }\end{array}$ & $\begin{array}{l}\text { SAMPSON } \\
\text { ['RA]R]E: }\end{array}$ & $\begin{array}{l}\text { P'HEGIIEY } \\
\text { P'KAIRIE }\end{array}$ \\
\hline 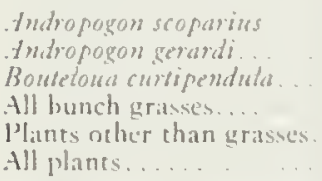 & $\begin{array}{r}+, 809 \\
27 \\
60 \\
+, 896 \\
92 \\
+, 988\end{array}$ & $\begin{array}{r}1,994 \\
0 \\
285 \\
2,279 \\
240 \\
2,525\end{array}$ \\
\hline
\end{tabular}

In order to estimate boliage areal of $\%$ scoperius in the central milacre of simpson, the writer multiplied the groundspace value of this grats he 2.7. "The same factor was used in order to estimate foliage area for $/$. gurardi. For boutclowa curtipendula, a factor of 2.06 was weel ; this figure was indicated by expararion of the sample Irom . Mud Creek prairie. The estimated foliage areat for all errass species in the central milace of Sampon was $\left.+8^{\circ}\right) 6$ spuare inches, table 7. For Soldaduge ronettes, growing on the surface of the soil. folliage area was assumbed on be the sime as ground space. The lichens, Leviden, are not included here as their thalli-simple plant bodies without true ronts, stems, or leavesarow under the toliage cover of other plants and thus do not contribute to foliage area. "The estimated follage area of tome and Opuntia was 10.35 square incles. For the remaining 251 plants. mostly secdlings or small plants, the foliage area was estimated at 0.2 square inch per plant. The aggregate foliage area of plants other than grasses was estimated to he 92 square inches. The total wtimated foliage area in the central milacre of the Sampon prairie was 4.988 square inches or 79.52 per cent of the milacre, tables 7 and 8 .

In the Phegley prairie, both in the central milacre and in the prairie as a whole, Andropogon scoparius showed obvious reduction of cover, fig. 12, both at ground level and at foliage levels as compared with this species in the unpastured prairie. The leaves covered an area larger than the ground space, but not sol large as the area covered by the leaves in the Sampon prairie. Foliage area for 1 sco-
Table 8.-Foliage area (per cent of total area) for plants in the central milacre of Sampson and of l'hedley hill prairies.

\begin{tabular}{|c|c|c|}
\hline $\begin{array}{l}\text { SPECJES OR TYYE OF } \\
\text { PLANT GROWTH }\end{array}$ & $\begin{array}{l}\text { SAMPSSOS } \\
\text { PrRAIRIE }\end{array}$ & $\begin{array}{l}\text { Phegles } \\
\text { Pratrie }\end{array}$ \\
\hline 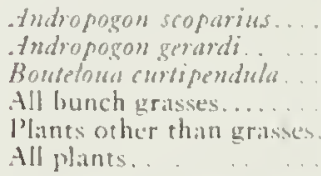 & $\begin{array}{rr}70 & 60 \\
0 & 43 \\
0 & 96 \\
78 & 05 \\
1 & 47 \\
79 & 52\end{array}$ & 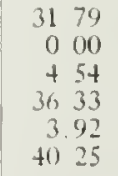 \\
\hline
\end{tabular}

parius in the central milacre of the Phegley prairie was estimated at 1.8 times the ground space; this factor multiplied by the grouml space gave an algeregate folbige area of $1,99+$ stuare inches, tahle 7 . For Bouteloua curtiposdula, the factor 2.06 was again werl (as in Sampson), which gave for this species in Plegley an estimated follage area of 285 souare incless. Plants of lespedeza stipulacen, witls an estimated follage area of 1.5 syuare incles per plant, had an estimated aggregate area of 106 symare inches. For prostrate rosettes of Sollidag", the folliage area was comsidered to be ecjuivalent to ground space (as in Sampsorn). For the remaining plants, all snall and mostly scedlings, foliage area was estimated at 0.2 square inch per plant. Plants other than grasies had an estimated aggregate foliage area of $2+6$ sipuare inches. The total estimated foliage area in the central milacre of the Pheyley prairie was 2.525 square inches, or +0.25 per cent of the milacre, tables 7 and 8.

Available Space per l'lant.-Avail. able space per plant, the inverse of plant density, is another character that, like density, can be useful in descriptions and comparisons of regetation. It is simply ohtained by dividing the area of the measured sample by the number of plants in it.

Variahles affecting available space nes plant are size of plants, degree of crowding, and percentage of the measured area covered by plants. In those vegetations which show great disparity in sizes of plants of different species, as sagehrush with short-grass, average available space ner plant should be separately found for each component or laver. In the Illinosic hill prairies studied, individuals of the 
Table 9.-Available space per plant in the central milacre of Sampson and of Phegley hill prairies.

\begin{tabular}{|c|c|c|c|c|}
\hline \multirow{2}{*}{ Hilol Prairie } & \multirow{2}{*}{$\begin{array}{l}\text { ArEa OF MILACRE } \\
\text { IN SQUARE INCHES }\end{array}$} & \multirow{2}{*}{$\begin{array}{l}\text { NiMBBER OF } \\
\text { PLANTS }\end{array}$} & \multicolumn{2}{|c|}{ AVAlLABLE SPaCE PER l'LANT } \\
\hline & & & Square Inches & Square Centimeters \\
\hline $\begin{array}{l}\text { Sampson . . . . . . . } \\
\text { Phegley . . . . . }\end{array}$ & $\begin{array}{l}6,272.64 \\
6,272.64\end{array}$ & $\begin{array}{l}1,949 \\
1,341\end{array}$ & $\begin{array}{l}3.22 \\
4.68\end{array}$ & $\begin{array}{l}20.77 \\
30.19\end{array}$ \\
\hline
\end{tabular}

three bunch-grass specics are not so different in size from the plants of most other herb species (most of them dicotyledons) as to call for separate estimations of arailable space for grasses and for other herbs.

Available space per plant for Sampson and Phegley hill prairics is given in table 9.

Numbers of Plant Species for Various Plot Sizes.-From the species lists compiled for plot sizes ranging from 164 milacre to 75 milacres, it was possible to find the average number of plant species in plots of several sizes and also the increase in number of species with an increase in area.

Sampson Prairie.- In the central milacre of the Sampson prairic, for plots of 16 -milacre size the average number of species was 3.79 , the average number of individuals, 30.t5. One of the plots of this size contained but one species, Andropoyon scoparius; the plot with the greatest number of species contained seven, Andropogon scoparius, Solidago nemoralis, Honstonia nigricans. Desmodium ciliare, Bouteloua curtipendula. Agare zirginica, and Lecidea sp.

Plots of 1/16-milacre size in the central milacre contained 3 to 10 species each and averaged 6.56 per plot; the number of plants averaged 121.81. Quadrats of 1 t-milacre size in this milacre contained 7 to 11 species each and averaged 9.5 per plot; the average number of plants was +87.25 .

In the 9-milacre square, the species list compiled by 1/t-milacre units showed a range of 5 to 11 species and an average of 7.33 per unit; plots of the 1-milacre size had 9. to 13 species each and averaged 11.22. In the 9-milacre square, a total of 18 species was found. Species not found in the central milacre but found in one or more of the $S$ milacres surrounding it were Senecio plattensis, Carya sp. (scedling), Aster patens. Sistrinchium albidum, and an mudentified moss.

The 9-milacre plot formed a part of the staked 25-milacre square. Species lists were made for the 25-milace quadrat by 5-milace strips. "1hree species, Jumiperus zirginiana, Kulluia enpatorioides, and Helianthus dizaricatus, not found in the 9-milacre plot, were found in other parts of the 25-milacre yuadrat, and brought the total to 21 species for the 25-milacre quadrat.

The 50-milacre rectangle, fig. 10 downslope from the 25-milacre guadrat was checked by 10-milacre strips. Twenty species were found in this 50 -milace area. Three species, Ister oblongifolius, Elymus canadensis, and Eupatorium allissi$m u m$, found here were not found in the 25-milacre unit. However, the species of Carya. Opuntia, Sisyrinchium, and Itelianthus found within the 25-milacre square were absent from the larger area. In the 75-mibare area, $2+$ species were present.

Phegley Prairie. In the central milacre of the Phegley prairie, for plots of 1/6t-milacre size the average number of species was 3.94 , the average number of plants, 20.95. In one of the p!ots of this size only one species, Androposon scoparius, with two individuals, was foumd; the plot with the greatest number of species contaned eight, A. scoparius, Solidago nemoralis, Houstunia nigricans, Gerardia sp. (possibly G. gattingeri), Lespedeza stipulacea, Bouteloua curtipendula. Euphorbia cromollata, and $L$. crpitata.

Plots of 1 16-milace size in the colytral milace contained + to 11 species each and averaged 7.13 per plot. The number of plants in plots of this size areraged 83.81. Qualrats of 1 t-milacre size in this milacre contained 11 or 12 species 
each and averaged 11.5. "The average number of plants was 335.25 in this size unit.

In the 9-milacre square, the species list compiled by 1 t-milacre units showed a range of 6 to 12 species and an average of 9.27 per unit. The 1 -milacre plot size had a range of 11 to 16 species each and an average of 13.tt. 'l'en species not found in the central milate but found in the surrounding eight were Indrofogon gerardi, Le'ciden sp., dster pate'ns, fragrosis spectabilis, Rhus cepallina, Kuhuia cupatorioides, f'anicum serilmerianum. Pou pratensis, Ruellin humilis, and a second species of Gerardin (posihly ( $B$. nspera). Twenty-sis were found in the 9-milacre yuadrat.

The 9-milacie plot formed a part of the staked 50-milacre rectangle, fig. ](), which was esanined by folmilace strip. Six species not found in the 9-milacre square were found in other parts of the rectangle. 'These were Aster oblongicolius, () puntia rafinesquii, Tridens flaqus. Jelitotus allow. Rhus aromatica, and Erigeron strigosus. The first four of these were found only in the 10 -milace strip nearest the improved pasture eastward from the crest of the ridge. "This strip, because of its proximity to the pasture, probably should not be considered typical hill prairie. 'I"wo species not found in the 1)-milacre plot were found in other parts of the four downslope 10-milace strips and brought the total to 28 species.

"1he" 25-milace quadrat downslope from the 50-milacre rectangle siclded but one species that did not oceur in the 50 milacre rectangle; this was Isclepins riridiflora. "There were, however, severn species in the four downslope J0-milacre itrips of the 50-milacte areal that did not wecur in the 25-milacre unit. "These were Khus copallina, Kuhnia eupatorioilles. l'micum scribueriamum, Pon prasensis, prairie.

Tahle 10.- firequency of oceurrence of plant species in plots of five sizes, Sampson hill

\begin{tabular}{|c|c|c|c|c|c|c|c|c|c|c|}
\hline \multirow[t]{2}{*}{ SPERTES } & \multicolumn{2}{|c|}{$\begin{array}{c}\text { SIZE. A } \\
1256 \\
\text { MILACRE, } \\
00156, \\
\text { SIIARE } \\
\text { MrIER) }\end{array}$} & \multicolumn{2}{|c|}{$\begin{array}{l}\text { SIZE I3 } \\
1 \text { t.4 } \\
\text { III.ACRI, } \\
\text { () OW } 25 \\
\text { SIIARI } \\
\text { METFR }\end{array}$} & \multicolumn{2}{|c|}{$\begin{array}{l}\text { SI\%F C } \\
\text { (I } 1 \% \\
\text { IIIACKF, } \\
\text { O) } 25 \\
\text { SUL IRE } \\
\text { MIFIER! }\end{array}$} & \multicolumn{2}{|c|}{$\begin{array}{c}\text { SIZE I) } \\
(14 \\
\text { MIIACRE, } \\
1 \text { OI } \\
\text { SRIARE } \\
\text { MITER }\end{array}$} & \multicolumn{2}{|c|}{ 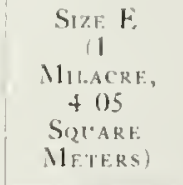 } \\
\hline & $\begin{array}{c}\text { Sum- } \\
\text { ber } \\
\text { ot } \\
\text { Plots }\end{array}$ & $\begin{array}{l}\text { Per } \\
\text { Cent } \\
\text { of } \\
\text { Piots }\end{array}$ & $\begin{array}{c}\text { Sum- } \\
\text { ber } \\
\text { of } \\
\text { plots }\end{array}$ & $\begin{array}{l}\text { Per } \\
\text { Cent } \\
\text { of } \\
\text { Plor }\end{array}$ & $\begin{array}{c}\text { Sum- } \\
\text { loer } \\
\text { of } \\
\text { Plots }\end{array}$ & $\begin{array}{c}\text { Per } \\
\text { Cent } \\
\text { of } \\
\text { Plots }\end{array}$ & $\begin{array}{c}\text { Yum } \\
\text { ber } \\
\text { of } \\
\text { Plots }\end{array}$ & $\begin{array}{l}\text { Per } \\
\text { Cent } \\
\text { of } \\
\text { plots }\end{array}$ & $\begin{array}{l}\text { Num. } \\
\text { her } \\
\text { of } \\
\text { plots }\end{array}$ & $\begin{array}{l}\text { Pet } \\
\text { Cent } \\
\text { of } \\
\text { Plots }\end{array}$ \\
\hline 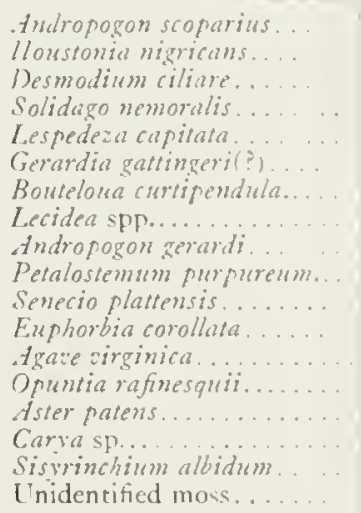 & $\begin{array}{r}60 \\
22 \\
14 \\
13 \\
1 \\
1 \\
12 \\
4 \\
1 \\
- \\
- \\
-\end{array}$ & $\begin{array}{rr}93 & 8 \\
34 & 4 \\
20 & 7 \\
20 & 3 \\
1 & 6 \\
1 & 6 \\
18 & 5 \\
6 & 3 \\
1 & 6 \\
- \\
- \\
3 & 1 \\
- \\
-\end{array}$ & $\begin{array}{r}64 \\
49 \\
42 \\
32 \\
5 \\
11 \\
17 \\
8 \\
3 \\
8 \\
1 \\
2 \\
1 \\
- \\
- \\
\end{array}$ & $\begin{array}{rl}100 & 0 \\
78 & 1 \\
65 & 6 \\
50 & 0 \\
7 & 8 \\
17 & 2 \\
26 & 6 \\
12 & 5 \\
4 & 7 \\
12 & 5 \\
- \\
1 & 6 \\
3 & 1 \\
1 & 6 \\
- & \end{array}$ & $\begin{array}{l}16 \\
15 \\
16 \\
15 \\
5 \\
8 \\
9 \\
8 \\
2 \\
7 \\
1 \\
2 \\
1 \\
- \\
-\end{array}$ & $\begin{array}{rr}100 & 0 \\
9.3 & 8 \\
100 & 0 \\
9.3 & 8 \\
31 & 3 \\
50 & 0 \\
56 & 3 \\
50 & 0 \\
12 & 5 \\
43 & 8 \\
- \\
6 & 3 \\
12 & 5 \\
6 & 3 \\
- \\
- \\
-\end{array}$ & $\begin{array}{l}36 \\
36 \\
33 \\
33 \\
24 \\
20 \\
18 \\
15 \\
14 \\
13 \\
7 \\
7 \\
2 \\
2 \\
1 \\
1 \\
1 \\
1\end{array}$ & 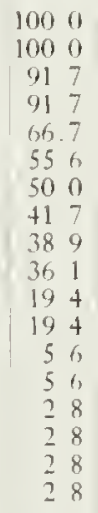 & $\begin{array}{l}9 \\
9 \\
9 \\
4 \\
9 \\
9 \\
8 \\
7 \\
6 \\
7 \\
4 \\
5 \\
2 \\
2 \\
1 \\
1 \\
1 \\
1\end{array}$ & $\begin{array}{rr}100 & 0 \\
100 & 0 \\
100 & 0 \\
100 & 0 \\
100 & 0 \\
100 & 0 \\
88 & 9 \\
77 & 8 \\
66 & 7 \\
77 & 8 \\
44 & 4 \\
55 & 6 \\
22 & 2 \\
22 & 2 \\
11 & 1 \\
11 & 1 \\
11 & 1 \\
11 & 1\end{array}$ \\
\hline
\end{tabular}


Hedeoma hispida, R. aromatica, and Gerardia (possibly G. aspera). The T5-milacre unit minus the 10-milacre horder strip contained 29 species. The 75-milacre unit contained 33 species.

Frequency of Occurrence of Species.-The frequencr, or repeated occurrence, of plant species in Phegley and Sampson prairies was determined trom species lists of each of the following plot sizes: 1 256-, $164-, 116-, 1 / t-$, and 1-milacre. Although the 1 256-milacre unit was not marked in the field, data for plots of this size were obtained from maps of the mapped central milacre of both Sampson and Phegley prairies, figs. $S$ and 9. On such maps the northwest quarter of the milacre was divided intu $6+$ equal quadrats and, from these, species lists were compiled. The metric equiralent of this quadrat size is 0.0156 square meter. For an! given plot size the frequency was expressed as a percentage computed hy dividing the number of quadrats in which the species occurred by the total number of quadrats of that size employed.

Sampson Prairie.- Table 10 summarizes the data for the frequency study in unpastured Sampson prairie. It is evident that the 1 256-milacre size was too small for use in ecological studies of Illinois hill prairies; only one species. indropogon scoparius, attained a high percentage of occurrence. The 16 t-milacre prairie.

Table 11.-Frequency of occurrence of plant species in plots of five sizes, Pheøles hill

\begin{tabular}{|c|c|c|c|c|c|c|c|c|c|c|}
\hline \multirow[t]{2}{*}{ SPECIES } & \multicolumn{2}{|c|}{$\begin{array}{c}\text { SIZE A } \\
1256 \\
\text { MILACRE. } \\
0.0156 \\
\text { SQ(ARE } \\
\text { METER) }\end{array}$} & \multicolumn{2}{|c|}{$\begin{array}{c}\text { SIZE B } \\
11 \text { of } \\
\text { MILACRE. } \\
00025 \\
\text { SULARE } \\
\text { MIETER) }\end{array}$} & \multicolumn{2}{|c|}{$\begin{array}{c}\text { SIzE C } \\
116 \\
\text { MILACRE, } \\
025 \\
\text { SQLARE } \\
\text { METER }\end{array}$} & \multicolumn{2}{|c|}{$\begin{array}{c}\text { SIZE D } \\
11+ \\
\text { MILACRE. } \\
101 \\
\text { SRLARE. } \\
\text { MetFRS, }\end{array}$} & \multicolumn{2}{|c|}{$\begin{array}{c}\text { SIzE F } \\
\text { I } \\
\text { MILACRE, } \\
+05 \\
\text { SUIARE } \\
\text { Meter }\end{array}$} \\
\hline & $\begin{array}{c}\text { Dum- } \\
\text { ber } \\
\text { of } \\
\text { Plots }\end{array}$ & $\begin{array}{c}\text { Per } \\
\text { Cent } \\
\text { of } \\
\text { Plots }\end{array}$ & $\begin{array}{c}\text { Sum- } \\
\text { ber } \\
\text { of } \\
\text { plot }\end{array}$ & $\begin{array}{c}\text { Per } \\
\text { Cent } \\
\text { of } \\
\text { Plots }\end{array}$ & $\begin{array}{c}\text { Yum- } \\
\text { ber } \\
\text { of } \\
\text { Plots }\end{array}$ & $\begin{array}{c}\text { Per } \\
\text { Cent } \\
\text { of } \\
\text { Plots }\end{array}$ & $\begin{array}{c}\text { Vum- } \\
\text { ber } \\
\text { of } \\
\text { Plots }\end{array}$ & $\begin{array}{c}\text { Per } \\
\text { Cent } \\
\text { of } \\
\text { Plots }\end{array}$ & $\begin{array}{l}\text { Dum- } \\
\text { ber } \\
\text { of } \\
\text { plots }\end{array}$ & $\begin{array}{c}\text { Per } \\
\text { Cent } \\
\text { ot } \\
\text { Plots }\end{array}$ \\
\hline 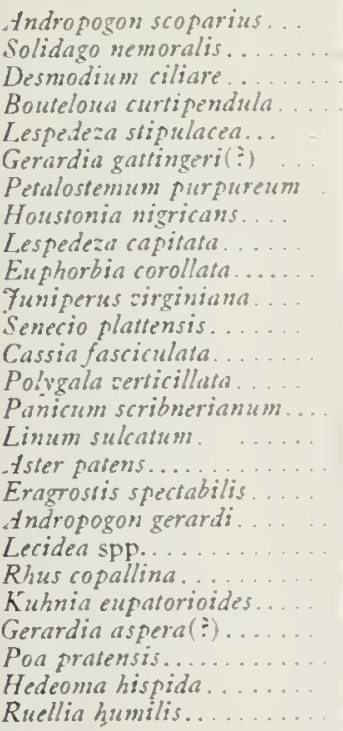 & $\begin{array}{r}57 \\
42 \\
2 \\
3 \\
3 \\
9 \\
3 \\
3 \\
1 \\
3 \\
- \\
- \\
-1 \\
- \\
- \\
- \\
- \\
- \\
-\end{array}$ & 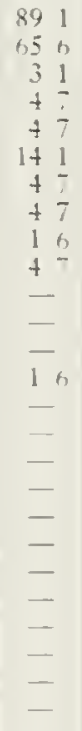 & $\begin{array}{r}64 \\
59 \\
8 \\
21 \\
29 \\
21 \\
13 \\
11 \\
7 \\
6 \\
3 \\
1 \\
3 \\
2 \\
3 \\
- \\
- \\
- \\
- \\
- \\
-\end{array}$ & $\begin{array}{rl}100 & 0 \\
92 & 2 \\
12 & 5 \\
32 & 8 \\
45 & 3 \\
32 & 8 \\
20 & 3 \\
1 & 2 \\
10.9 \\
9 \\
4 \\
1 \\
+7 \\
3 & 1 \\
- & 7 \\
- \\
- \\
- \\
- \\
-\end{array}$ & $\begin{array}{l}16 \\
16 \\
6 \\
9 \\
12 \\
13 \\
10 \\
10 \\
6 \\
5 \\
2 \\
1 \\
2 \\
2 \\
-3 \\
- \\
- \\
- \\
- \\
- \\
-\end{array}$ & $\begin{array}{rl}100 & 0 \\
100 & 0 \\
37 & 5 \\
56 & 3 \\
75 & 0 \\
81 & 3 \\
62 & 5 \\
62 & 5 \\
3 & 5 \\
31 & 3 \\
12 & 5 \\
6 & 3 \\
12 & 5 \\
12 & 5 \\
19 & 4 \\
- \\
- \\
- \\
- \\
-\end{array}$ & $\begin{array}{l}36 \\
36 \\
33 \\
33 \\
31 \\
30 \\
29 \\
2- \\
18 \\
11 \\
10 \\
9 \\
7 \\
4 \\
4 \\
3 \\
3 \\
2 \\
1 \\
1 \\
1 \\
1 \\
1 \\
1 \\
1 \\
1\end{array}$ & $\begin{array}{rl}100 & 0 \\
100 & 0 \\
91 & 6 \\
91 & 6 \\
86 & 1 \\
88 & 3 \\
80 & 6 \\
75 & 0 \\
50 & 0 \\
30 & 6 \\
27 & 8 \\
25 & 0 \\
19 & 4 \\
11 & 1 \\
11 & 1 \\
8 & 5 \\
8 & 5 \\
5 & 6 \\
2 & 8 \\
2 & 8 \\
2 & 8 \\
2 & 8 \\
2 & 8 \\
2 & 8 \\
2 & 8 \\
2 & 8\end{array}$ & $\begin{array}{l}9 \\
9 \\
9 \\
9 \\
9 \\
9 \\
9 \\
9 \\
7 \\
5 \\
6 \\
7 \\
4 \\
3 \\
3 \\
2 \\
2 \\
2 \\
1 \\
1 \\
1 \\
1 \\
1 \\
1 \\
1 \\
1\end{array}$ & $\begin{array}{ll}100 & 0 \\
100 & 0 \\
100 & 0 \\
100 & 0 \\
100 & 0 \\
100 & 0 \\
100 & 11 \\
100 & 0 \\
- & 8 \\
55 & 6 \\
46 & 2 \\
75 & 8 \\
44 & 4 \\
33 & 3 \\
33 & 3 \\
22 & 2 \\
22 & 2 \\
22 & 2 \\
11 & 1 \\
11 & 1 \\
11 & 1 \\
11 & 1 \\
11 & 1 \\
11 & 1 \\
11 & 1 \\
11 & 1\end{array}$ \\
\hline & $\begin{array}{l}115 \\
6+1\end{array}$ & $\begin{array}{l}i 25 \\
t s\end{array}$ & $\begin{array}{l}15 \\
5+\mathrm{p}\end{array}$ & $\begin{array}{l}\text { hecies } \\
\text { lots }\end{array}$ & $\begin{array}{l}1551 \\
16 \mathrm{~F}\end{array}$ & $\begin{array}{l}\text { cies } \\
\text { oit }\end{array}$ & $\begin{array}{l}=0 \\
\text { in } 1\end{array}$ & $\begin{array}{l}\text { ries } \\
\text { t. }\end{array}$ & ?n & ies \\
\hline
\end{tabular}


size in Sampson was more nearly adequate than the I 256-milacre size in this unpastured prairie; $t$ species of the 13 found in the $6+$ plots of the 1 ot-milacre size attained an percentage of 50 or more. These t species represented 30.77 per cent of the number of species found in the $6+$ plots. .1. scoparius occurred in all the quadrats of the 1 ot-milacre size. It is evident that the 1 16-and the 1/t-milacre plots ( $C$ and 1$)$ in table $J 0$ ) gave good

\section{Frequency Values for Combina-} tions of Species.-In Sampson and Phegley prairies, certain species of plants occurred together in so many plots as to call attention to the combinations. In Sampson, the species in combination were Andropogon scoparius, Solidago nemoralis, Houstoniu nigricans, and Desmodium ciliare. In Phegley, they were Andropogon scoparius, Solidngo nemoralis, Desmodium ciliare, and Bouteloua curtipendula. 'The

Table 12.- lirequency of occurrence of characteristic combinarions of plant species, Sampson and l'legley hill prairies.

\begin{tabular}{|c|c|c|c|c|c|}
\hline \multirow[b]{2}{*}{$\begin{array}{c}\text { NivBer } \\
\text { OF } \\
\text { QIUARRATs }\end{array}$} & \multirow[b]{2}{*}{$\begin{array}{c}\text { SIZE } \\
\text { OF } \\
\text { (I) ADRAT: }\end{array}$} & \multicolumn{2}{|c|}{ Savpson Combinatgon * } & \multicolumn{2}{|c|}{ Phegl.fy Combination $†$} \\
\hline & & $\begin{array}{l}\text { Number of } \\
\text { Occurrences }\end{array}$ & $\begin{array}{l}\text { Per Cent ot } \\
\text { Oecurrence }\end{array}$ & $\begin{array}{l}\text { Number of } \\
\text { Occurrences }\end{array}$ & $\begin{array}{l}\text { Per Cent of } \\
\text { Occurrence }\end{array}$ \\
\hline $\begin{array}{l}9 \\
36 \\
16 \\
64 \\
64\end{array}$ & $\begin{array}{ll}1 \\
1 & 4 \\
1 & 16 \\
1 & 64 \\
1 & 256\end{array}$ & $\begin{array}{r}9 \\
31 \\
15 \\
19 \\
2\end{array}$ & $\begin{array}{r}1000 \\
795 \\
93.8 \\
297 \\
3.2\end{array}$ & $\begin{array}{r}9 \\
30 \\
2 \\
1 \\
0\end{array}$ & 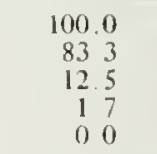 \\
\hline
\end{tabular}

- Combenacion in Sampon hill prairie: Indropogon scaparius Sulidago nemoralis, Houstania nigricans, and Desmodium ciliare.

$\rightarrow$ Combination in Phepley hill prairic: Indropogon scoparus, Soldago nemoralus, Desmodium cilsare, and Bouldoua curlipendula.

distribution annong specios. In the one (C). with a small number of plots and 13 species, 7, or 53.85 per cent, attained a percentage of 50 or more; in the other (D), with a large number of plots and 18 species, 7 , or 38.88 per cent attained a percentage of 50 or more. In Sampon prairie, the ireguency study showed, plots of $16+$ to $1 / t$ milacre were of sufficient size to give a satisfactory distribution of species.

Phegley Prairie.-Table 11 summarizes the data for the frequency study in pastured Phegley prairie. As in Sampson, the 1 250-milacre size was much too small to give good distribution; only $A n$ dropogon scoparius attained a high freyuency percentage. The I 6 t-milacre size did not give good distribution of species; only two, A. scoparius and Solidago nemoralis, attained percentages of 50 or more. These species represented 13.33 per cent of the total found in the $6+$ plots of this size. In Phegley prairie, the frequency study showed, plots of $1 / 16$ to $1 / t$ milacre were of sufficient size to give a satisfactory distribution of species. freguenct values for these combinations of species are summarized in table 12. For the two larger plot sizes, $1 / t$ and 1 milacre, the sample was the 9-milacre spuare. lior the $16+$ - and 1/16-milacre sizes, the sample was the central milacre of the 9-milacre spuare. For the 1 256-milacre size, the sample was $1 / t$ milacre, the northwest quarter of the central milacre. If the I t-milacre size had been studied in only the contral milacres, the percentage of uccurrence of the characteristic combinations for both Sampson and Phegley would have heen 100 .

Wherever one or more combinations of species can he discerned in any particular type of vegetation, the combinations can serve as a criterion of adequacy of plot size. In Phegley prairie, the 1/16-milacre size was obviously too small to give a fairly high frequency of occurrence for the characteristic combination; in Sampson prairie, the 1/6t-milacre size was too small.

Frequency of occurrence of characteristic combinations of species has been used as a test of the adequacy of size of sam- 
ple in one study known to the writer: the forest study by Vestal \& Heermans (19+5).

Species-Area Curve.-A species-area curve can he constructed from data obtained from the species list for the various plot sizes. The maps of the central milacres, figs. 8 and 9 , furnished the data for deriving average numbers of species in quadrats of 1 256-, 1/6t-, and 1/16-milacre sizes. Species lists, compiled by 1 tmilacre units, for each of the 9-milacre squares furnished the data for computing the averages for quadrats of $1 / t$ - and 1 milacre sizes. The total number of species found in the 9-, 25-, t0-, 50-, 65-, and 75 -milacre areas provided the figures for the larger plot sizes. These data are shown in table 13.

When the data are plotted on semilogarithmic paper, the resulting curves are S-shaped, fig. 13. From this type of curve. certain reference areas can be determined with the method described by lestal (19491. These are (1) the smallest representative area, (2) the minimum area for assigmment to type, after this referred to briefly as minimum area, and (3) the
Table 13.-Numbers of plant species in plots of various sizes, Sampson and Phegley hill prairies.

\begin{tabular}{|c|c|c|}
\hline \multirow{2}{*}{ Plut Size, Milacres } & \multicolumn{2}{|c|}{ Nisabrof Slectes* } \\
\hline & $\begin{array}{l}\text { Saypson } \\
\text { Prairie }\end{array}$ & $\begin{array}{l}\text { PHEGIEY } \\
\text { PraIRIE }\end{array}$ \\
\hline 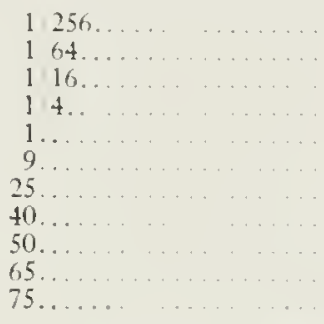 & $\begin{array}{r}2.11 \\
3.79 \\
6.56 \\
7.33 \\
1122 \\
18.0 \\
210 \\
200 \\
2+0\end{array}$ & $\begin{array}{rr}1 & 98 \\
3 & 94 \\
7 & 13 \\
9 & 27 \\
13 & 44 \\
26 & 0 \\
20 & 0 \\
28 & 0 \\
29 & 0 \\
-\end{array}$ \\
\hline
\end{tabular}

- The average number of species per quadrat fur plot sizes of 1 milacre and smaller: total number of species in largeı ginadiats.

area of fair-sized stand. The smallest representative area $(\mathrm{Ar})$ is the smallest onepiece area having some claim to he representative. It is the effective plot-size of Vestal \& Heermans (19+5). The mininum area $(\mathrm{Am})$, a plot-size that is large enough to include all the important

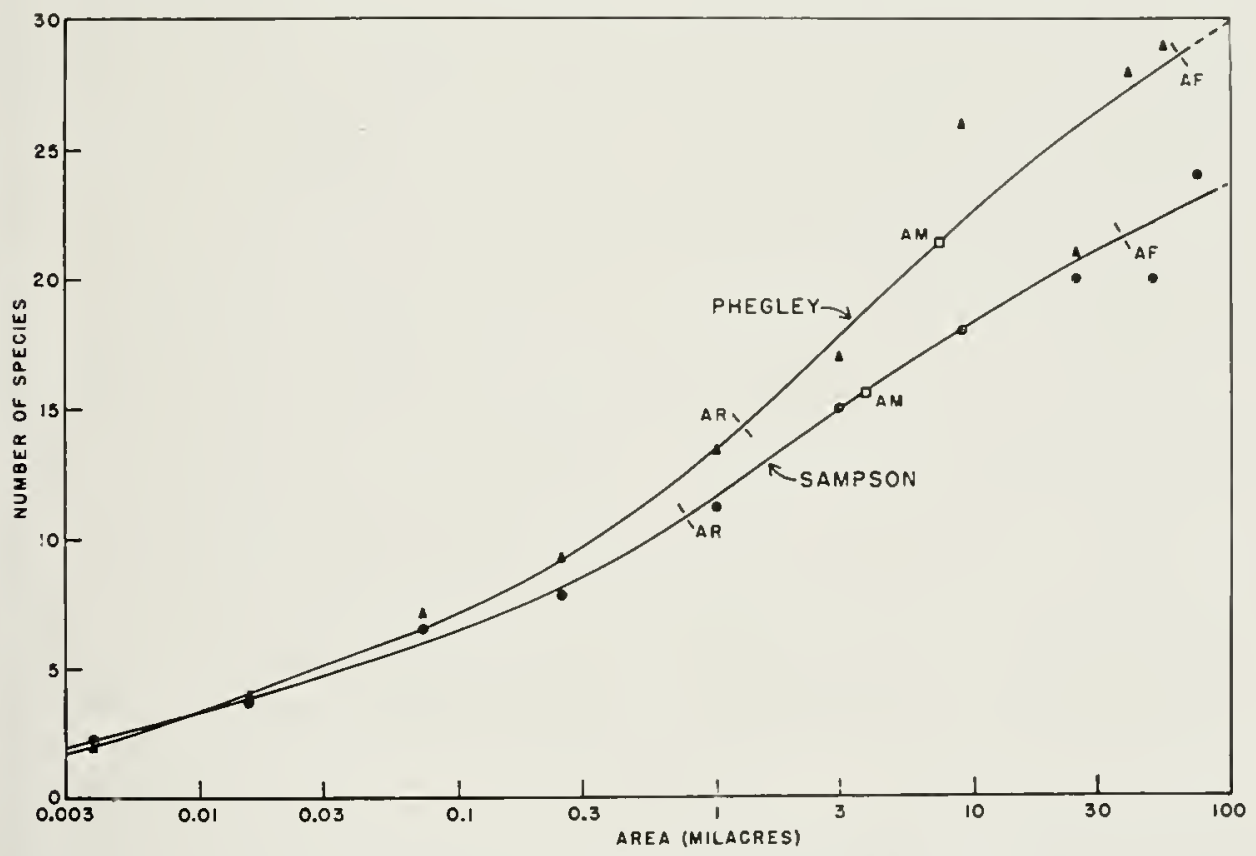

Fig. 13.-Species-area curves for Phegley (grazed) and Sampon (ungrazed) hill prairies. Ar, smallest representative area; Am, minimum area for assignment to type: Af, fair-sized stand. 
and a moderate number of minor species, is an area 5 times as large as the smallest representative area and wsually contains $1 .+t$ to 1.5 times as many species. It is the smallest size to he used if a single onepiece sample is to be examined. "The fairsimed stand ( $\mathrm{Af}$ ) is an area 50 times as large as the smallest representative areal and contains twice as man! species.

lour Sampon prairie, the curve indicates the smallest representative area to be 0.70 milacre, with 10.8 species; the computed minimum area 3.80 milacres, with 15.6 species, or $1.4+t$ times as many species as in the smallest representative area; the fair-sized stand 38.0 milacres, witlı 21.6 species.

For Phegley prairie, the curse indicates the smallest representative area to he 1.26 milacres, with 14.3 species; the computed minimum area 6.30 milacres, with 21.4 species, or 1.497 times the numher in the smallest representatice area; the fair-sized stand 63.0 milacres, with 28.6 species.

The 9-milace square was larger than the smallest representative area and minimum area for hoth prairies. Both prairies were of more than sufficient sime to gualify as fair-sized stands. The number of species in 1 acre was estimated to be 28.0 in Sampson and 35.2 in Phegley.

Summary of Pastured and Unpastured Prairies. - Some of the differences in regetation of the pastured and the unpastured hill prairies are here summarized.

1. The number of species in a quadrat was larger in the pastured than in the unpastured hill prairie.

2. Plant denaitl, hased on the number of plants in a quadrat, was smaller in the pastured than in the unpastured prairic; the grass bunches were smaller, less vigorous, and not so tall.

3. Grasses constituted a smaller percentage of the total number of individual plants in the pastured prairie than in the unpastured.

t. The ground space occupied hy grasses was smaller in the pastured prairie than in the unpastured.

5. Foliage area, or crown cover, was understandably much smaller in the pastured than in the unpastured prairie. $\mathrm{Al}$ so, the ratio of crown cover to ground space was smaller in the pastured prairie than in the unpastured prairie.

\section{Vegetation Charaeters From Other Stands}

In the preceding section, some analytic chatracters of vegetation were described for two hill prairic stands, Sampson and Phegley prairies. Analytic characters of vegetation, according to sone phytosociologists, are those traits which are studied in each stand. Sinthetic characters of vegetation are those which are studied from comparisons of large numbers of stands. Presence, a synthetic character of regetation, and seasonal aspect, alse synthetic in that it was described from observations made on most of the stands of 1 llinois hill prairies, are here brictly presented.

Presence.-Presence, as used here, is defined as the more or less persistent accurrence of a species in the stands of a plant community. Used for this study were 36 stands of hill prairies that the "Iriter visited at least twice during the field work. From species lists of the 36 stands, a table was devised which lists the species and the stands in which they occurred, table 1t. Species of forests or thickets and those of foreign origin were not included in the table unless they occurred in 18 or more of the stands.

Three species were present in 90 per cent or more of the stands. They were Indropogon scoparius, livgeron strigosus, and Bouteloue curtipendula. Six species were present in 80 to 89 per cent of the stands. They were Petalostemum purpureum, Euphorbia corollata, Penstemon pallidus, A. gerardi, l'erbena stricta, and Kuhnia eupatorioides. These nine species were the "constants" of the association: they can he classed as "constantly present." The "commonly present" species, that is, those present in 60 to 79 per cent of the stands, were Eupatorium altissimum, Rhus glabra. Oxalis ziolacea, Solidago nemoralis, Panicum scribnerianum. Aster ablongifolius, and Ruellin humilis. Species in 50 to 59 per cent of the stand were Linum sulcatum, Lithospermum incisum, Melilotus alba, Lespedeza capitata. Pyenanthemum pilosum, Pon praeensis. Psoralea tenuifora, Cassia fascicn- 
lata, and Sorghastrum nutans. Thus, in 50 per cent or more of the hill prairies. there were 25 species present. All are natives of North America except one, possibly two. Melilotus alba is Eurasian. Pon pratensis is generally considered European by many authorities, hut Gleason (1952) states. "In most of our range introduced from Europe: along our n. houndar" and in Canada it mat be native." lt might prove difficult to determine whether Illinois plants of this species had their origin in Europe or Canada.

Species most characteristic of the hill prairie type are Bouteloua curtipendula. Psoralea tenuiflora, Petalastemum candidum, Linum sulcatum, and Lithospermum incisum. The presence of these species in other prairie types in Illinois is much lower than in hill prairie.

Seasonal Aspect.-The Illinois hill prairies studied in the vears covered hy this report showed certain seasonal aspects.

In winter, the brownish color of the grass cover predominated. On some ungrazed hill prairies. tall grass stems of the previous growing season hent over and trended downslope to form a fairly complete cover over the soil. Small purplish rosettes of Solidago nemoralis and green rosettes of Senecio plattensis were evident between the grass clumps in some of the prairies.

The prevernal aspect was mostly brown. In early April in some prairies, the small white flowers of Draba reptans were seen. Br late April. the violet Howers of Oxalis rio'acea, the vellow-orange blossoms of Lithospermum canescens, and the vellowish flowers of Salix humilus and Rhus aromatica were evident among the grass bunches.

In the vernal phase, the dominant color changed from brown. through hrownishgreen. to green as the grasses hegan their growth. Hedcomn hispida. with very small b'uish blossoms, was common in the interspaces in many prairies. Erigeron strigosus, taller than the grasses during the vernal phase, was rery conspicuous with its-white flowers, as was also Penstemon pallidus. Tradescantia, with purple blooms raised above the level of the grasses. was scattered in many prairies.
The yellow rass of Senecio plattensis and Corevpis lavecolata were conspicuous in some. Several grasses. Panicum scrib nerianum. Poa pratensis, Festuca octoflora, and hoeleria istata, fowered at this time.

In the atestival stage, the predominating color was green or purplish-green. Eihimacea pallidn. with purplish rays, Was in hloom, and Linum suliatum, with small yellow petals, began its flowering. In some prairies the small whitish Howers of Honstonia nigricans were frequent. The inflorescences and toliage of Psoralca tenuifora gave some prairies a purplishgreen hue, especially in early Iuly. The purple-Howered Buclunera ampricana and Petalostemum purpureum and the whitefowered prairie-clover, $P$. candidum, were scattered in some prairies. In late June and early July, the green or purplishgreen inflorescences of Bouteloua curtipendula appeared. In the latter part of July and early August, the hronze, green, or purplish-green inflorescences of $t_{n-}$ dropogon scoparius and 1 gerardi were conspicuous. By late August, the rellow of Solidagn nemorn' is and the purple of Liatris aspera were evident.

In the autumnal phase, heginning in September, the doninant color changed from green to brownish hues. The rellow rays of Solidago nemoralis and the white or purple rars of several species of Aster were common. By Octoher. very tew plants, an occasional solidagn or a Howstonia, or, less often, a Spiranthes, were still in fower. By Noremher the prairie was again dormant; the dominant grass cover was hrown.

\section{VEGETATIONAL HISTORY AND SLCCESSION}

The regetational history of Illinois, a state that is within the area of overlap of eastern prairie and forest. is deduced mainly from circumstantial evidence. The evidence is derived from the present flora and regetation, especially from apparent relict colonics, from fossils in the loess, and from analyses of pollens and fossils in peat and lacustrine deposits. Deduction: must conform not only to the facts of hotany but also to the facts of meteorology 
and geology. In making deductions concerning plant succession and regetational history of 1 llinois hill prairies, it is necessary to keep in mind some of the Pleistocene history of the area in which these prairies occur.

The strip of land along the present Mississippi River valley in western Illinois has hat a regetational cover since Kansan glacial times, fig. 4 , except for the portion from southern Carroll County to northern Adams County, inclusive, which was covered by ice during part of llinoian glacial time. Except for a strip hetween Fulton. Whiteside Countw, and Cordora, Rock lsland County, which was coresed during Tazewell glacial time (Shaffer I95t), the entire western bordet has supported a plant cover since Sangamon interglacial time. It was during "arewell time that the present valley of the Misissippi from the Rack Island area s)uth to Adams (ounty was established. The eroding valley perhias did not maintain a continuous plant cover hut the adjacent uplands did; their cover was probably prairie.

The Illinos River valtey soush from the "Big Bend" at De Pue was establislied in pre-Pleistocene time and has been occupied by vegetation since Illinoian deglaciation except for the area from Peoria northward, which was glaciated again during lazewell time. The Rock River hill prairie sitc included in this report was not covered by ice after Farmdale glacial time. The area along the valley of Sangamon River near its mouth was last glaciated during l!linoian time.

It seems entirely possible that luring the Tazewell substage, when the ice-front was at the shelbyrille moraine, a fairly steep climatic gradient prevailed, with climatic conditions along the valleys in western Il]inow not very different from those of the present. Loess deposition occurred during the time of adrance, maximum extent, and recession of the glacial ice. The major deposition doubtless took place in the autumn and winter, which were then, as now, the dry seasons of the year. Loess deposits of Kansas contain fossil snails that point to a plant cover for that area at the time of deposition that consisted of shrubs and herbaceous spe- cies (Leonard 1952) and of a forest horder near the Missouri River (Leonard $\mathbf{S}$ Frye 195t). As the Kansas deposits are of comparable age to those of Illinois, a similar plant cover may have existed in parts of lllinois. The vegetation in much of western Illinois west of the Tazewell ice-front may be imagined as that of a prairie or grassland (Gleason 1923). The floodplains were devoid of plant cover hecause of the comstant shifting of the orerloaded streams with their braided channels. During the dry autummal and winter seasons, the floodplain served as at source of silt, which was transported to the uplands by the then, as now, prevailing northwest winds.

While separating bunch-grass clumps from Reavis Spring to expose individual plants (page 381), V'estal and the writer observed that vigorous upward growth of plants had kept pace with the deposition of additional sandy material. From such observations it can he concluded that, along the bluffs, deposition of loess farored rather than discouraged the growth of hunch grasses. The inverse also was true; a grass coser favored the catching and holding of windhlown silts (Shimek 1903). As new areas were exposed by deglaciation (for instance in the Putnam (ounty hill prairic locations), the prairie species, hecause of proximity and the rapidity with which many of them could hecome established, moved in and wecupied the bluffs before woody plants could do so. Mosses and lichens were not the first plants to become established in areas of deglaciation. On present-day loess and till slopes in Illinois, these cryptogamic species are absent from sizable areas without rascular plants but are present in some interstices where grass plants give some protection. A similar situation prohably prevailed during deglaciation. Prairie vegetation thus can be assumed to have long antedated tree cover on many of the bluffs of the larger rivers in Illinois. "The advantage of priority of occupation is probably far more important in succe. sion than is commonly realized.

Although subsequent history has per haps heen one of progressive encroachunent by forest on many of the lllinois bluffs. especially those of low altitude, several 
stretches of hluff frontage, totaling 25 to 30 miles, remain hill prairie or are in part hill prairie. Posibly as much as three times this extent, 75 to 90 miles, or about une-eighth of the bluff irontage on the east sides of the major stream vallers, was prairie in the early nineteenth century, but was converted to pasture or otherwise disturhed by the activities of man. The hases for such an estimation are the fer scattered prairie plants along stretches of blufts now occupied principally by bluegrass and numerous pasture weeds. Such stretches of hluffs are common along the Mississippi River in Jo Dariess County. Douhtless these bluffs were prairie cosered in the not distant past.

Hill prairies have been surprisingly successful in resisting destruction hy the grazing of domestic animals and hy some of the activities of man. There are no records to show how heasily these prairies were grazed by bison before the arrival of white men in Illinois. It is possible that bison grazed many hill prairies, but that they failed to reach some that were hidden by surrounding dense forest. Whether or not pastured hill prairies observed for this report are heing reduced hy overnasturing is not yet evident. Goat pasturing in one site along the bluffs of the Illinois River south of Rosedale caused complete destruction of the prairie, leaving only bare loess on the slope. The spread of residential and industrial areas has destroved some of the hill prairies. On the other hand, it is erident that fire has not destroyed them; seemingly, it has permitted an earlier and more tender growth of grass.

What is the probability that hill praires are now being invaded by forests? Some of the most tupical hill prairies are located on brow slopes where the cliffs are so high that they extend above the trees that grow on the toe slopes: without the shade of the trees, the brow slopes, especially those facing southwest, are exposed to the heat of the sun and to the prevailing winds of summer and are thus too veric for growith of mesophytic forest and will probahly remain prairie. The bluff coves, which serve as drainageways on the slopes, are more mesic and, in places, support mived forest. Such forested coves contain tree species that are found in the forests of the hasal sopres, the slopes of the trihutary valleys parallel to the main valleys, or of the uplands. Where the blutfs are low, or in the few places where the ascent from Hoodplain to upland is continuously of low gradient, trees have long shaded the upper slopes and greatly reduced wind morement. In such situation, forests have heen established over entire slupes.

In vears of abundant rainfall. forest seedlings hecome estahlished on prairie spurs, only to die in sears of less abumdant rainfall or in periods of successive dry years, as of the $1930 \%$. Dwarfed trees, as well as dead sumacs and red cedars, are reminders of dry years and a contest between forest and prairie. It thus seems probahle that a shifting equilibrium was long ago reached hetween prairie and forest, especially on bluff. with high cliffs. As long as the present topography and climate persist, such hill prairies will remain approximately ats they are.

Delimitation and description of the actual stages of succesion within hill prairie areas cannot be made now, but must await the advent of interested botanist. of the future. In the interim, it is important that butanists continue the study of these sites and publish the results of their studies. From such studies, hotanists will he able to trace actual, not hypothetical, paths of succession and also deduce with a greater amount of accuracs the past regetational history.

\section{ANNOTATED IIST OF HILI, PRAIRIES}

The following list of Illinois hill prairies includes only those prairies which the writer visited during the field work for this study: "lhe name given to each of the prairies was derived from one of sereral sources-the name of the landowner, or of the tenant, or of the firm on which the prairie was found; the name of that stretch of blutf occupied by the prairic; or the name of some nearby landmark or community as applied locally or found on a yuadrangle of the Lnited State's Geological Surver topographic map. L.ncation of each pratire is given alcoording to 
section, town, and range except for pratries within municipalities, state parks, or the old French land grants. The'se grants extencled inland at right angles to the bank of the Mississinpi River ambl were not surveyed according to the township sytem. In this hill pratrie study, such grants were encountered in Monroe and Randolph counties.

For convenience in listing, the praires are divided inio three eroups. (a) those along the Mississippi River from Last Dubueque to Graftom, (b) those along the Rock. Sangamon, and lllinois rivers, and (c) those along the Mississippi River from Gratfon to ('airo and elsewhere in southern Illinos. (O) the bluffs south of Warsaw. Hancock County, were sereral small openings which were seen but not examined for this study. Nlso, on the wouth side of the lower Sangamon River valley were a number of hilt prairies. some with north- and northwest-ficing sopes. Many of these prairie slopes served as pastureland and were much disturbed. Some of the slopes were completely converted to b!uegrass pasturedand. None of these slopes was risited. Fig. I shows the locations of these hill prairice sites. Not dexcribed, nor indicated in fig. 1 , are sereral pastured grass slopes on the bluff. of the Mississippi River, went and south of Galena, Io Daviess County, which were visited June 15-16, 1950. At that time they were covered with many weeds and they contained few prairie plants.

\section{East Dubuque to Grafton}

El Rancho.-This prairie, locited on the bluff above the El Rancho Cafe in Fast 1)ubuque, Jo Dariess Count, Was visited July 16 and October 4. 1950; May 9 and June 1t. 1951. Prairic, slighily over an acre in area. covered the stony part of the slope above the cliff. and also the loess on that part of the slope above the stony part. The uppermost part of the slope and the zenerally flat blufftop, greatly disturbed by the IVPA in constructing stone foundations for a fireplace and two shelters, had been much trampled and was weedy. Two Indian mounds crowned the spur nearest the cafe. A forested cove separated this spur from another to the south. Three Indian mounds occupied the crest of the southern spur. Andropogon scoparius was the dominant grass of both spurs; Stipa spartea grew in large patehes on the south spur and was in smaller, sattered patches on the north spur.

Menomince Station.- This prairie, in the suthwest fuarter of section 17, $T$. $27 \mathrm{~N} . \mathrm{R} .1 \mathrm{~W}$., on the bluffs of the Mississippi River, about one-half mile southrast of Menominee Station, Jo Davies. Counts, was visited Octuber t, 1950; Mal 9 and June 14, 1951. Prairie cosered about $t$ acres on parts of four southwest-facing spurs. Rock fromgents covered the surface tor a few yad above the rock leilge; loess capped the bluff. Indropogon scoparius was the dominant grass. The northeast-facing slope of the northernmost spur and the uplands adjoining the remaining spurs supported a mixed forest. Rhus glabira formed dense stinds on three spur-tops, and it extended downstope on the north sides of these spurs. Populus tremuloides occupied a part of the crest of the northermmost spur of this prairie.

North Savanna.-Prairic covered the upper southwest- and west-facing slopes of the bluff-ridge in section 21 , 'T'. $25 \mathrm{~N}$. R. 3 E., 3 miles north of Savanni, Carroll County, when the site was visited June 14, 1951. On the slopes above the rock ledge, Bonteloun hirsutn was abundant. Disturbed prairie covered the crest of the ridge. Northward along the ridge, the slope and top were occupied almost entirely by Juniperus airginiana.

Sunset Trail.-At the time this study was made, prairie occupied one northwestfacing spur, three west-facing spurs, and one south- to southwest-facing spur on the bluff north of the Administration Building in the Mississippi Palisades State Park, north of Savanna, Carroll County. A trail, Sunset Trail, crossed parts of this prairie. Andropogon scosparius and Boufeloun curtipemlula were abundant grasses. Sandy loess covered the northwest-and west-facing slopes; the south-facing slope was stony. "The stom! lope was not so steen als the loes slopes. Thene spurs were risited October $t, 1950$, and June 1t, 1951. 
Hill-Top.-This prairie opening, when examined October 5, 1950. occupied about +.5 acres on the uppernost surface of the bluff, one ravine south from the main entrance to the Mississippi Palisades State Park. A mixed forest surrounded the prairie. Sorghastrum nutans was the dominant grass: Panicum qirqutum was abundant. Several paths crossed the prairie. Here and for a short distance into the prairie, weeds were common.

South Palisades.-This prairie occupied about 0.2 acre of the generally stony southwest-facing ridge-slope north of the abandoned quarry near the southern boundary of the Mississippi Palicades State Park, when observations were made there on June 22 and Octoher 5, 1951. Andropogon scoparius was the dominant grass.

Bielema.-Prairie occupied slightly more than an acre of the blutf on the Bielema farm in section 32, T. 23 N., R. t E., southeast of 'Thomson, Carroll County, in 1950. Stones strewed the lower slope; sandy loess comprised the upper. The base of the lower slope, much disturbed by pigs, was weedy. Pralirie, with Bouteloua curtipendula and Andropogon scoparius as dominant grasses, covered the upper part of the rocky slope. Andropogon scoparius was the dominant grass on the sandy loess, except where shallow drainageways on both the stony and loess slopes were densely covered by drtemisia caudata. Poa pratensis was the dominant cover on the northern part of the bluff-top; Bouteloun curtipendula dominated the southern part of this surface. Bielema prairie was visited June 23 and October 6, 1950.

Balk.-In 1951, two conspicuous prairie openings, together about 1 acre, were observed on the upper west-facing slope of the bluff-ridge in section $5, \%, 22 \mathrm{~N}$., R. + E., in Whiteside County. 'The southern opening and the surrounding forest were frequented by pigs; the northern opening, which was separated from the southern by a fence, was unpastured. Bouteloua hirsuta and Stipa spartea occurred in these-openings. This site was visited June 13, 1951.

Wiersma.-Hill prairie, about 0.5 acre in area, occupied the upper west-facing slope of the bluff-ridge on the Wiersmat farm in section 8, T. 22 N., R. + E., Whiteside County, in 1950. Bouteloua curtipendula was apparently the dominant grass; Andropogon scoparius was locally abundant. The entire ridge was hearily pastured. Wiersma prairie wats visited October 6, 1950.

Rock Island 31. - This site, located in section 31, T. 16 N., R. 5 W., Rock Istand County, was visited September 9, 1949. The slope, heavily pastured, and covered with a mixture of prairie and forest, was stony helow and capped with sandy loess. Audropogon scoparius, $A$. gerardi. Sorghastrum nutans, and Bouteloua hirsuta were some of the grasses on this slope.

Bald Bluff.- 1 he name denotes the prominent, narrow, northwest-projecting arm of the Mississippi bluffs in section 18, "1. 12 N., R. + W. Henderson Cuunty. Mantled with sandy loess, Bald Bluff supported both mixed forest and prairie when visited. 'This prairie, with an abundance of Bouteloua hirsuta and many weedy species, was heavily pastured. Prairie curered about 9 acres, 3 of which were exanined on August 18, 1951.

Ursa.-When visited, this hill prairie occupied the southwest- and west-facing slopes on the north side of Ursa Creek valley where the creek enters the Mississipni River bottomland in section 13, T. 1 N., R. 9 W., Adam County. Prairie covered about $i$ acre of the slopes. A stony levee and small spring-fed stream separated the road on the west from the bluff to the east. The stony east hank of the stream supported prairic. Small rock outcrops capped the stream hank. Above these outcrops the surface was almost level. A dense stand of Juniperus rirginiann with scattered individuals of Quercus muhlenbergii and Cornus drummondi grew on the level surface near the limestone outcrops. Listward there was a narrow belt of prairie and bevond that a thicket which included small raks, basswood, and hop hornbeam. This thicket bordered the hase of a steep loess spur which was covered by prairic up to the top of the bluff. Prairie covered the southwest-facing spurs, mixed forest the coves. 'lhe bluff-top was at mixture of 
prairie and sumac. Ursa prairie was visited August 11 and September 9, 1050: June 2 and July 1t, 1951.

Rock Creek.-Located north of Rock Creek, in the northwest quarter of section 25, 'T. 1 N., R. 9 W., Adams Coun$t y$, this prairie when visited covered more than an acre of a ridge of sandy loess. Andropogon scoparius wats the dominant grass; $A$. gerardi and Bouteloun curtipendula were present. Asclepias stemophylla and Chenopodium leppophyllum oceurred in the interspaces. Psoralea tenuiftora was common on the gentle lower slope and the almost level top. but was infrequent on the stecper slopes. Roxk Creek prairie was visited September 8, 1949 ; August 11, 1950; April 25, June 2, and July $1+, 1951$.

Homan. - This name, which is also the name of the creek to the east, here designates the small hill prairie that in 1951 occupied stighty more than an acre in section 11, T. 1 S.. R. 9 W., about 3 miles north of Quincy. Prairie covered the west-and southwest-facing slopes of the southern tip of a ridge that ends at Homan Creck. The crest of the ridge was almost covered with Rhus glabra, Psoralea tenuifora, Petalostemum candidum, and Melilofus alba. A few individuals of Asclepias stenophylla and Delphiminm carolinianum occurred there ats well as on the slopes. V'egetation of the east-facing slope was principally a mixture of prairie and sumac. Andropogon scoparius dominated the west- and southwest-facing slopes. Bouteloun curtipendula accurred in scattered patches. This site was visited on April 25. June 2, and July 16, 1951.

Parker Heights.-This small hill prairie, which occupied the south part of a ridge in Parker Heights, a park about a mile north of Quincy, Adams County, was visited May 28, 1950, and July 16 , 1951. Disturbed prairie, much trampled by people, covered the west- and southwest-facing slopes above the exposed limestone bedrock.

Hidden Lake.-The pond within the quarry in the southeast quarter of section 23, T. 2 S., R. 9 W., ahout 2 miles south of Quincy, provided the name for this site. A wall of limestone which forms the north and east limits of the lake is covered with a thick mantle of loess to form the bluft. Above the bedrock, the mantle of loess forms an almost vertical cliff witl heights to 15 feet, and above the loess cliff is the gentle west- and southwest-facing brow slope of the bluff. Hidden Lake prairie, when visited Septemher S, 19+9, and May 28, July 2, August 13, and September 9, 1950, covered about 0.2 acre of this slope. 'The steep loess face was almost without vegetation except at its junction with bedrock. Small slıruhs occupied this junction. "1"he prairic had heen much disturbed by human trampling, hecause the site attracted numerous hoys from nearly Quincy. Amdropagon scoparius was dominant on the slopes. A dense stand of Rhus glabra, Melilotus alla, and 1 . scoparius occupied the crest of the ridge. Tridens flaz'us was frequent.

Sechorm Cemetery.-This prairie, located on the uppermust slope of the bluff, in the southeast quarter of section 26, 'T'. 3 S., R. 8 W., Adams County, was risited September 9, 1950. Prairic occupied the cemetery and some of the slope to the northwest and southeast. Downslope there was a mixed forest; upslope a hit of prairic was found hetween the cemetery and the cultivated upland. Sorghastrum mutans was the dominant grass. Andropogonn gerardi, Bouteloua curtipendula, and Psoralen temiflora were common.

Fall Creek. - This prairie in 1950 occupied the bluff about one-quarter mile south of Seehorn Cemetery prairie. Mixed forest occupied the coves; forest, or a mixture of prairie and forest, covered the spurs. Andropogon scoparius, $d$. gerardi, and Sorghastrum mutans appeared equally abundant. Interspaces between the bunches of grass were small. This area was visited September 9, 1950.

North Pandarmie. - This name designates a group of spurs and coves on the bluffs in section 31 , T. 3 S., R. $7 \mathrm{WV}$., and section 36, "J. 3 S., R. 8 W., north of Pandarmie Hollow, 2.5 miles southeast of Fall Creek, Adams County. When North Pandarmie was visited September 9, 1950, forest occupied the coves: a mixture of prairie and forest covered the spurs. Andropogon gerndi and Sor- 


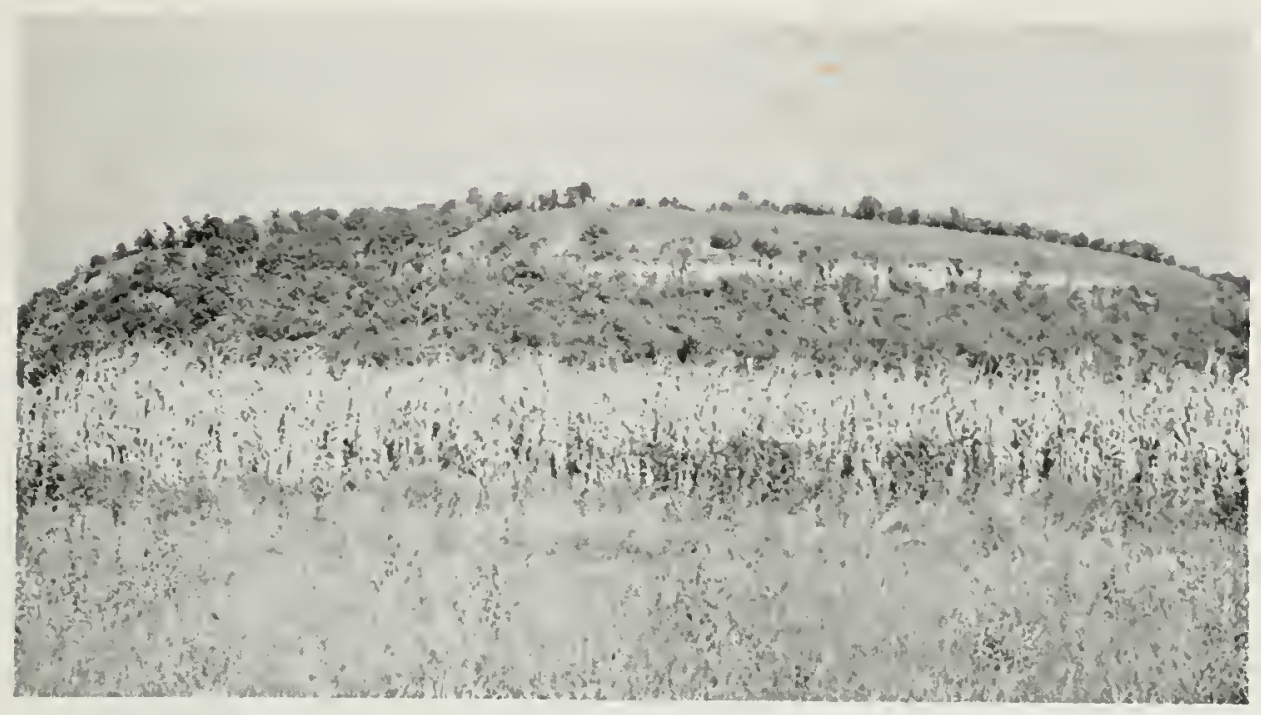

Fig. 14.- Housen hill prairie, north of Rockport, Pike County. The forest of the basal slope extends to the bluff top through the drainageway at the left of the prairie.

ghastrum nutans were abundant; A. scoparius was infrequent. At the top of the brow slope was a strip of woodland. Its northeast side had a dense border, 3 to 6 feet wide, of Sorghastrum. At the base of the spurs, Mentzelia oligosperma grew in the crevices of the interrupted rock ledge.

Seehorn-Payson.-The name of this hill prairie comes from a village in Pike County and a township in Adans County. In 1950, prairie occupied about an acre of slope: part of this area was in the southwest quarter of section $31, T, 3 \mathrm{~S}$. R. 7 W., Adans County, and part in section 6, T. + S., R. 7 W., in Pike Cinnty. Astragalus distortus occurred on the loess and on the rock ledges. Mentzelia oligosperma grew on the rock ledges and the rocky slope above the ledges. The prairie was heavily pastured by cattle and sheep. Poa pratensis was the most abundant grass on the prairie slopes; Andropogon scoparius was infrequent. In September, 1950 , sery little of the herbaceous vegetation was more than 6 inches tall; the average was 3 to $t$ inches, except for an occasional bunch of Bouteloun curtipendula. This prairie was visited Ma! 28, July 2 , and September 9, 1950.

Sessions. - In the 3 years this hill prairie was under observation, it occupied about 4.5 acres of the upper southwestand south-facing slope of the bluff in section 5, T. 5 S., R. 6 W., on the Sessions farm between Kinderhook and New (anton in Pike County. Prairie covered seven spurs, mixed forest the intervening coves. Above the rock ledge was a stony slope covered with prairie. Loess mantled the bluff. There was a generally Hat upland to the northeast of the slope. Prairie covered the almost flat spur-tops and some of the Aat upland to the northeast. Much Rhus glabra grew on this Hat surface and at the heads of the south-facing coves. Andropogon scoparius was the dominant grass. The entire site served as a pasture. I isits were made to Sessions hill prairie on September 7, 1949; May 28, July 2, September 8, 1950; and April 24,1951.

South New Canton.-A small hill prairie, less than 1,000 square feet in area, in 1950 occupied the sourhwest-facing bluff slope soutlieast of Morey Cenetery, about a mile southward along the huff. from New Canton, Pike County. A rocky slope lay above the rock ledge, and locss capped the bluff. Andropogon scoparius was the dominant grass. Mentzelio oligosperma grew ahundantly in the crevices and recesses of the ledge and infrequently on the lower part of the loess slope. "Tlie" entire bluff and the upland ridge to the 
northeant was pastured and much disturbed. Iisits were male to this site on May 27. July I. and Sepiember S. 1950.

Iousen.- IVhen risited April 2t, 1951, this hill pratric in the southeats (puarter of section 7, 1\%.6 S., R. 5 11., on the Housen farm north of Reckport. Pike County, covered more than an acre of the uppermost southwest-ficing slope of the crest of the ridge grew a mixture of prairie, woulland, cultivated plints, and weeds. Some of the plants growing in this site were Lespedezo stipulacen. Symphorial pos orbiculaus, Melilotus alba, Tridens flaz'us, Bontoloun curtipendula, itn. dropogon scoparius, d. gerardi, I'erbena tricta, and Eragrostis cilianensis. "The" inner. or northeast, slope of the ridge sup-

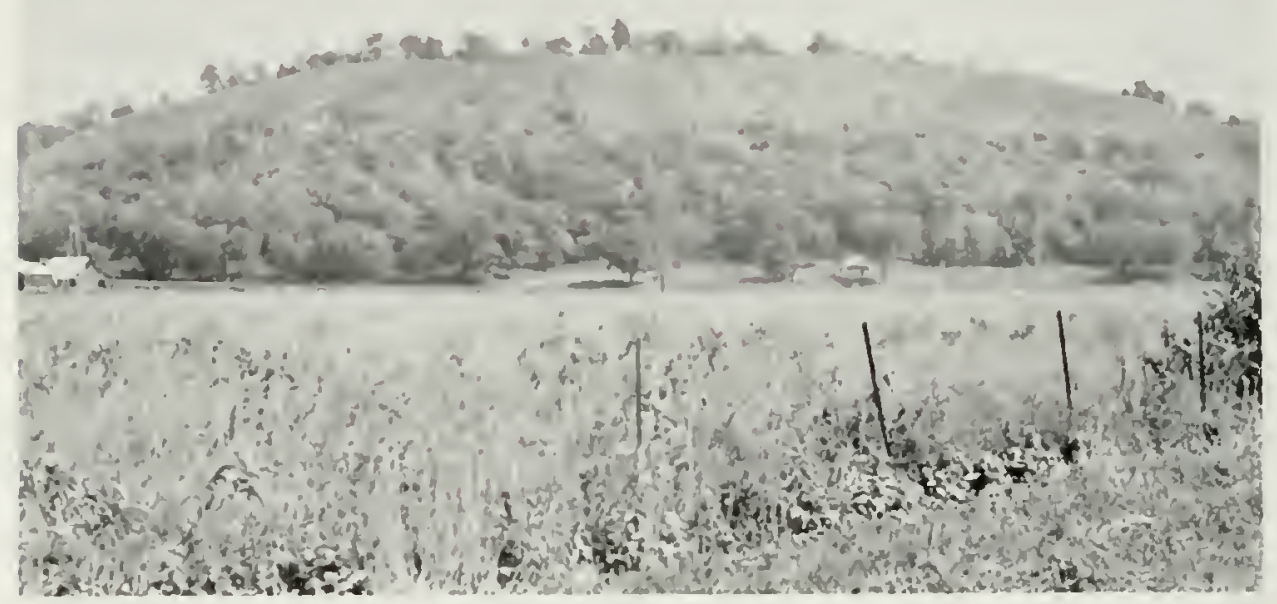

Fig. 15.-The Clendenny hill prairie, northwest of Belleview, Calhoun County. Buchnera americana was common in parts of this prairie.

ridere shown in hig. 1t. Indropogon scoparius was the dominant erass; d. gerardi and Bouteloua curtipendula were present. The prairie and a part of the adjacent woodland on the slope to the northeast were burned during the antumn of 1950 by a fire that swept the bluffi from Rockport northward to a point heyond this prairice.

Clendenny:- When last seen, this hill prairic, located in the northwest quarter of section 12, \%. \& S., R. + 11. about 2.3 miles north of Belleriew. Calhoun C'ounty. covered about 7 acres of the uplermost southwest-facing slope of a bluff. This blufi, fig. 15, served as the pasture of the Clendenny farm. Prairic covered the rocky slope above the rock ledge except in a few coves where a mixed forest extended upslope. Loess capped the bluff. Prairie covered the spurs and most of the coves; small trees and shrubs grew in scattered clumps in some coves. On the ported both forest and prairie: mixed forest on the northwest part and a mixture of prairie and forest on the southeast part. Clendenny prairie was visited April 15. Maly 27, and September 8. 1950; August 30 and September 27, 1951.

Sirarnes, - An inscription on the monument at the crest of the bluff in the northeast quarter of section 35. T. 9 S. R. $3 \mathrm{WV}$, at the north limits of Hamburg. Callown County, furnished the name for this hill prairie. When the site was last scen, prairic occupied about 2 acres of the west- and southwest-facing slope of the ridge. A fence located a few feet north

\footnotetext{
- The following inscription appears un this monument In Memory of

l.ewis Swarnes, according to several recidents of Ilant. buec was a riverboar cantain. He became ill on orie of his urins and requested thas his body should be buried on the bluff overlooking the Mlississippi River at Ham-
} burg. 


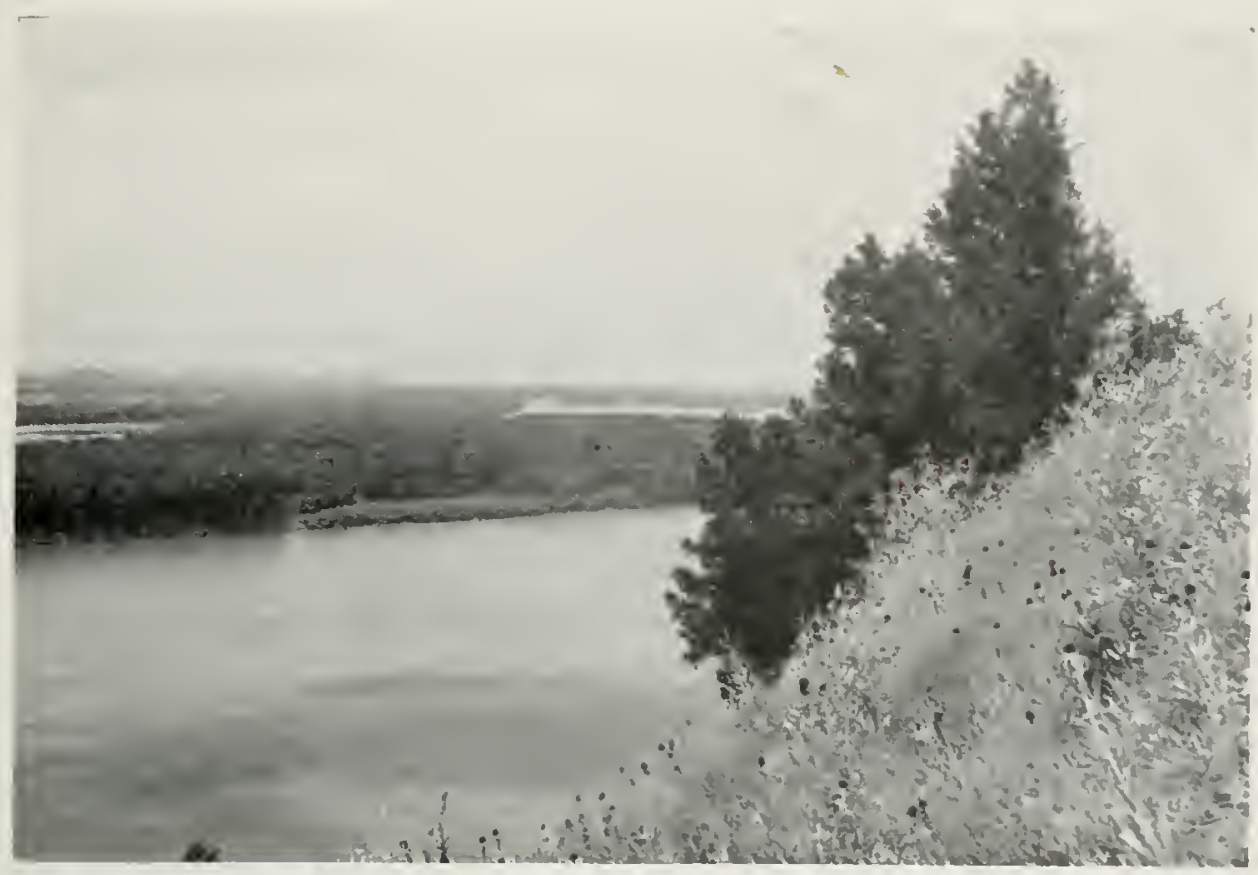

Fig. 16.-Part of the west-facing slope of Swarnes hill prairie at Hamburg. Calhoun County. Echinacea, . Mclilotus, and Psoralea were common on this slope.

of the monument divided the prairie al most equally into pastured and unpastured areas. The pastured segment occupied a west-facing slope, fig. 16. the unpastured a west- and sourhwest-facing slope. The unpastured surface that bordered the rock ledge was stony, level near the ledge, and gradually steepening upward from the ledge. Bouteloun curtipendula was there locally dominant. Interspaces contained many individuals of Houstonia nigricans. The unpastured prairie of the steeper slopes and the top of the loess-capped bluff were dominated by Andropogon scoparius. Scattered clumps of Bouteloua curtipendula and $t$. gerardi were present, and Asclepias stenophylla occurred occasionally in the interspaces. The pastured slope supported a prairie that was dominated by $f$. scoparius. Near the top of the bluff, as well as at the top, Rhus glabra was locally dominant. Psoralea tenuifora was common in the pastured prairie area. Swarnes prairie was visited September 7. 1949; April 1f, May 2i, July 1, and Augusi 12. 1950; and September 27, 1951.

\section{Along Rock, Sangamon, and Illinois Rivers}

Devil's Backbone.-The bluff-ridge that extends along the Rock River in the northeast quarter of section $16, T .23 \mathrm{~N}$., R. 10 E., south of Oregon, Ogle County, is given the name Devil's Backhone on the Dixon quadrangle of the Inited States Geological Survey topographic map. St. Peter sandsione underlies this rilge. When the ridge was last seen, one southeast- and two northeast-facing prairie openings occupied the upper stony and sandy slope.s. Sandstone fragments were abundant on the northeast-facing slope. The openings on this slope were covered with prairie in which $P o a$ pratensis was very abundant, Andropogon scoparius less ahundant, and Bouteloua curtipendula scattered throughout. Synthyris bullii also grew there. The southeast-facing opening was a sand prairie on a slope. A. scoparius was there the dominant grass. Selaginella rupestris, together with mosses and Andrasace occidentalis, grew in the interspaces. Deril's Backbone was visited 
on lune 23 and October 3, 1950, and May 7, 1951.

Standard.-In 1951, prairie occupied about a half acre of the upper southwestfacing ravine slope in section 26, $1 \% .33$ N., R. I W., I mile west and 3 miles north of Standard Putnam County. P'etalostemum purpureum, Imorplia canescens, and Corcopsis pa!mata were some of the plants in this prairie. This site was visited July 7, 1951.

Magnolia.-When the prairie opening given this name was last visted, it ocenpied slightly less than an acre on the west- to south-facing upper slope of the bluff in the southwest quarter of section 3t, $\mathrm{I} .31 \mathrm{~N}$., R. $2 \mathrm{~W}$., about 7 miles west of Magmolia, Putnam County. The bluff is capped with till: loess, if present, apparently is very thin. Scattered shrubs of Rhus glabra occurred throughout the opening. Cormus drummondi and small elms grew on the south-facing slope. where also a tew deat and scattered stems of hones locust were seen. Indropogon scoparius was the dominant grass. Comandra umbellata was very ahundant, Psaralen tenuiflora common. Mixed forest surrounded this prairie opening. Magnolia prairie was visited on September 29. 1947: May 16 and dugust t. 1950.

East Henry:-This name designates a group of five prairie openings on the southwest-facing bluff of Sandy Creek: the bluff is in the northwest quarter of section 3, "T. 30 N., R. 2 W., and southeast of Henry, Marshall County. When the area was visited August $t, 1950$, the westernmost opening was wedy and much disturbed. At the base of the b'utf below this opening was a gravel pit. The next opening easward supported prairie plants and also a thicket of Rhus glabra. Cornus drummondi, Malus ioensis, and L Tmus sp. "This opening and the next one to the east were pastured. In the prairie areas, Andropogon scoparius was the dominant grass, Bouteloun curtipendula, Psoralea temuifora, and Silphium laciniatum were common. Weeds, Chamaesyce maculara, Medicagn lupüinn, Poinsettia deniata, and Melilotus alba, were frequently encountered in these areas. Prairie openings on the two eastermmost spur were not examined.
Reavis Spring.-1his prairie, when visited, covered almost 19 acres of the sandy loess bluffs in parts of sections 25 . 26 , and $36, \%$. 20 N., R. $7 \mathrm{~W}$., about 5 miles south of Easton, Mason County. The name Rravis Spring was that of a school house, abandoned and later remosed, that once occupied a part of the lower slope of the bluff in section 26. A road, which followed the general southwest-facing bluff, was on the lower sandy slopes. Downs!ope to the southwest was a series of thickets and cultivated fields. Upslope to the northeast was the prairie, which oicupied numerous spurs. "Thicket covered the hases of some coves, shrubs or prairice the upper slopes. Prairie covered the erests of the spurs; mixed forest or prairic occupied the tops of the hlufts.

The blufis at Reavis Spring prairie rise 256 feet above the Sangamon River hottomland and are higher than the dissected upland to the northeast. 'The valley orerlooked by these bluffs is notable in several respects. It has a wide bottom trending generally east-west. The Sangamon River enters it from the south and joins a small, west-flowing stream, Salt Creek, in section 6, \%. 19 N., R. 6 W., about 1 mile upstream from the Reavis Spring location. The valley is about as wide, rather surprisingly; above the junction of the Sangamon River with the small stream as below it. Salt Creek has a rolume too small to account for so wide a valley. It is probable that through this valley a glacial torrent once drained a part of the Wisconsin ice-front, then some miles east of the Reavis Spring site, and brought down huge amounts of sand and silt. From these were derived the thick deposits of loess and fine sand on the bordering bluffs. (Other sizable hill prairies necur or did occur on the bluffs for a few miles east of the junction of Salt Creek with the Sangamon River.

Reavis Spring prairie was visited September 15. 1949; July 6, 1950; May 18, 1951; and March 25, 1952. The dominant grass was dudropogon scoparius. Also growing in the prairie were tgoseris cuspidata, Polytaenia nuthallii, and the easily overlooked Spiranthes cernua. 'The prairie, which served as a cow pasture, contained a number of weeds, J'rrbascum 
thapsus, Achillea millefolium, and Setaria viridis. On the last visit it was found that the prairie had been burned a week before, fig. 17. From the tenant farmer it was learned that this prairie is hurned in early spring each year to allow an ear-
Mud Creck.- In the rears of this study, prairic occupied much of tha sandy luess ridge that separates the bottomland of the lllinois River from Mud Creek in the northeast quarter of section 1, 'I. 16 I., R. 1111 ., Morgan County. A thicket

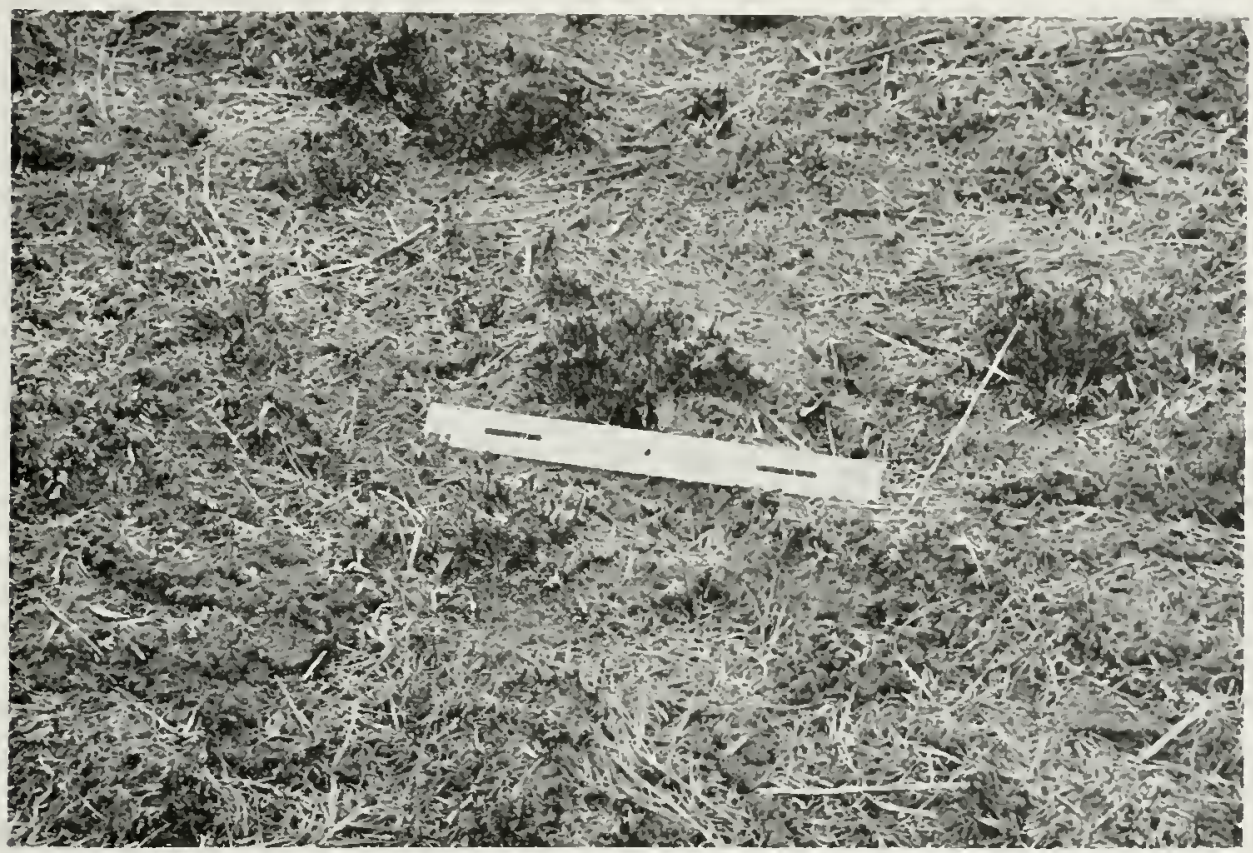

Fig. 17. - Surface of Reavis Spring hill prairie after an early spring fire. The size of rhe clumps of Andropogon scoparius is evident by comparison with the 1 -foot rule.

lier and more tender growth of grass than would normally occur.

Bluff Springs.-Disturbed prairie, which covered about a half acre on the north part of a loess mound in the southwest quarter of section 21, T. $18 \mathrm{~N}$., R. $11 \mathrm{~W}, 0.1$ mile north of Bluff Springs, Cass County, was risited September 15, 1949; July 6, 1950; and Mar 18, 1951. The mound and the adjacent lower slopes were pastured. The lower slope on the west was occupied by a mesophytic disturbed prairie with Pon pratensis locally dominant. The steeper slopes of the mound were prairie, with Andropogon scoparius the dominant grass. Bouteloun curtipendula and several plants of Spiranthes cernua occurred on these slopes. The almost level top, which had been much disturbed by trampling, supported a mixture of prairie and weeds. bordered the road on the lower nortlwest-facing slope. This thicket extended into the coves and partly up the cove slopes. Prairie covered the spurs and ridge-top, fig. 18. The dominant gras: was dudropogon scoparius. Bouteloua curtipendula and $B$. hirsuta grew in scattered clumps in the prairie, Psoralea senuiflora was common, and Sistrinclinum campestre rery abundant. All of this prairie and that part of the ridge that was covered with thicket, ahout 13 acres in area, served as a cow pasture. lisits were made to Mlud Creek prairie on July 6. 1950; Mal 1S, 1951; and March 25, 1952.

Northeast Meredosia.-When last seen. this prairic covered about 7 acres of the loess bluffs in section 9, T. $16 \mathrm{N.,} \mathrm{R.}$ $12 \mathrm{~W}$.. about 6 mi!es northeast of $\mathrm{Meg}\left(\mathrm{C}^{-}\right.$ dosia, Morgan County. Andropogon sco- 
parius wats the dominant griss. Bontelond curtipendula, as well as b. hirsusta, was scattered throughout. Jolygala imearmata grew on the hluff top, and Ire'misin candata grew as scattered individuals in the samely loess. lhiv prairie, Which served as pastureland, was visited septemher 15.
Psoralea tenuiflora, Onosmodium ocridentale, and Ambrosin curronopifolia.

Walnut Creek.- The site of this 2 . icte prairie occupies one southwest- and two west-facing spurs of the bluff north of which $1 \mathrm{~V}_{\text {alnut }}$ Creek enters the Mllinois liver villes in the northwest quar-

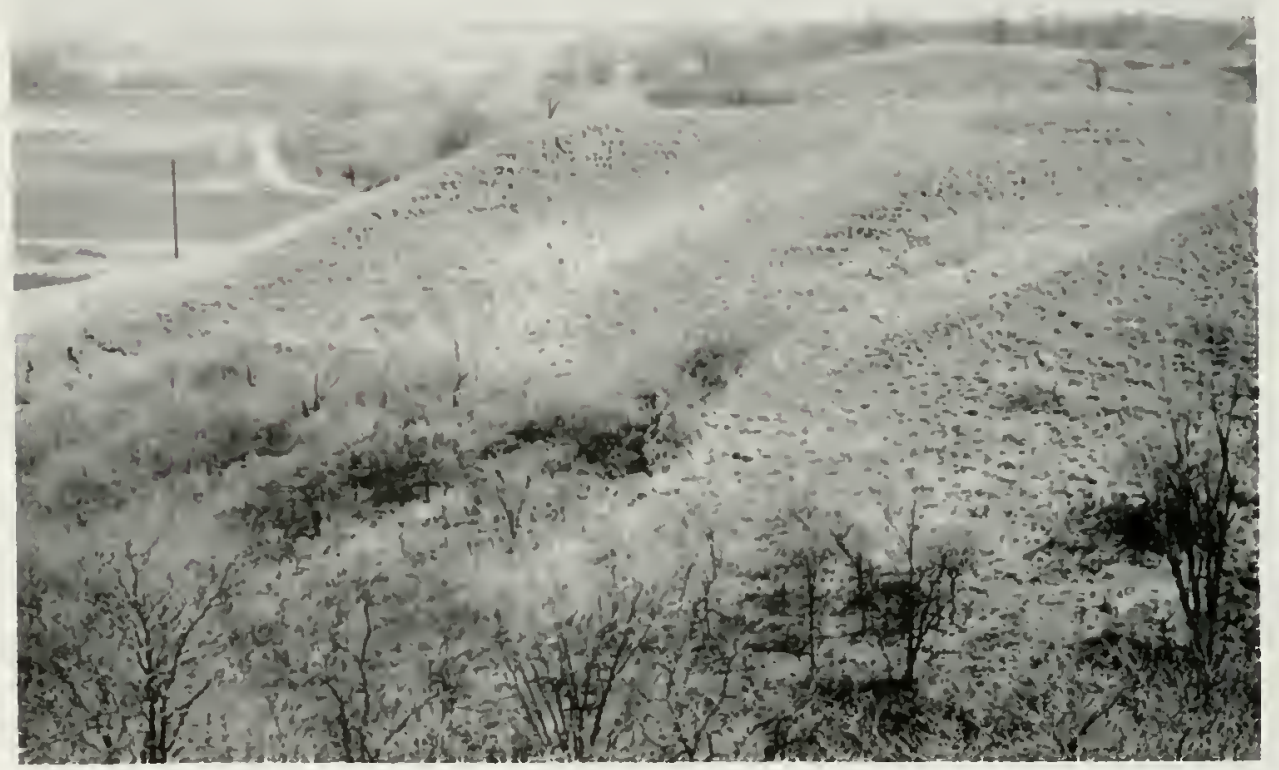

Fig. 18. - Spurs of Mul (reck hill prairie (center of picture) in northwes Mlorgan County. In the distance hevont the Mud creeh prairice are soptes, some of which support prairic.

1949; July 6. 1950) . II:1 19 1951; and March 25, 1952.

Northesist Meredosial was the lirst of those hill prairies along the lllinoin River observed by A. C. Vestal, who visited it in the spring of 1931 in compans with James M. Schopf and Herman I3. Wascher. They were impressed by the persistence of native prairie vegctation and by the lack of serious erosion on the steep loess slopes, over which the cuntinuous trampling of cattle had worn steplike cowpatls.

Bluffs. When this site Was visited July 6,1950 , a mixture of prairie and forest covered ahout 8 acres of the westfacing slope of the bluff in the southwest quarter of section 10. T. 15 N.. R. 13 II., north of Bluffs, Scott County. Prairie species included Lespedezu capitnta, ter of section 26, 'T. It N., R. $13 \mathrm{~W}$. ahout + miles west of $\mathbf{W}$ inchester, Scott County. When visited August 13, 1950. and April 24 and 11ay 18. 1951, the base of the slope contained a mixture of prairie and shrubber!. The spur slopes coritained prairie, with Andropogon scoparius the dominant grass. The coves between the spurs supported prairie and some woods plants. The top of the ridge was very weedy. Walnut Creek prairie was used as a horse pasture.

North Eldred.-Lncated in section 16, T. 10 N., R. 13 W., 2 miles north of Eldred, Greene County, this prairie in 1949 and 1950 covered several spurs on the upper slope of the bluff. The spur directly above the cemetery at the have of the bluff was heavily pastured; the spurs to the south of this were also pastured but 
not so greatly disturbed. Stones strewed the slope in places just above the rock ledge; sandy loess and sand capped the bluff. This prairic was visited September 1, 1949; April 14, May 23, and July $25,1950$.

South Eldred.-ln 1950, prairie covered about +.5 acres of two southwestfacing slopes in the southwest quarter of section t, $\mathrm{T} .9 \mathrm{~N} ., \mathrm{R}, 13 \mathrm{~N}, 2$ miles south of Eldred, Greene County. The prairie formed an inverted $U$ with the prongs of the $U$ extending downslope. Andropogon scoparius was the dominant grass; Senecio plattensis and Lithospermum canescens were common. This site was visited May 23, 1950.

Richwood.-When last risited, this prairie, in the southeast quarter of section 8, T. 8 N., R. $13 \mathrm{~W}$., Richwood Township, Jersey County, occupied $t$ acres of the long, curved ridge which extends from the rock ledge on the southrest up to the bluff-top. The abundant grasses were Andropogon scoparius, A. gerardi, and Bouteloua curtipendula. A small arm of the prairie stretched northwestward on a small branch of the ridge. A mixed forest covered the bluff slope to the west and the ravines on the east and north. Richwood was visited September 7, 19+9, and May 23, 1950.

Pere Marquette. - At the time of this study, prairie vegetation iccupied about 3.5 acres on the spurs of the southwestfacing bluffs, Pere Marquette State Park, west of Grafton, Jersey County. The prairie observed for this study was on the slopes west of the westermost parking area that was located on the crest of the bluff. Mixed forest grew in the coves between the grass-covered spurs. A little helow the top of the eastern and central spurs a firehreak crossed the prairie. Veeds, including Ambrosia clatior and Erigeron canadensis, grew among scattered plants of prairie species in this firehreak. The dominant grass of the prairie slope was Andropogon scoparius. Desmantlus illinoensis grew on the western spur and was very abundant on the central one. The western spur was disturbed by a bridle path which followed the crest of the spur and had cut 2 feet into the loess. The bluff-top was covered by a thicket of suall trees and shruhs, including Cratoegus crus-galli, Cormus drummondi, llalus iocnsis, Cereis canudensis, and Sassafras albidum. Pere Marquette was risited July 8 and August 29, 1950; May 25 and November 29, 1951.

\section{Grafton to Cairo and Elsewhere in Southern Illinois}

\section{Chautanqua.-A small village resort} at the convergence of several ravines about 3 miles east of Grafton furnished the name for this prairic. The prairie, a part of section 13, 'T. 6 N., R. $12 \mathrm{~W}$., in lersey County, covered four south-facing spurs, mixed forest the cores. The base of each spur was a rock ledge at the top of the cliff which here closely parallels the Mississippi River. The spur slope ahove each ledge was covered with prairie; Andropogon scoparius was the dominant grass. Melica nitens occurred on the stony prairie slope above the ledge. Numerous weedy species such as Sotaria riridis, Ichillea millefolium, Ambrosia elatior, Lappula echimata, and Geranium carolinianm were present. Chautauqua hill prairic was visited July $S$ and August 29, 1950; also May 25, 1951.

Principia.-A college furnished the name for this hill prairic, a part of the co'lege campus. At this location in section 20, T'. $6 \mathrm{~N}$., R. $11 \mathrm{~W}$., east of Elsah, Jersey County, the bluff of the Mississippi River has a high limestone cliff that is capped by a mantle of loess. The cliff is not a simple wall, but has sharp salients projecting well beyond the loess spurs above them, fig. 19. Prairie, with an arca of $t$ acres, predominated on the spurs in 1950 and 1951. Andropogon scoparius was the dominant grass: Sporobolus asper was locally abundant. Several paths used by students traversed the spurs and the crest of the ridge; elsewhere the prairie was undisturbed. The lower parts of coves supported mixed forest. Above this forest. tree scedlings and Rhus glabra occurred scatteringly to the top of the ridge, fig. 20. The north side of the ridge was mell forested. Princinia prairie was visited April 21, May 23, July S, and August 29, 1950; July 5 and Norember 29,1951 . 


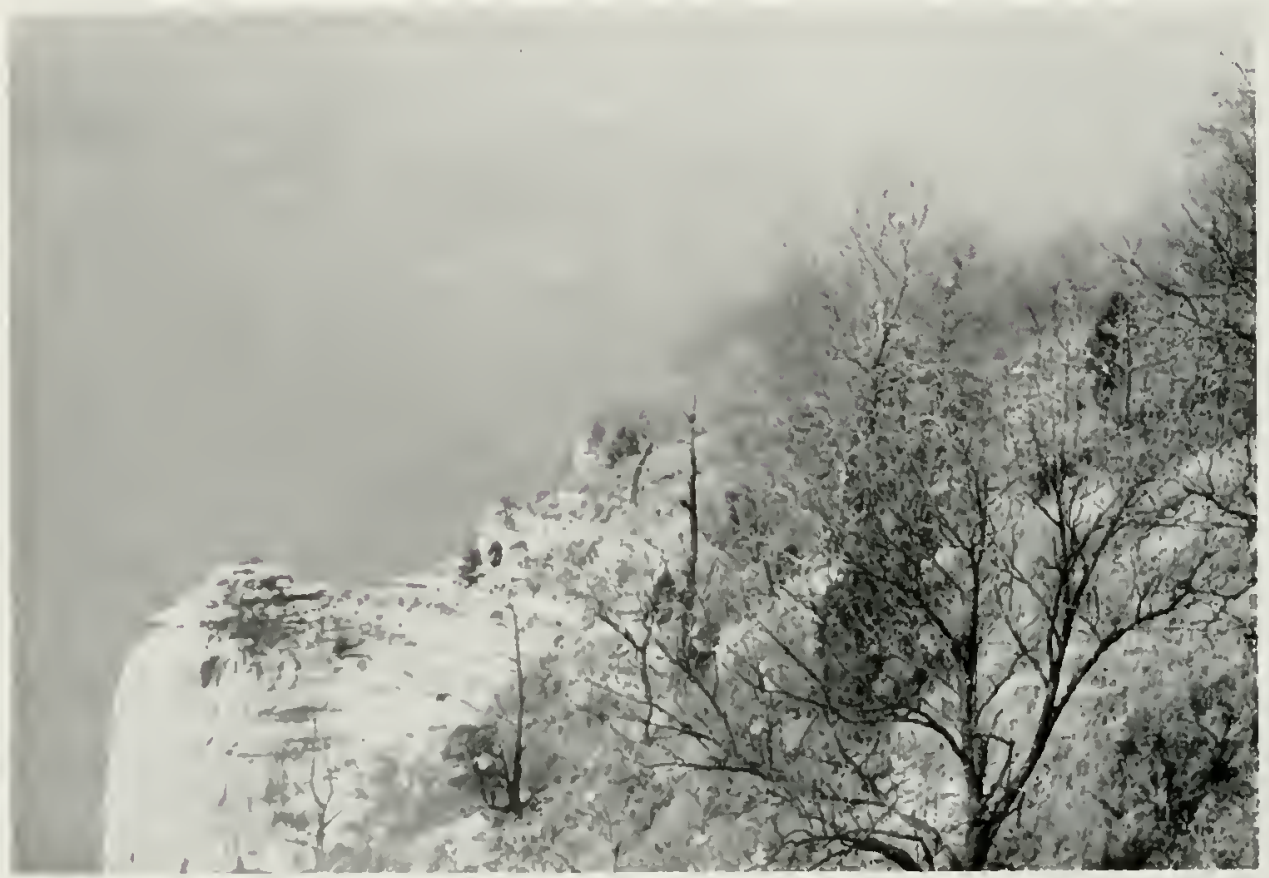

Fig. 19.-Part of the clift at Principia, near Elsah, Jersey County, with sharp rock salients that project beyond the spur fronts above.

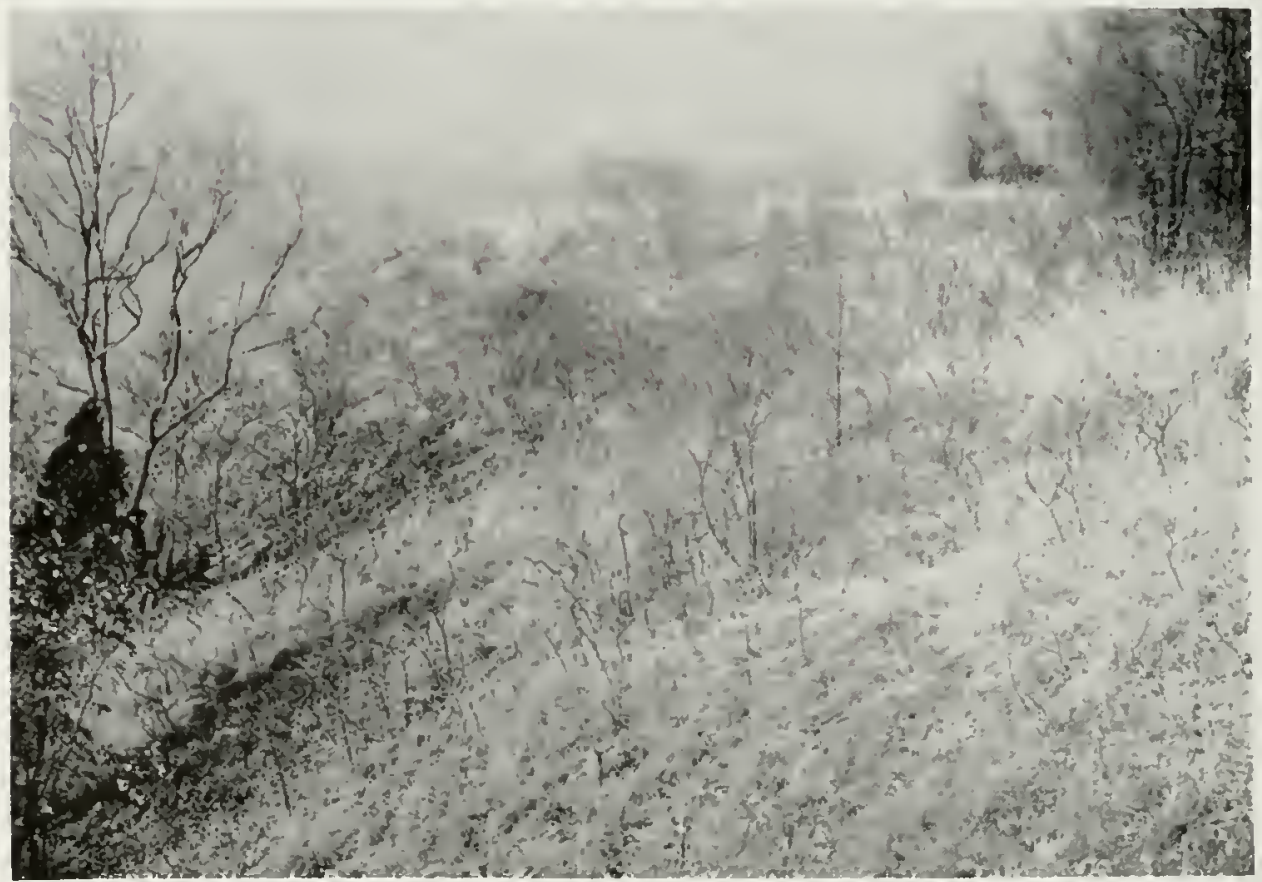

Fig. 20. - An upper slope of a cove of Principia hill prairie with a mixture of prairie plants. Rhus glabra, and small oaks. 
Oblate Fathers.--This name, taken from the mailbox at the entrance to the property on which the prairie is located. was adopted to designate a much-disturbed hill prairie situated in the northeast quarter of section 5. T. $5 \mathrm{~N}$., R. $10 \mathrm{~W}$. between Alton and Cliton Terrace. Madi- ridge between 11 linois highway 157 and the Collinswille road just north of Caserville in St. Clair County was the site of this hill prairie. The name of this prairie was derived from the presence of abandoned concrete hunkers along the highwar. The site was risited July $S$ and

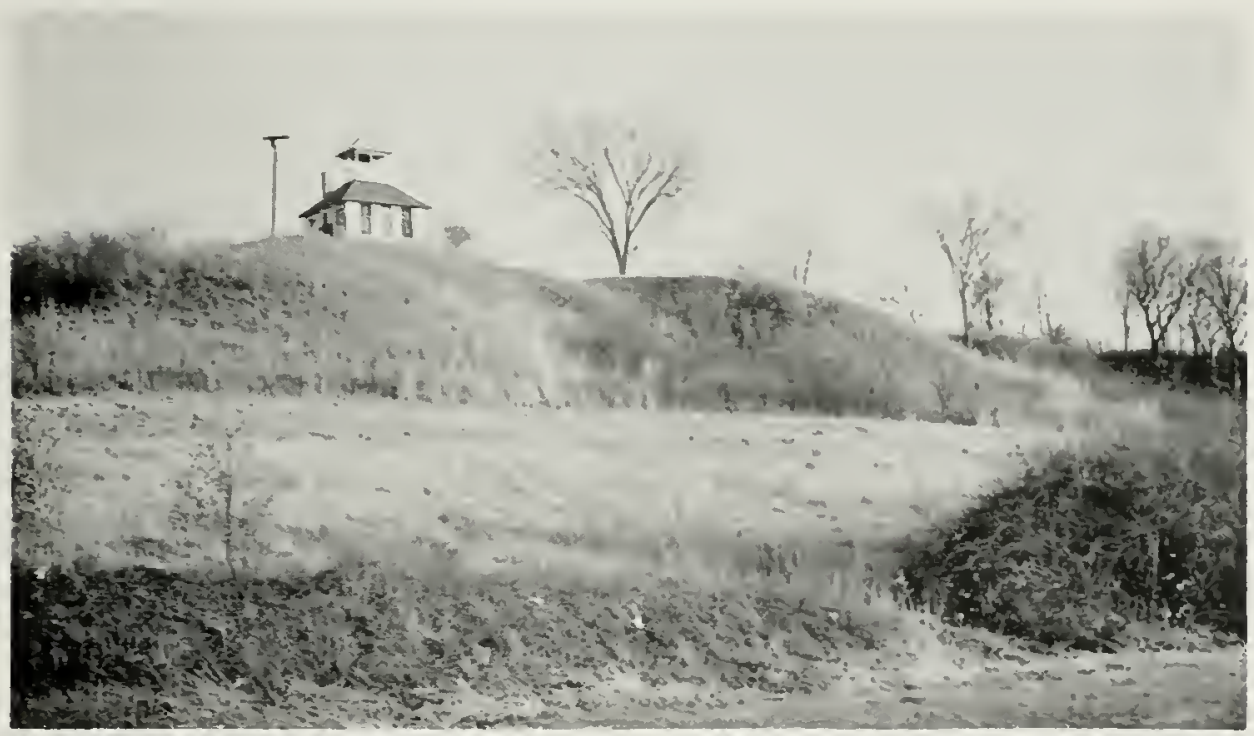

Fig. 21.-Block House hill prairie, near Glen Carbon. Madison County. In the foreground is a cultivated field, beyond which are prairie spurs.

son Countr. When this site was risited on July 25, 1951. prairie with many weeds covered about 3 acres of the southwest-facing bluff slope that served as a pasture for horses.

Block House.--Responsible for the name of this hill prairie was the shape of a small house on the b!uff-top in the northeast quarter of section 32. T. $+\mathrm{Y}$. R. S IV.. west and north of Glen Carhon. Madison County, fig. 21. Block House was visited Ju! $S$ and August 29, 1950: also 11 ar 2t. 1951. Here the bluff was seen to be deep loess, with no visible rock outcrops. The lower slope of the bluft bordering the highway was a cultivated field; the upper slope had prairie-corered spurs and thicket-covered coves. Andropogon scoparius was the dominant grass. The rop of the bluff was a disturbed prairie.

Bunker.-A group of loess mounds in section $5, T, 2$,. R. S W., that form a
Aueust 29, 1950; also May 2t, 1951. The eatt-facing slope of the ridge supported a mised forest. On the west-fac. ing slope of the ridge were prairie spurs, much disturbed by mules and cattle that grazed this land. The steep spur-fronts were prairie, the coves more or less wooded. One small core contained much prairie regetation, including Silphium integrifolium, Iernonia missurica, and Cacalin atriplicifolia. A thicket corered the base of the slope.

Edgemont.-This hill prairie, located in the southeast quarter of section 20, 1 . 2 N.R. R. $9 \mathrm{~W}^{\circ}$. in Edgemont, a suhdivision of East St. Louis, in 1940 occupied t acres of the bluft slope as determined hy planimeter from aerial photographs. Indropogon scoparius, I. gerardi, and Boutelosua curtipendula were some of the prairie grasses on this slope when the prairie was risited on September 2, 1949. This prairie, because of its location, is rapidly 


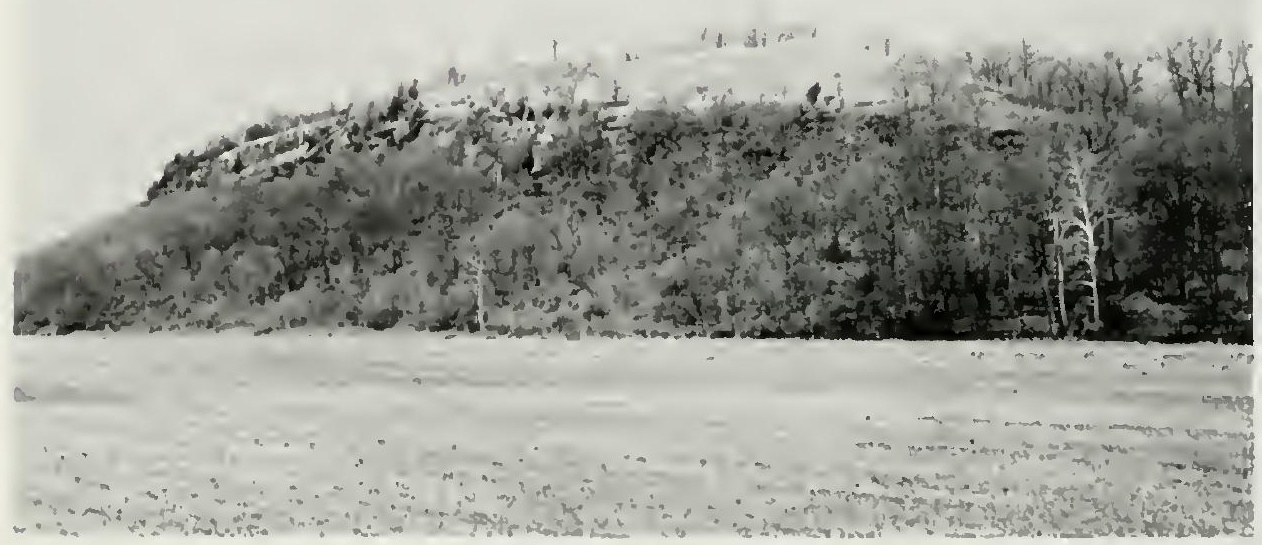

Fig. 22.- Valmeyer hill prairie, 3 miles south of Valmeyer, Monroe Couny.

being destroyed and replaced by lomes and lawns.

Southwest Edgemont.-A very small hill prairie occupied a part of the bluff in section $t, \%, 1$ X., R. 9 W., southwest of Edgemont, when this area was visited September 2, 1949. Andropogon scoporius was found with other prairie plants on this bluff.

Sugar I oaf.-This name is on the Calokia slieet of the topographic map for that part of the bluff 1 mile south of Dupo, St. Clair County, that was visited July 9, 1950. Prairie, with Bouteloua

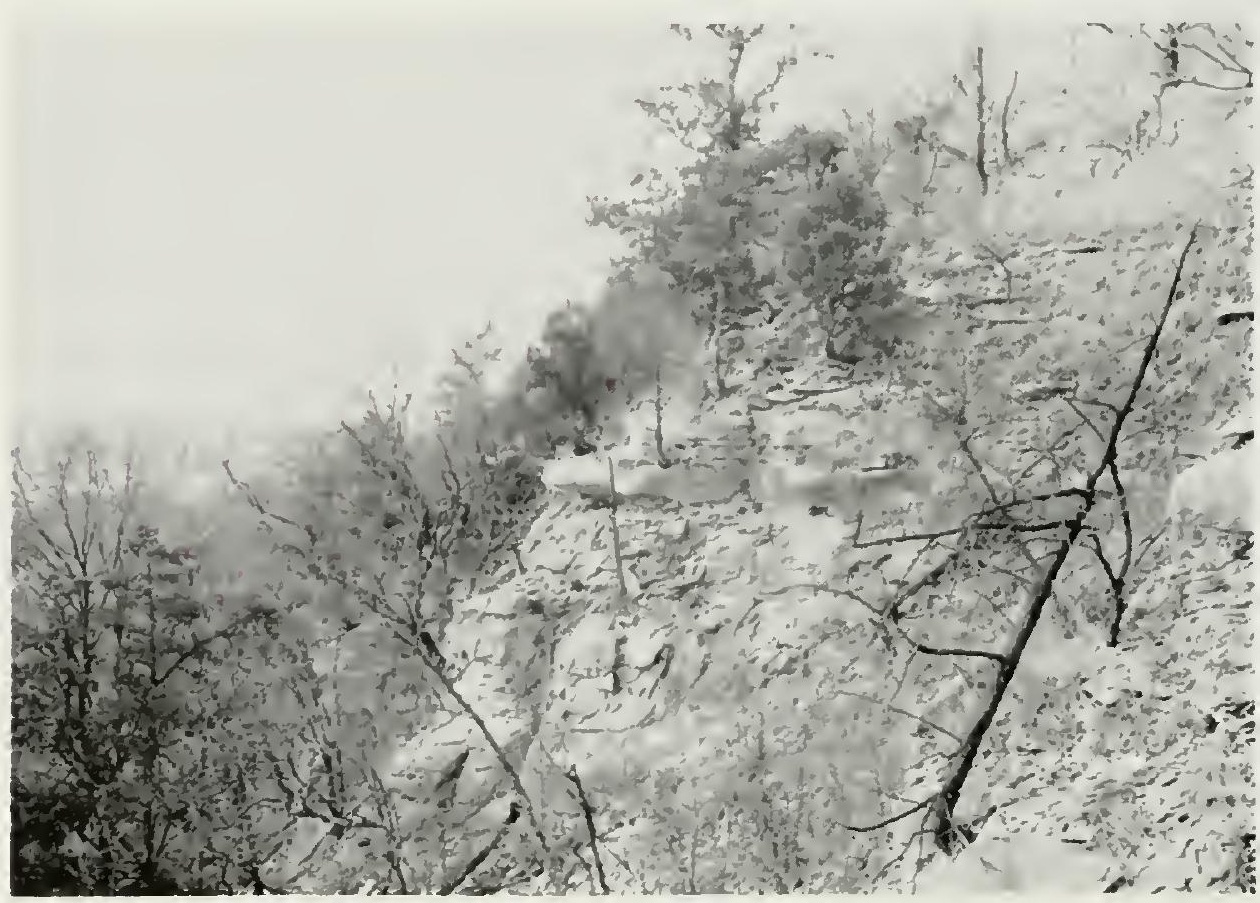

Fig. 23.-Part of the eroded cliff at Valmeyer hill prairie; prairie visible at upper right. 
curtipendula locally abundant, corered both the rocky lower slope and the loes: which capped the bluff. The loess had been hadly disturhed by earth-moving op. erations to provide level homesites.

Valmeyer. When visited, this hill prairic occupied the southwest-facing was risited. An open mixture of trees and shrubs, with much Juniperus qirginiana, surroumded the prairic openines, fin. 24. South along the hlufts large spurs were completely covered by prairic. The entire loess slopes, with no visible ruck outcrops. served as pastureland. "This site was vis-
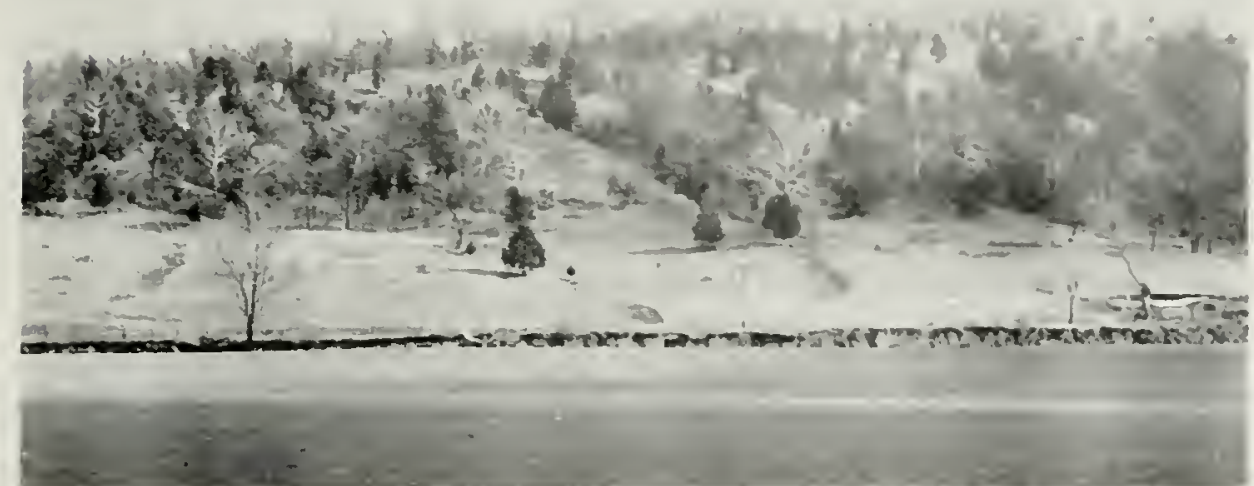

Fig. 24.-Prairie openings at Chalfin Bridge, Monroe County. Prairie is visible on the parallel ridges between row of red cedars which grow in the cove.

slope of the ridge north of Monroe City Hollow about 3 miles south of $\mathrm{V}$ almever. Monroe County, fig. 22. "The site was risited Sejtember 2, 1979; April 22. MI 24. July 9. and August 30, 1950. Prairie covered almost 9 acres of the upper slope between the clift and the crest of the hluft. thove the eroded cliff. fig. 23, the slope was stony; the upper part was loess. The east-facing slope at the highest part of the ridge supported a mixed forest; farther south along the ridge, prairie covered the upper east-facing slope and a mixed forest occupied the basal part of the slope; at the southernmost part of the ridge only mixed forest occurred. In some places the rock outcrops were merely small vertical drops separated by steep roch! slopes on which much Juniperus itirginiana grew. In the prairie above the rocky slopes, Andropogon scoparius was the dominant grass; Psoralen tenuiforn was commion.

Chalfin Bridge.-Prairie openings occupied the blufts southeast of Chalfin Bridge, Monroe Courty, when this area ited August 30, 1950, and visited and photographed Fehruary 6, 1952.

Fults. - This hill prairie located on the hlutf south of Fults Creek, southeast of the village of liults in .Ionroe Counts. Was visited September 11, J948; June 10 and August 30, 1957) also May 24, 195I. It occupied about I 2 acres, estended 0.6 mils along the upper southwest-facing sope of the hluff-ridge, fig. 25. On the northwest part of the hluff-ridge, long prairie spurs descended from the bluff-top to a small rock outcrop with a vertical face 2 to 3 feet high, below which was a forest-covered rocki slope that formed the lower third of the hluff. "Ihe coves between the long prairie spurs supported a mived woodiand. On the southeast part there was a high limestone cliff, and above it prairie covered buth spurs and coves, irhich were there very poorly defined. Galium ingulum and Heliosropium tenellum, rate in Illinois, grew on the limestone ledge.

Renault.-I,ocated about 2 miles south of Renault, Monsoe County, this prairie 
when last rivited extended about 0.7 mile along the bluff-ridge and occupied almost 14 acress of which 5 were studied. "1here was very little level area just above the rock ledge; the steep losss slope abruptly ended at the eliff. Indropogon cupied the coves. Juniperus qirginiann, Ouercus muhlenbergii, and Carga texana grew on the narrum bluff-top ridge. "The east-facing slope of the ridge wals a fairly. productive pasture, presumahly once wooded. The prairic spurs were grazed,

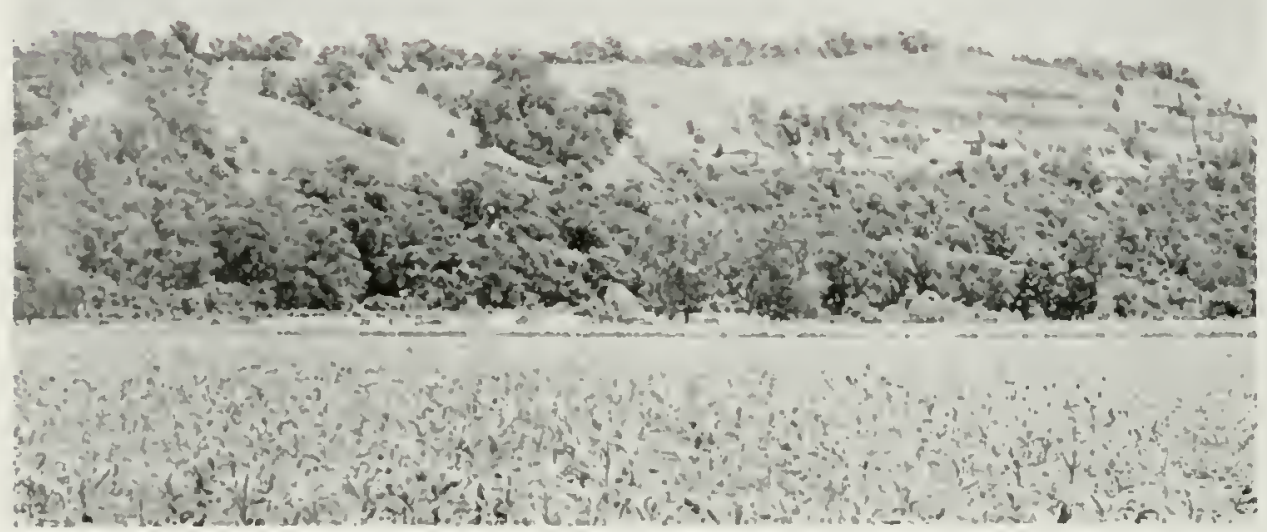

Fis. 25.-Fuls hill prairie, southeast of Fuls, Mouroe County.

scoporius wals the dominant wrass. Renault was visited July 30, 1950, and .May 2+. 1951 .

Phegley:-The appellation for this prairic came from the name of the formes tenant and caretaker, M. 11. Plesley. In 1950 and 1951, the prairie occupied 6.33 acres of the southwest-facing slope of the bluft-ridge above the Columbia (Solvar) Quarry, 1.1 miles north of Prairic du Rocher, Randolplo County.

The lower part of the brow slope above the limestone ledge at the top of the 200 foot alift, fig. 26, was covered with tragments of limestone. Prairie occupied this almost level stony surface. Which measured about 10 to 15 feet in width. Loess covered the bluff above this surface. This mantle of loess was dissected to form a series of spurs and coves, tig. 27. "The spur fronts were steep, the upper slopes gently sloping upward from the fronts to the top of the bluff.

Prairie, with Andropagon scoparius as the dominant grass, covered the spurs; prairie, forest, or a mixture of both oc- thougl apparently less closely than the main part of the pasture. 'The principal results of grazing on the prairic spurs were the thiming of the native corce and the introduction of a few weeds.

Pluts were staked on this and the adjacent prairie toward the nortliwest to furnish data for vegetation studies of this report.

Phegley hill prairie was visited June 15. July 29, and September 19, 1950; Ia) 23. September 18. October 9-10, and Octoher 16-18, 1951.

Sampson. - The name applied to this urairie was that of the farmer on whose land the prairie occurred. Sampson hill prairic, $t .5$ acres in area, was actually a continuation of the Pluegley hill prairic, from which it was separated hy two parallel wire fences, 3 feet apart, an effective barrier against grazing cattle. The Phegley prairie served as a pasture; the Sampson prairie was not grazed. Located to the north of Columbia Quarry, the Sampson prairie was similar in most features to the Phegley prairie. However. 


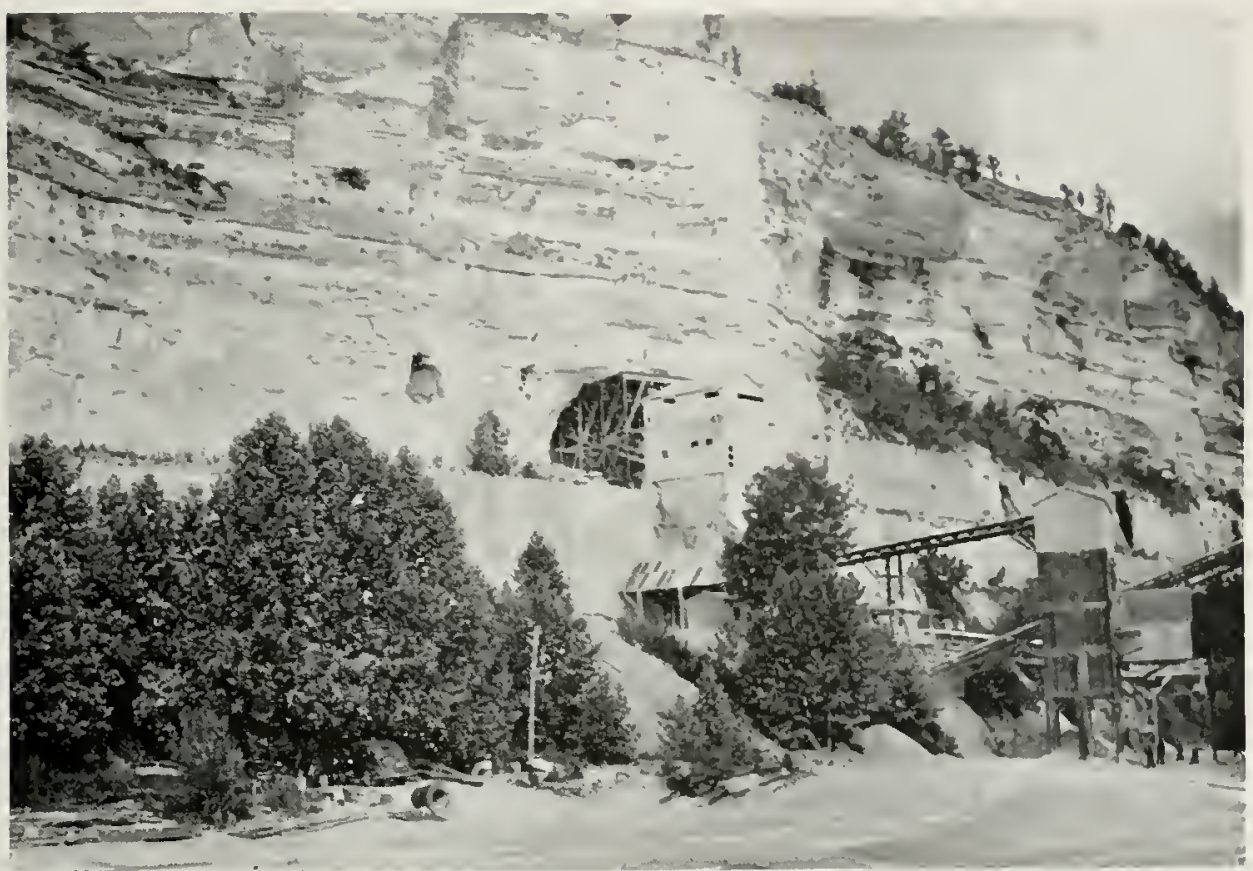

Fig. 26.- The cliff at the Columbia (Solvay) Quarry, north of Prairie du Rocher. "The Phegley hill prairie occupies the slopes above this cliff. The spurs and coves shown in fig. 27 are located above the cliff near the right edge of the picture. Sampson prairie is to the north (left) of Phegley prairie.

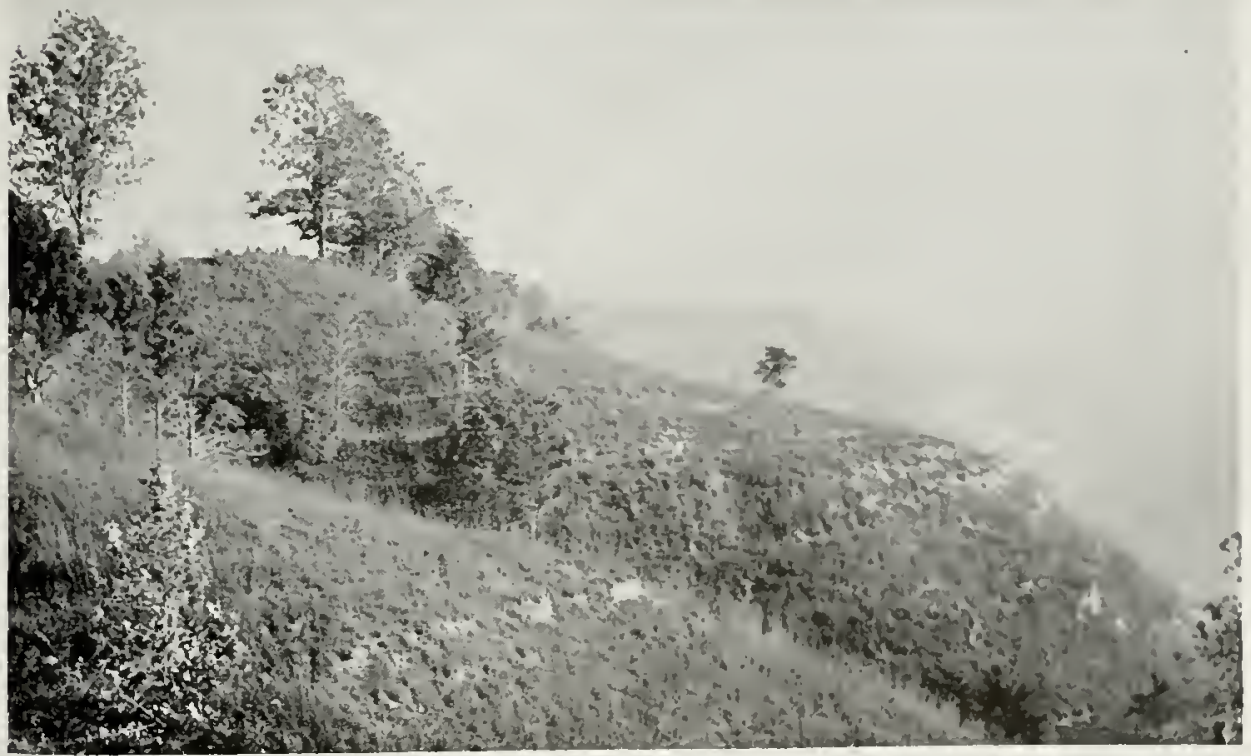

Fig. 27.-A part of the Phegley hill prairie north of Pricie du Rocher. A small cove is visible in extreme lower left corner, a larger one near center of picture between wo large spurs, which are plainly visible. 
the bluff-top ridge and the east-facing slope of this ridge were forested, except for some cleared areas serving as fieldi for cultivated crops. This prairice was visited on the same dates ats Phegley.

Stotz. - This hill prairie took its nume from a guarry about a half mile north of Prairie du Rocleer. Eight spurs of a bluffridge comprised the prairie, which corered about 6 acres in 1950; intervening ravine; were wooded. The southermmont sing had been much trampleel by humans, the others pitstured. Native plants and weeds accursed on the pastured spurs in nearly equal proportions; the native plants persinted beter on the nonpastured spur than on the others. Indropogon sopporius was the dominant grass of the prairie slopes. Patcher of Bontelound curtipendula grew throughout the prairie. 'The urchiel Hexalectris spicata was foumel in the wooklland border at the base of one spur. Stoty prairie wats risited Mla 24 and July 30, 1950.

Allen I ake.-A small, crescent-shaped lake located near a loess-capped bluff-top supplied the mame for this prairie, which was visited July 29, 1950 . "Ihe prairic wats west of the lake and 1.2 miles soutl of Prairie du Rocher. Prairie occupied t.5 acres of the upper slope of the bluff. l.imestune framents covered the lower part of the slope. 'The dominant grass was almdropogon scoparius.

South Prairic du Rocher,- When visited June 16, 1950, this very small, mastured hill prairic occupied a part of the bluff 1.6 miles south of Prairie du Rocher. Indropogon scoparins was the dominant grass. Cacalin tuberosa was found growing in the loess.

Grand Canyon.-In 1949, this small prairie opening in section 2, , T. 10 S., R. 3 II., 8 miles southwest of Murphysboro, Jackson County, occupied a west-facing slope at the north end of the bluff called Chalk Bluff, just south of the moutl of the valley known as Grand Canyon. Andropogon scoparius was the dominant grass. Small trees of hickory, sassafras, and white oak were seattered throughout. Grand Canyon prairie was visited October $28,19+9$.

Fountain Bluff.-This hill prairie, observed in 1950 and 1951, took its name from the isolated upland known as fountitin Bluff, which has a dissected loess top and for the greatest part vertical sandstone walls and is situated between the Mississippi River and the broad bottoms of the Big lluddy River west of the main chain of bluffs in western Jackson County. This isolated mpland extends 4 miles north and south, and is 1.8 miles across at the widest part. Prairie-covered slopes were oberved in section 36, T.9. S., R. 4 $1 V^{2}$, at the northern end of fountain Bluff, a distance of about 1 mile west and a little south of Gorliam.

"The northern and northwestem side uf Fountain Bluff is an almost vertical samdstone wall into which a sizable ravine has cut southeast and then castward -o that part of the ravine is almost parallel to the : teep northwest wall. A sizable ridge lies hetween the ravine and the Mississippi River hottomland on the north. (O) this ridge were the prairie-covered sopes, described in detail below.

Ahore the vertical rock cliff which forms the northeast wall of the ravine are four rock-strewn spurs, which at the time of this study were covered with prairic plants; Indropogon scoporius was the dominant gralss. These prairie-covered spurs were separated by three narrow belts of woodland in shallow draingeways. The three narrow belts of woodland were joined upslope to form another and larger belt of woodland, at right angles to the three; the larger belt covered a rock-strewn slope.

Upslope from the rock-strewn slope, the bluff is capped by loess. Three spurs on this highest exposure of the ridge were occupied by prairic, the intervening coves by small trees and shrubs. One spur faced almost westward, orerlooking the Mississippi hottomland, the others southwestward. The westward-facing spur was separated from the others by a narrow belt of timber. At the ridge-top, the prairie areas of the two southwest-facing spurs were connected to form a $U$-shaped hill prairie with the prongs of the $U$ extending downslope.

When visited June 14, August 17, and September 19, 1950, and April 19 and IIay 23, 1951, prairie occupied about 3 icres of these spurs. 
Government Rock.-Located in the southeast quarter of section 9. 'T. $11 \mathrm{~S}$. R. $3 \mathrm{~W} .+.5$ miles north of the rillage of Wolf Lake. Union County, this hill prairie. when visited, occupied one of the sizable spurs which extends from the summit downslope to the rock cliff in that portion of the Misisippi bluffs known as Pine Hills. The appellation here usedGovernment Rock-is the one applied to this spur on the Wolf Lake sheet of the topographic map.

Abore the clift at the base of the spur is a steep west- and southwest-facing slope strewn with chert stones. When last seen, the lower part of the slope was occupied by a thin stand of undersized trees. Above this was prairie, dominated by Andropogon scoparius and Boutelout curtipendula. A few small trees of Quercus muhlenbergï, Ostria sirginiana, Juniperus sirginiana, and Tirburnum rufiduium occursed in several open groups within the prairie.

Upslope on the spur was a strip, about 20 feet wide, with fewer prairie plants and an abundance of Tephrosia zirginiana. This strip was followed by a zone of mixed upland forest. which included Quercus muhlenbergii, O. stellaia, Sassafras albidum, Juglans nigra, Carya spp., Cercis canadensis, and some large trees as well as seedlings of. Pinus echinata. racinium arboreum and Ceanothus americanus were common shrubs.

The uppermost part of the spur, which was capped by loess. was occupied by prairie vegetarion. The narrow ridge-top had been much disturhed by pionickers. The east-facing slope of the bluff-ridge was forested nearly to the ridge-top.

Government Rock was visited October 27. 1949: August 17 and October 16. 1950; April 19 and May 23, 1951.

Tamms. - This hill-top prairie opening, about a half acre in area and located on the crest of a cherty ridge in the southeast quarter of section $35, T$. If S. R. $2 \mathrm{~W} ., 1$ mile west and 1 mile nortl of Tamms, Alexander Counts, was risited September 20, 1950. The prairie area. containing such plants as .tndropogon gerardi. Solidago nemoralis, and Helianthus diraricatus, was surrounded by a woodland of xeric oaks, hickory, and some sassafras. One of the oaks on this ridge was Ouercus montana.

Cave Creck.-When this area was last visited. a rock (limestone) hill prairie occupied part of the bluff on the east side of the contluence plain of Dutchman and Cave creeks, somewhat over a mile east of the Cache River, in the northeast quarter of section 28, T. 13 S., R. 3 E. about 5 miles south of Viennal and I.5 miles northeast of Forman, Johnson County. "The base of the blutf was wouded, but it had been much disturbed during the construction of a power line. The prairie opening above the disturbed wooded hluff base occupied about 1.5 acres of the south- and southwest-facing slope of the ridge. The prairie slope was strewn witl rock fragments which had eroded from outcrops at various levels on the slope. In some places the slope was almost a rock parement. Grasses and composites were the predominant regetation; a few small trees of Ouercus muhlenbergii, Juniterus zirginiana, Cornus florida, and Crataegus spp. Were found scattered throughout. The trees did not reach full size; after they had attained heights of 10 to 15 feet the tops lost vigor and the trees died.

Upslope from the prairie, the broadly rounded ridge was forested, but it had openings occupied chiefly by Andropogon gerardi. An interrupted limestone ledge traversed this forested surface. Nuch Nothoscordum bizalie grew in the crevices of this ledge.

Cave Creek prairie was visited June 10 , August 17, and September 20, 1950; April 18 and May 22, 1951.

\section{FLORA OF THE HILL PRAIRIES}

As a means of determining what species of plants occur in lllinois hill prairies, numerous collections were made from early September, $19+9$, to the middle of October. 1951. Many of the plant species very common in Illinois were onlected from only une prairie but their occurrence in other prairies was recorded in the field notes. Species lest common were collected from each prairie site in which they were growing. More than 
3,000 specimens were collected from the prairic areas: numerous others from the anlacent rock ledges, upland woods, wooded coves, and basal slopes of the hluffs. These specimens now furm a part of the collections in the herharim of the Illinois Satural Ilistory Survey at Urbana.

Collections and identification of hill prairie plants added several species to the known Illinois flora. Rndleckin missonriensis was one of the rare plants reported (Evers 1951). 'The collections verified the present-day existence of certain species reported over a half century agu from Illinois but not collected in the state again until the field work for this study was undertaken. Mentzelin oligosperma is a untable example. 'l'Te collections also increased the knowledge of the distribution of plants having somewhat restricted ranges in Illinois. Thus, it is now known that Boutclona curtipendula ranges almost continuously, in suitable hahitats, from northern to southern Illinois alone the Western border, that Psoralea tenurflora ranges southward into Monroe County, and that Houstonic nigricans is quite common on loess slopes in seuthwestern llinois.

'The hill prairies contain prairie, woodland, cultivated, and introduced species. The woulland species are occasionally found in prairie just as the prairie species are found in woodland, especially in adjuining border areas. The cultivated plants usually are escapes that have become established in the hill prairies. Some, Lespedeza stipulacea for example. had been planted in certain prairies or in adjoining pastures by the landowners. Asia and Europe are the original homes of 30 of the species found, North Americal of the remainder.

\section{Annotated List of Species}

This list was compiled from collection made and notes taken on the llinois hill prairies visited. Field notes were wied to supplement the distribution recurd hut no species is included in this list unless it was collected from at least one prairie. The list is not intended as a complete flora of the Illinois hill prairies. Such a compilation would require much additional time and many additional visits to these sites. In some cases, only the generic name of a plant is given. 'Thus, the four species of grapes are included in this list under the term litis sply. In most instances, both generic and specific epithets are used. Any pertinent synonym is placed within hrackets following the scientific name. Brief notes on the occurrence of each plant or plant group follow its name. The name of each plant that is of foreign origin is preceded by an asterisk (*).

Table 1t, which summarizes presence, as dincussed on pare 392 , contains a partial enumeration of the annotated list of species. Species found only on rock ledgres, in coses, or in woodland horders near, but not in, the prairie stands of any site listed in table $1+$ are not indicated for that site. Sume species mentioned in the annotated list are not included in tahle If because they are not native to North America or are not regarded as characteristic prairie species.

\section{LECIDEACEAE}

Lecidea spp. Lichens of this genus were found in It hill prairies. "Iwo sample's were identified by Dr. C. IV. Dodge of the Missouri Botanical Garden as $L$. decipiens and L. demissa. These plants grew betwcen grass tufts under the shade of the grass foliage on either loess or fine rock fragments.

\section{Marchlantiaceae}

Rebonlia hemisphaerica (L.) Raddi. 'This was a freguently encountered liverwurt on loess and rocks of hill prairies, where it grew in interspaces between bunches of grass.

\section{Musci}

An unidentified moss (or mosses) grew un loess of some hill prairies. All plants examined lacked sporophytes and accordingly remain unidentified.

\section{Selagiñ elaceace}

Seluginella rupestris (1.) Spring. The ruck selaginella yrew in the sandy hill prairie at Devil's Backbone. Although found on sandstone outcrops in southern 
lllinois (Pope County), apparently it is absent from similar situations in the Fountain Blutt hill prairie.

\section{EQtisetaceAE}

Equisetum hyemale L. The tall scouring-rush was seen in three hill prairies, Rock Island 31. Bunker, and Soutbwest Edgemont, where it occurred in loess. It was not seen on rockl slopes.

Equiselum laerigatum A. Br. [E. kansanum Schattn.] The smooth scouringrush was ohserved in seven blutt prairies. all of them in northern or central lllinois.

\section{POLYPODIACEAE}

Cheilanthes lanosa (Michx.) D. C. Eaton. The woolly lip-tern was found in rock prairie at Cave Creek. It wa more abundant. however. on rock outcrops than on prairie slopes.

Pellaen atropurpurea (L.) Link. Although the usual habitat for purple cliffbrake is calcareous rocks, it cccurred on the loose stony slopes at Care Creek and Government Rock.

\section{Pixtaceate}

Juniperus airginiana L. Red cedar was found in both rock and loess hill prairies and was common on rock ledges at the bases of prairie slopes-and in wooded cores. It was the only tree species on some of the prairie slopes. Steyermark (19+0) noted its trequent occurrence in Mlissouri glades.

\section{Gramineate}

tgrostis hiemulis (Malt.) B.S.P. Ticklegrass was encountered only in rock prairie at Fountain Bluff.

folropogon gerardi Vitman. [.t. furcatus Mubl.] The hig bluestem is an abundant prairie grass in Illinois. It was observed in 37 hill prairies. It was found as a dominant unly in scattered paiches. and in this status in only a tew hill prairies.

Andropogon soparius Michx. Little bluestem was found to he the usual dominant and is the most important yrass of the hill prairies of lllinois.

Andropogon zirginicus L. Broomsedge, a common gras in open woods. old fields. and along roadsides in southern lllinois, was not fouml to be an imporiant -pecice of the hill prairies, having been sen in but one. Fountain Blutf, on the loss pratirie slopes.

Aristida basiramea lingelm. ex laner. "lhis plant was collected in unly the Sunset Trail hill prairie.

Aristida intermedia sorihn. it Ball. This was olserved onl at Hill-lop and in the sandy prairie at Devil: Backbone.

Aristida longespica Poir. "This threeawned crass was collected in prairie it Devil's Backbone and from a ruck ledge at Care Creek.

Aristida oligantha Michx. 'This weedy species was collected in only the seehorn. Passon hill prairie.

Bouteloun istripendula (Michs.) Torr. Side-oats grama was found in ti of the hill prairies examined. In southern Illinois, it was found in Cave Creek and Government Rock prairies. bus is was not observed at "lamms. Fountain Blutt. or Grand Canron. le was seen at most of the sites examined from Allen Lake northward along the Missisippi and Illinois rivers. Vestal (19+5) mentiuned "hill prairie and sanditone clitt-tops" as common habitats of this species in IIlinuis. He ohsersed in July, 19+1. that this bouteloua dominated several steep sumthwest slopes of prairies along the lower Illinois in Jersey County, sites nut included in this study. Side-oats yrama was the dominant gras just above the ruck ledge at Swarne: a few teet higher o. the prairic slope, Andropogon soparius was dominant.

bouteloun hirsuin Lilg. Hairs grama was ohserved in ejoht hill prairies. most of them in northern lllinois. It grew in the hearily pastured loess prairie at Bald Bhtt and also along the hutis of the lllinois River at IIud Creek and Vurtheast Meredusia in central Illinoi.

Bromus commutatus Schrarl. Hairs cluess was found in loess and rock pritriu at five sites and in crevices of rock ledge at two others.

* Bremars terforam L. Down! chess or cheat was found in situations similat to those of hairy chess. It was more ahun dint in crevices of rock lealges than in hill prairie. 


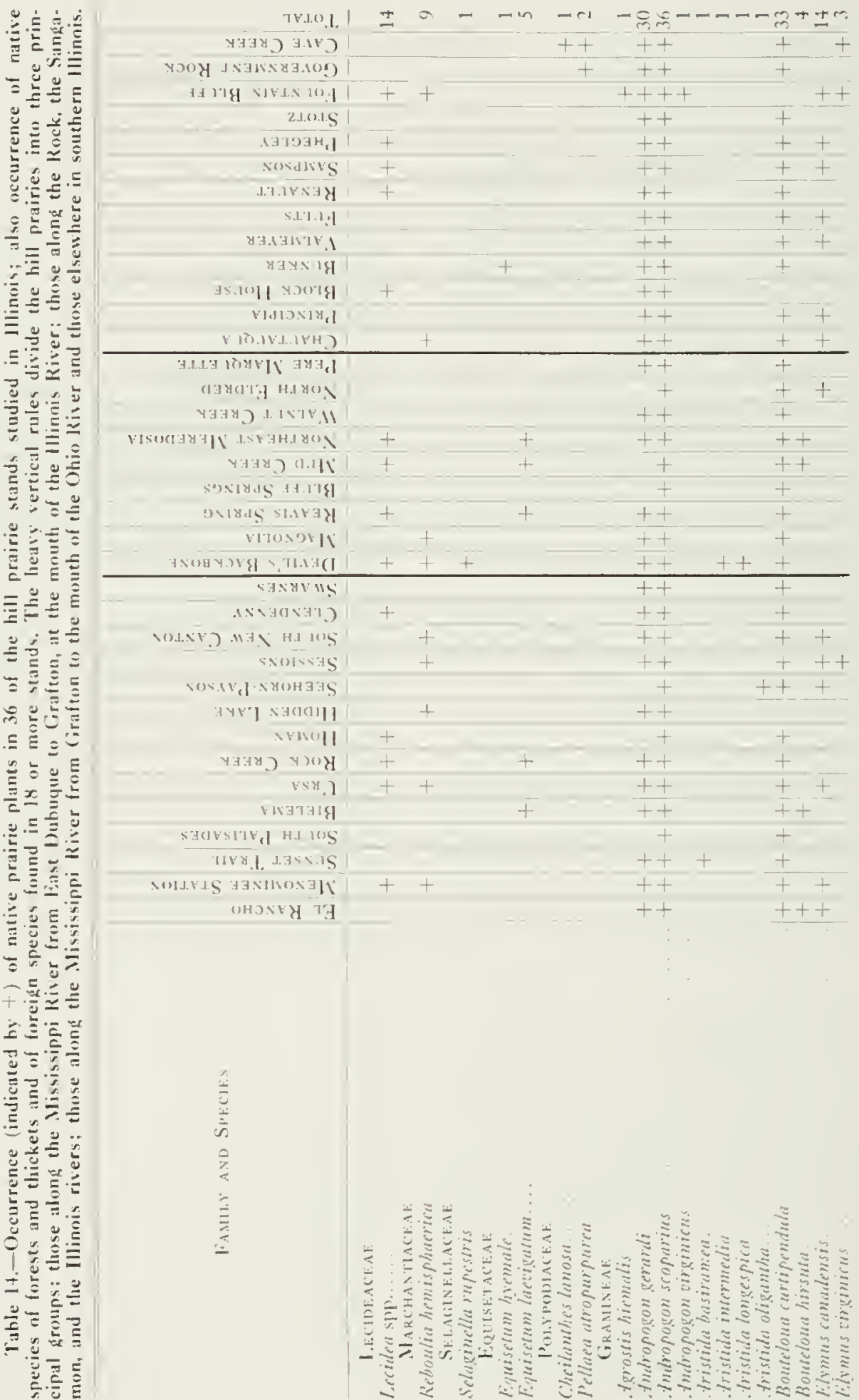




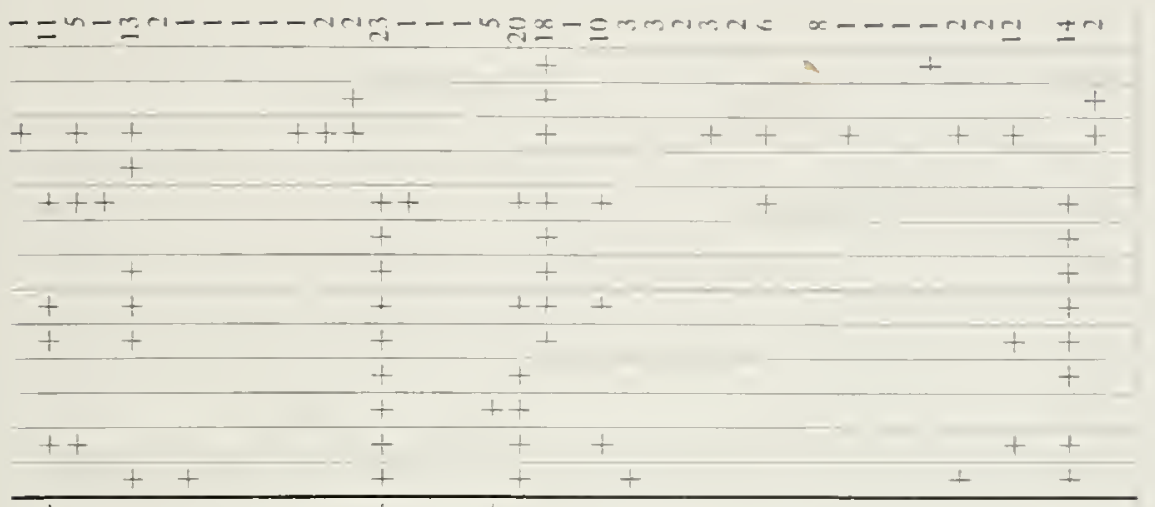

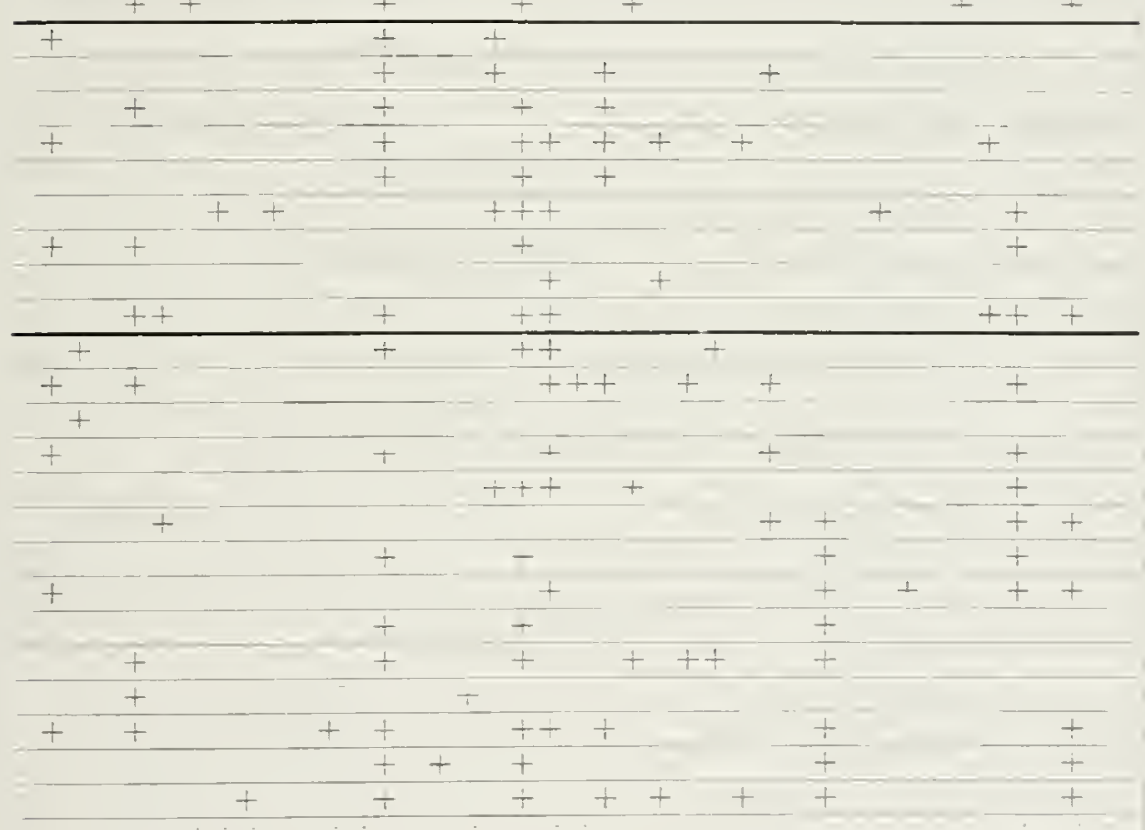

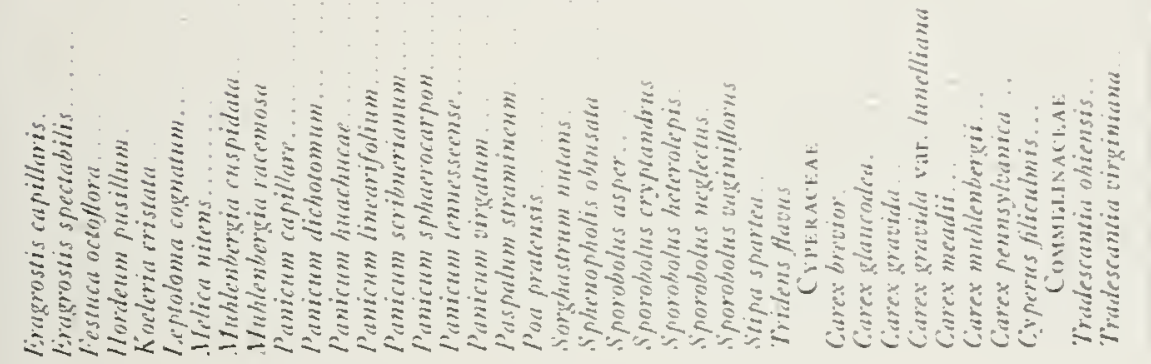




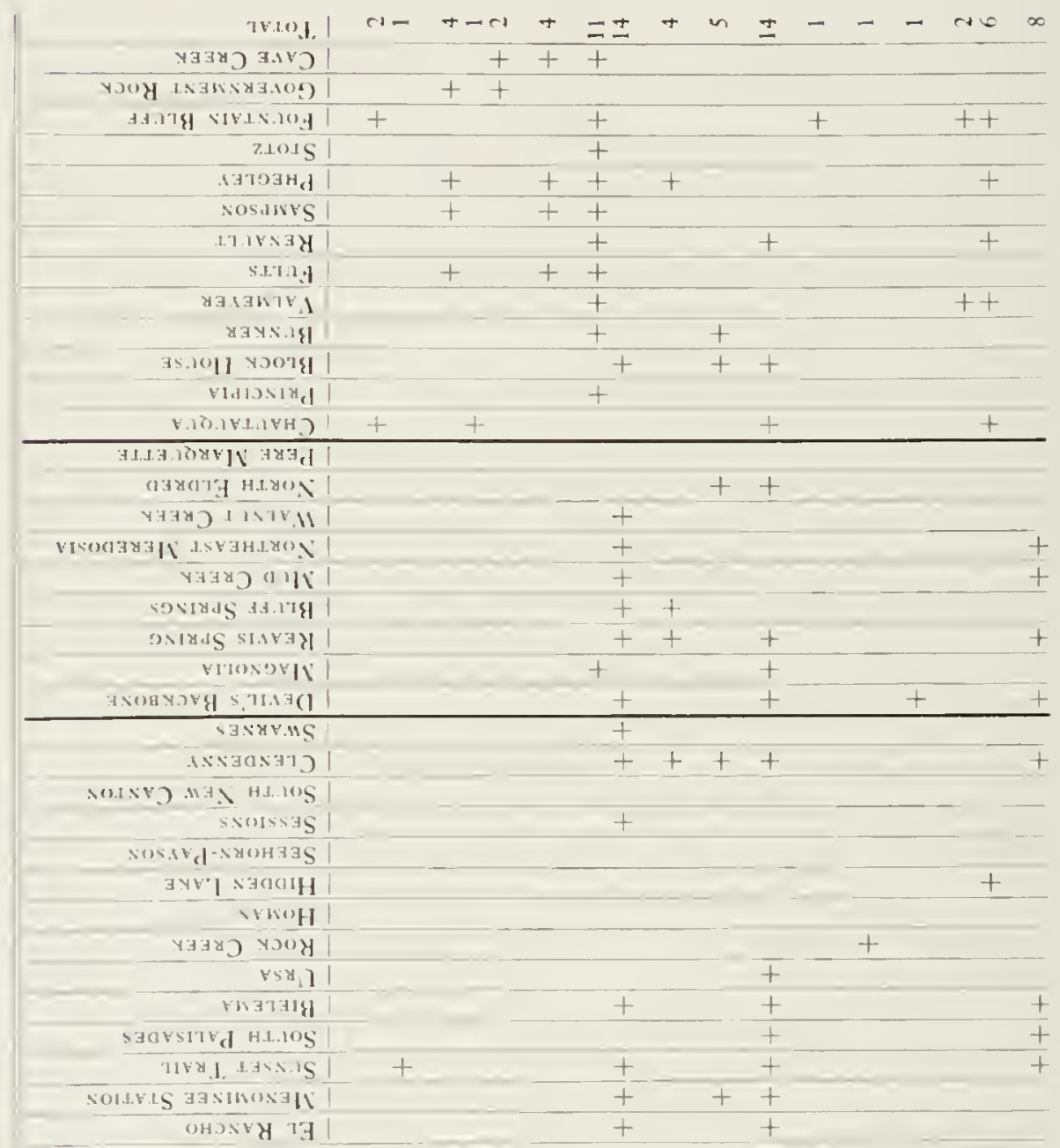

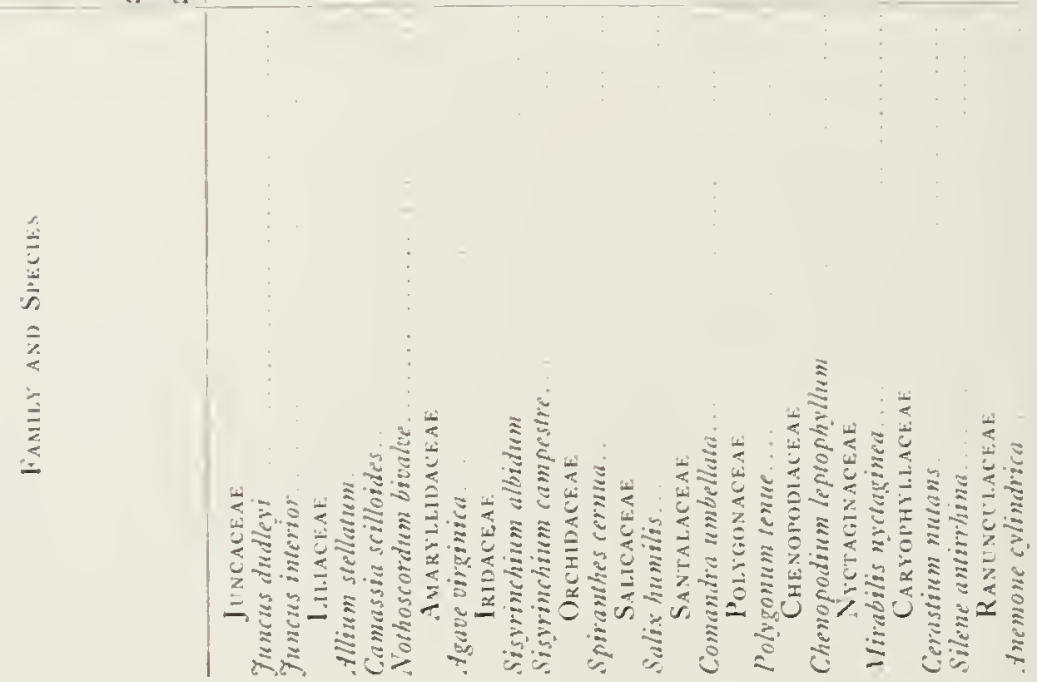




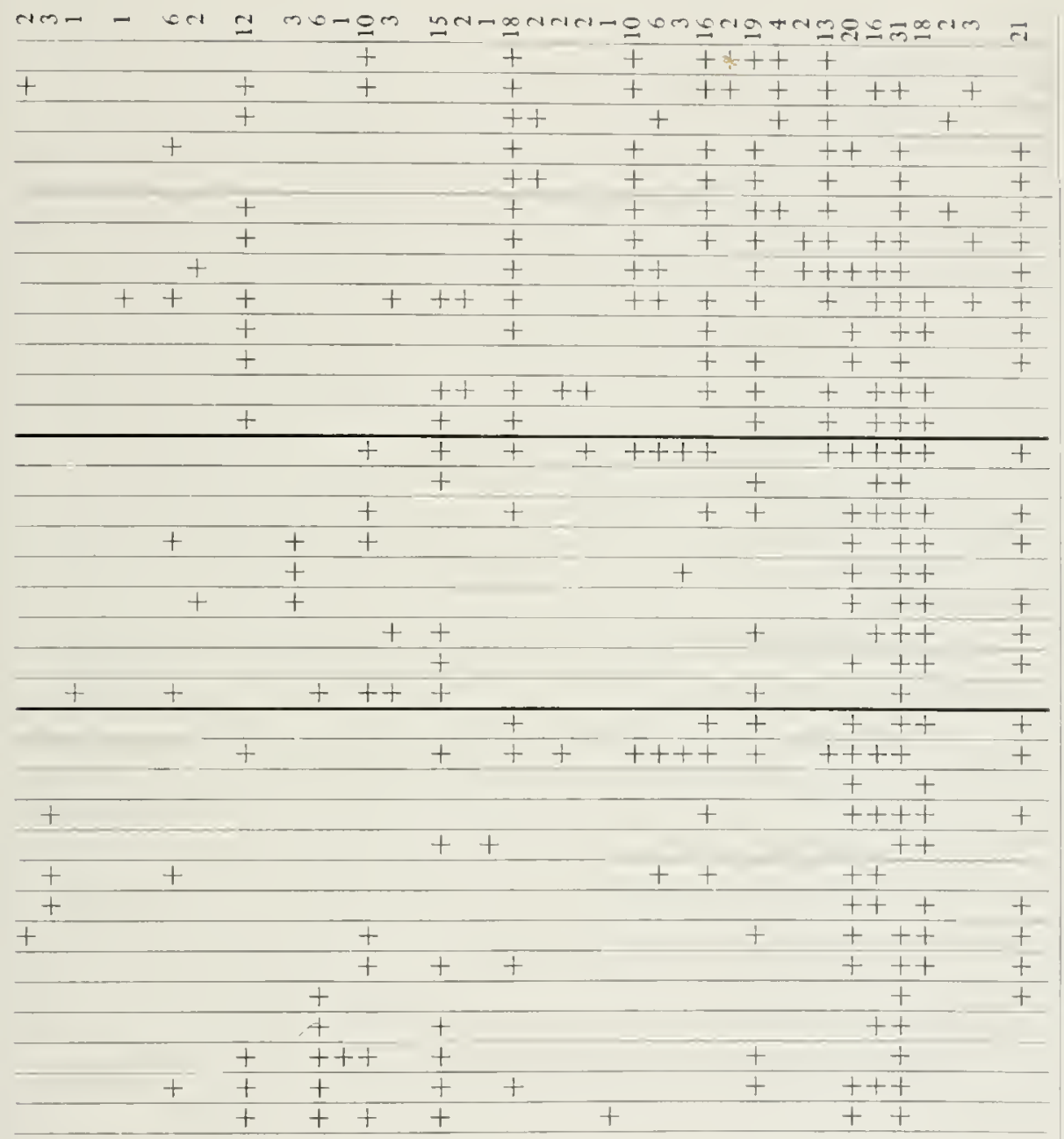

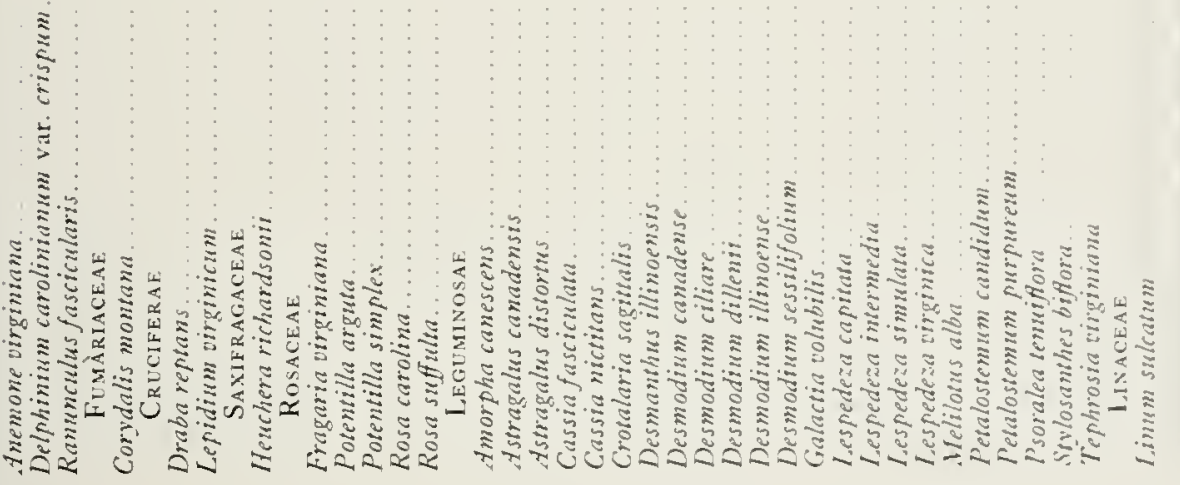


$+20$

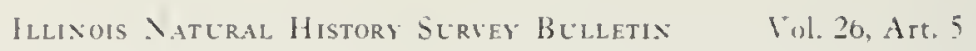

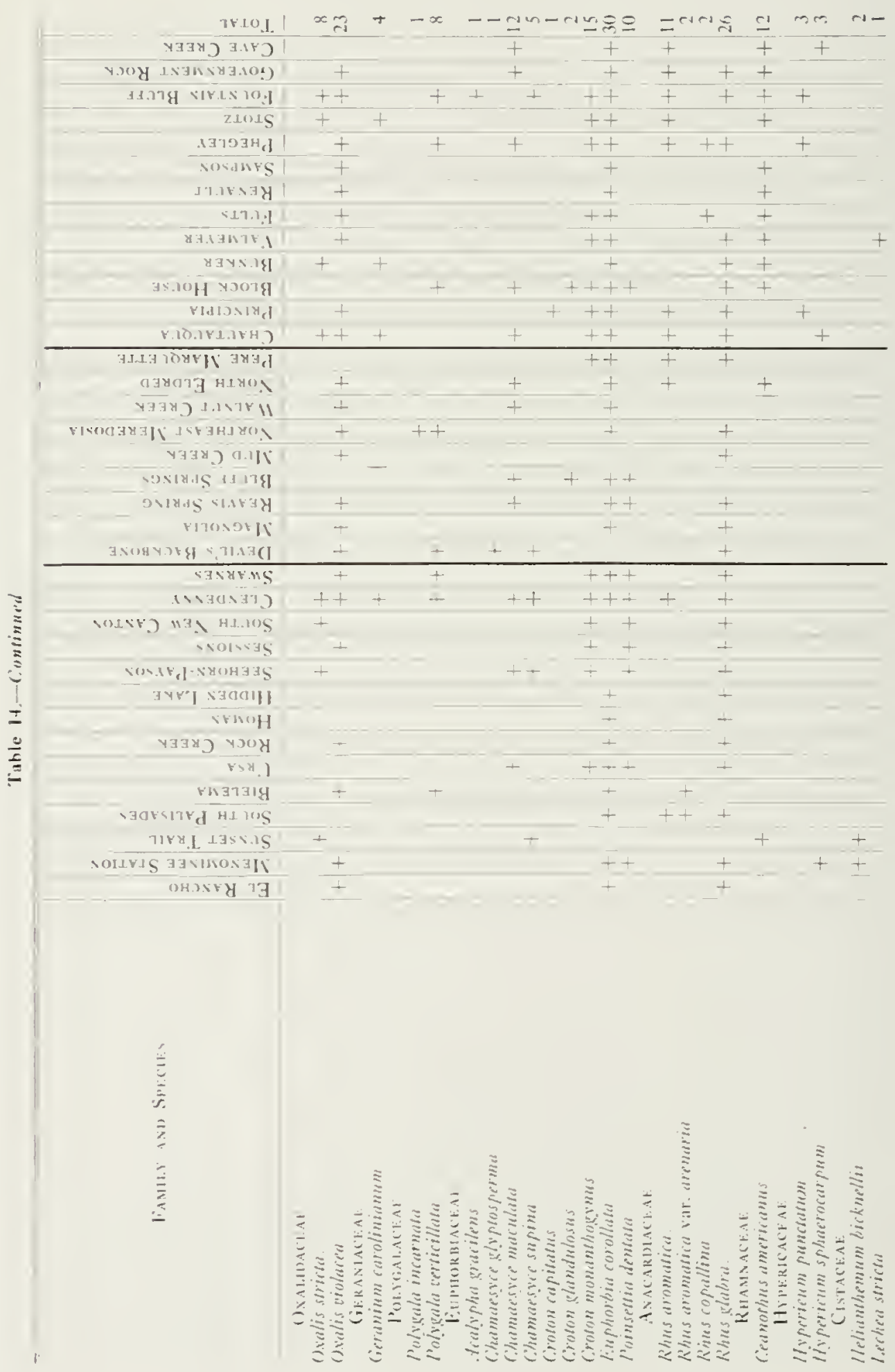




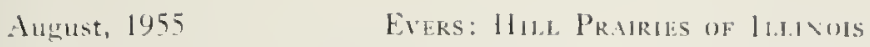

421
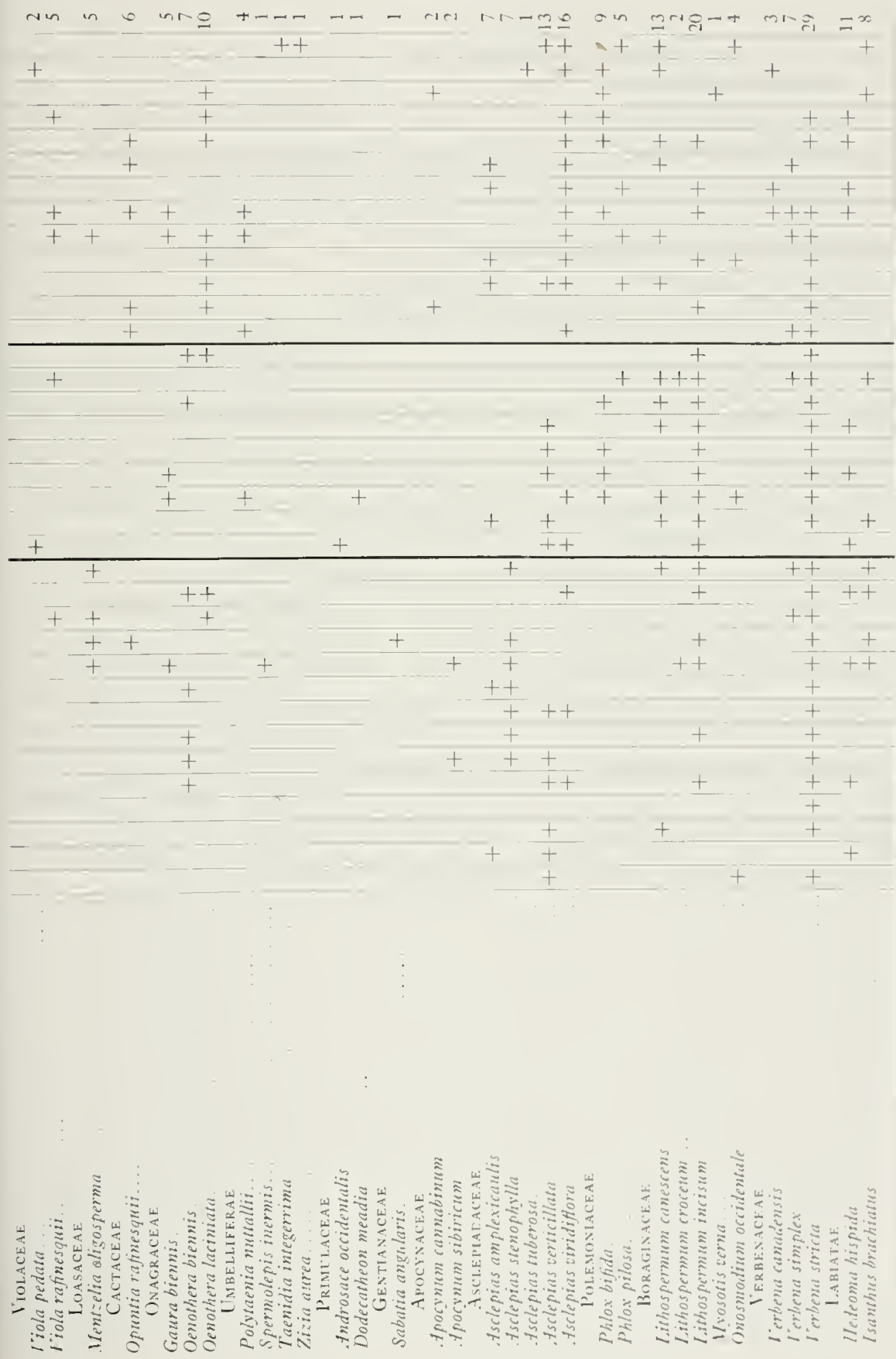
$+22$

Illixols \itural, HISTORY SURIEY BUlletiN

Vol. 26, Art. 5

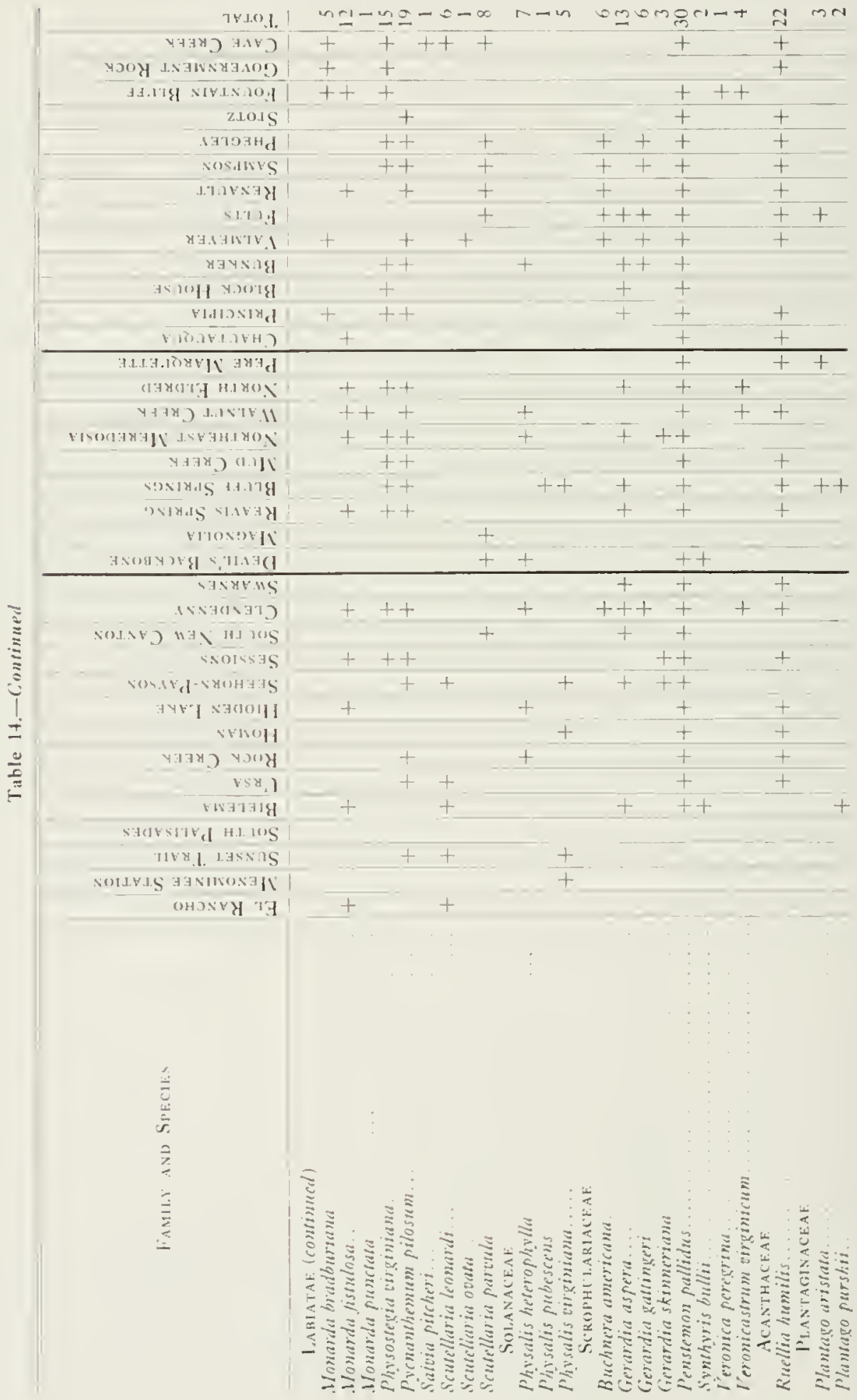



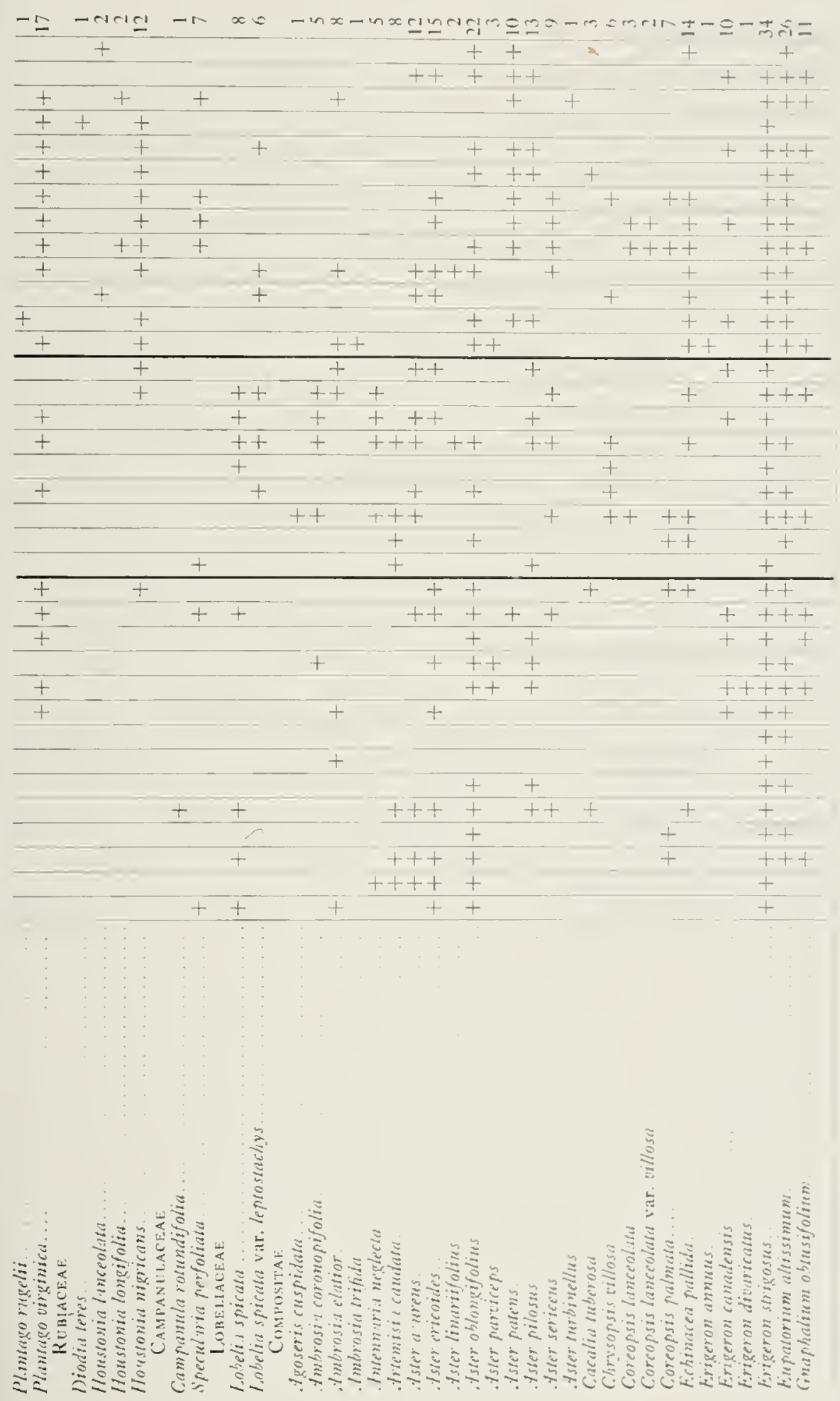
$+24$

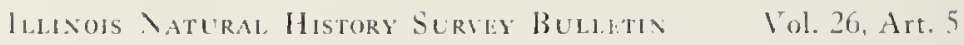

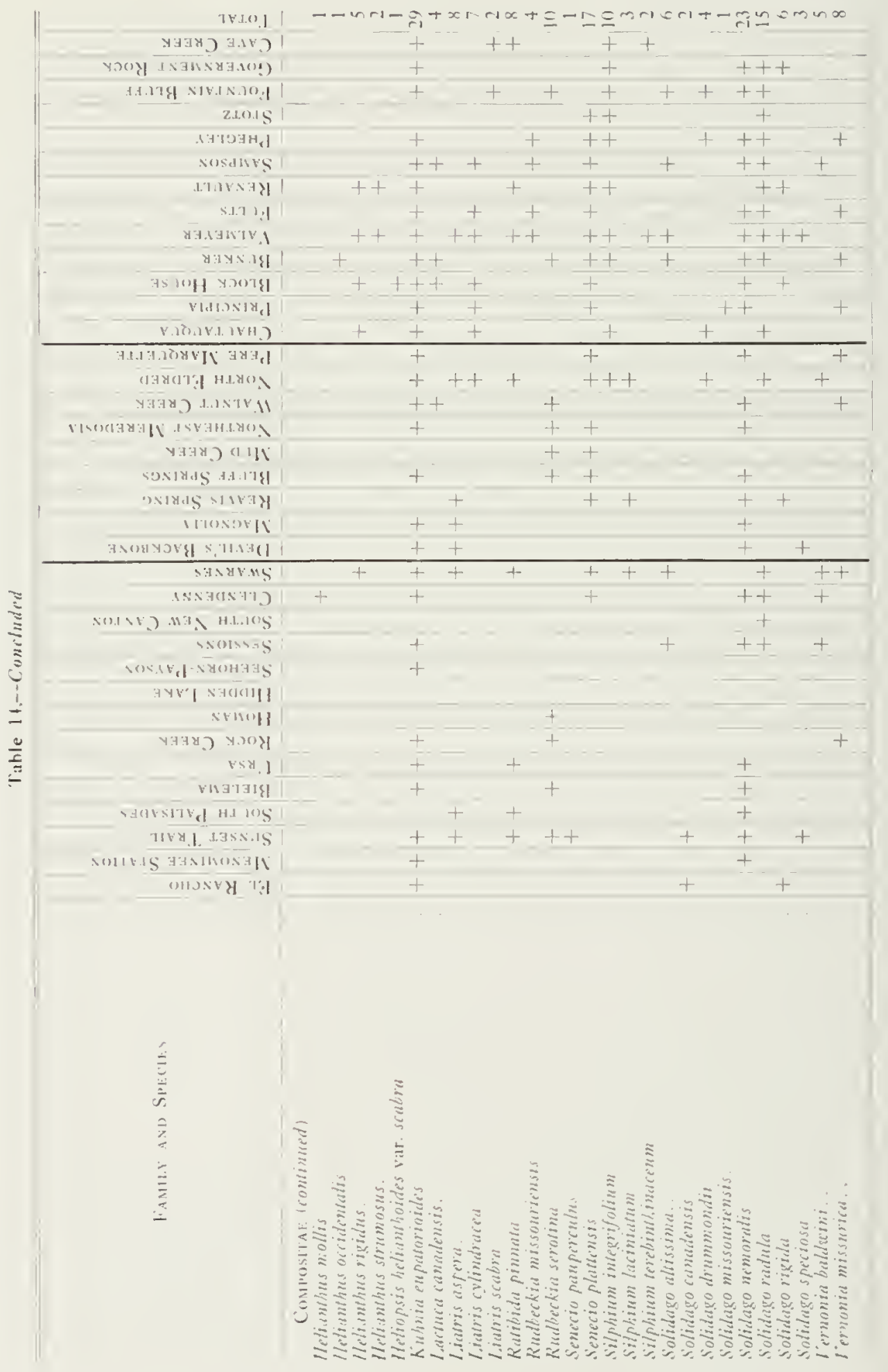


Danthonia spicato (L.) Peaus, ex Roem. A Schult. Porerty oat-grass was observed in rock prairie at Deril's Backhone. It is usually found in dry woodlands.

Elymus canadensis L. Canada wildrye was found in 16 of the 61 hill prairies visited.

Elymus itirginicus L. Virginia wildrye was found in three hill prairies. It was more common in the adjacent woodlands than in prairie areas.

Eragrostis capillaris (L.) Vees. Lacegrass, a species of fields. clearings, rock ledges, and glades, was collected trom hill prairic areas only on the rocky s!ope at Fountain Bluft.

*Eragrostis cilianensis (.tll.) Lutati. Stinkgrass was found only on the disturbed crest of the hluff-ridge at Clendenny.

Eragrostis spectabilis (Pursh) Steud. Purple lovegrass was found scattered in 17 loess prairies.

Festuca octoflora Walt. Six-weeks fescue (including the variety temella) was observed in six hill prairies, either on rocky or loess slopes. It was seen also on limestone ledges at three prairie sites.

Hordeum pusillum Iutt. Little barley was found only at Phegley hill prairie.

Koclerin cristata (L.) Pers. Junegrass occurred in scattered patches in 14 hil! prairies, but it was never abundant.

Leptolama cognatum (Schult.) Chase. Fall witchgrass more trequent in sand prairie than in hill prairie, was observed at only two sites. Hidden Lake and Devil's Backbone.

Melica nitens (Scribn.) Nutt. ex Piper. Three-flower melic, a plant of rock! woods, bluffs, and glades, was found growing at Chautauqua on stony prairie slopes, at Valmeyer and Fults on the rock ledges.

Muhlenbergia capillaris (Lam.) Trin. This muhly of rocky or sandy woodlands was found only in rock prairie at Gorernment Rock.

Muhlenbergia cuspidata (Torr.) Rrdb. Plains muhly, a plant of rocky blufts. sandy woods, and loess hills. was found only in loess at Bluff Springs.

Wuhlenbergia racemosa (Michx.) B.S.P. This species occurred on loess slopes at Wiersma, on rock-strewn slopes of El Rancho, and on rock ledyers at Fountain Bluff anü Sampson.

Panioum capillare L. Mitchgrass was observed in two hill prairies, Bluft Springs and Richwood.

Panicum dichotomum L. This panic grass was collected on the stony slopes at Fountain Bluff.

Panicum huachucae Ashe. [P. lanuginosum var. fasciulatum ('Torr.) Fern.] This prairie species of panic grast was found in five hill prairies on the bluffs of the Missisippi River.

Pantum linearifolium scribn. This species, usually of dry woods, was found on stony slopes of Fountain Bluff and Government Rock.

Panicum siribnerianum Iash. [P. oligosanthe's var. scribneriunum (Nash) Fern.] This species was seen in 27 hill prairies. mostly on loess but occasionall! on rocky slopes.

Panicum sphaerocarpon Ell. This panicum of sandy soil was collected at Phegley hill prairie in locss.

Panicum tenuesseense Ashe. [P. lanuginosum var. fasciculatum (Torr.) Fern.] This plant grew in loess at Menominee station and on stony slopes at Standard.

Panicum airgatum L. Switcherass. common throughout most iypes of prairie in lllinois. was ohsersed in hill prairie only at south Palisades and Hill-Top.

Paspalum straminesu Xash. "This species wa. found in loes of tive hill prairies.

- Poa compressa 1. Canala bluegrass occurred on two loess slopes and also two stony slopes.

Poa pratensis 1.. Kentucky bluegras. was found in more than 20 hill prairies. In some it was locally dominant hut more often cccurred scattered throughout the prairie area. It becomes dominant in pastures, and spreadi from them.

- Setaria lntescens (I'eigel) Hubb. [S. glauca (L.) Beaur.] Yellow hristlegrass or yellow fostail, was found at Hidden Lake in loes and on the rock ledges at Valmever.

- Setaria rividis (L.) Beaus. Green hristlegrass, or green foxtail, was seen on three prairie slopes. le was more common on rock ledges than in hill prairie. 
Sorgluastrum nutans (L.) Nash. Indian grass was observed in 23 hill prairies, usually in loess but occasionally on nocky slopes. It was the dominant grass in prairic at Hill-lop and also in the woorland border at North Pandarmie.

Sphenopholis obtusatu (Michx.) Seribn. Prairie wedgegrass occurred in loess at Clendenny. It was seen in woodlands adjoining other pratirics.

Sporobolus asper (Miclix.) Kunth. This dronseed was observed in 10 hill prairies. 1t was frequent in loess at Principia.

Sporobolus cryptandrus ('Torr.) A. Gray. Sand dropseced was seen in loess at Bielema, Seehorn-Payson, and Chautaqua mairies.

Sporabolus heterolepis (A. Cratg) A. Gray. Prairie dropseed was not common in hill prairie. It was ohserved on stony slopes at El Rancho and Magnolia and on loess at Northeast Meredusia.

Sporobolus neglectus Nash. This annual dropseed grew on rocky slopes at Bielema and Clendenny hill prairies. At Clendenny it grew also on limestone ledges and in the border between prairie and wooded cores.

Sporobolus a'aginiforas ('Torr.) Wood. This species occurred in loess at Bielema, Wriersma, and Swarnes, on rocky slopes and sandstone ledges at Fountain Bluff, and on limestone ledges at Phegley and Sampson.

Stipa spartea Trin. Porcupine grass, of infrequent occurrence in hill prairie, was observed at El Rancho, Balk, and Northeast Meredosia. It is commonly observed in flatland prairie.

Tridens flaz'us (1.) Hitchc. [Triodia Aara (L.) Sinyth.] Purpletop was found growing in loess at eight hill prairies in central and southern Illinois.

Unisla latifolia Michx. Broadleaf uniola, or spike grass, common in open woods in southern Illinoss, was found in the disturbed loess prairie at Government Rock.

\section{Ciperaceae}

Carex brezior (Dewey) Mack. A sedge of dry, rocky ground, this plant was collected from 10 hill prairies in northern and central Illinois.
Carex glaucodera 'Tuckerm. [C. flaccosperma var. glaucoden (Tuckerm.) Kïkenth.] This sedge was collected from rock prairie at Fountain Bluff.

Carex grarida Bailey. This common sedge was ohserved only at IBluff Springs, on the loess slope.

Carex grazida var. lunelliana (Mack.) E. J. Hermann. This variety was collected only at Rock Creek, from loess.

Ciarex moulii Dewer. This sedge wals collected on stony slopes at Cave Creek.

Carex mulhenibergit Schk. This sedge, common in sind prairie, was observed in only four hill prairies, Balk, Standard, Chautaucua, and Fountain Bluff.

Carex pennsylounica I,am. A sedge of terile soil and open wools, this species was collected at Devil's Backhone and Northeast Meredosia.

Cyperus filiculmis Vahl. The slender cyperus (including the variety macilentus), a plant of dry sindy soil, was seen in 16 hill prairies; its southernmost station was Fountain Bluff.

\section{COMMLINACHAE}

Trudescantia ohiensis Raf. [T. cunaliculata Raf.] "lhis spiderwort was seen in 16 hill prairies, growing on loess or stony slopes. Also, it was observed in crevices of limestone ledges at Stotz and South Prairie dı Rocher.

Tradescantia zirginiana L. This species, which occurs mostly in woods, thickets, and meadows, was found on the rocky slopes of Fountain Bluff and Government Rock.

\section{JUNCACEAE}

Juncus dudlcyi Wieg. This rush was ohserved in loes prairie at Chautauqua and Fountain Bluff.

Juncus interior Wieg. This species was seen growing on loess slopes at Sunset Trail and on rocks slopes at Standard.

Juncus tenuis Willd. [J. macer S. F. Gray.] 'This common rush of woodlands was observed only at Oblate Fathers, in loess.

\section{LILIACEAF}

Allium canndense L. Wild garlic was seen in loess at Oblate Fathers and Allen Lake. 
filium stellatum Ker. This wild onion was found on rocky slopes at Govern ment Rock and on loess slopes at Fults, Sampson, and Phegley. Its occurrence on loess and stony slopes was nowhere so abundant as on rock ledges at the bases of these slopes.

* Allinm imenle L. Field garlic was found in two prairies, Sugar Loat and Phegley.

* Asparagus officinalis L. Asparagus was seen at Principia and Oblate Fathers prairies.

Camassia scilloides (Raf.) Cory. Locally ahundant in some upland prairies of Illinois, wild hyacinth was found in hill prairie at Chautauqua.

Nothosiordum bizaliee (L.) Britt. False garlic, one of the most frequent plants in thin soil of cliff-tops in the Shawnee Hills of southern Lllinois, was observed on rocky slopes at Cave Creek and Government Rock.

Smilax bona-nox L. Fringed greenbrier, a dry-Woodland species, occurred in prairie at Fountain B'uff and Cave Creek.

Smilax hispida Muhl. [S. tamnoides var. hispida (Muh1.) Fern.] Common greenhrier was found in Hidden Lake and Phegley prairies.

Smilax rotundifalia L. This woodland species was seen in Phegley. Government Rock. and Cave Creek prairies.

\section{AMARYLLIDACEAE}

Agaìe itrginica L. American aloe was seen on stony slopes at Allen Lake and Cave Creek, and on loess slopes at Fults. Sampson, and Phegler. It was observed also on rock ledges at South Prairie du Rocher and Stotz. The mature plant. seem to flower every year. In thin soil on rock, the plants have short vertical stems and leaf-hases that vary in length with the depth of the soil. The Heshy roots radiate horizontally over the rock surface. In places, chiefly on rock ledges, the rosettes form fair-sized patches.

\section{IRIDACEAE}

* Belamcanda chinemsis (L.) DC. Blackberry-lily, an Asiatic species that is rery common on open wooded slopes in Pike and Greene counties, where it forms dense standi on the basal s'opes of the blutfs, was found in loem at Walmut Creck and in the wondland border at Swarnes.

Sisyrinchium albidum Rat. This blueeyed grass was found growing in loess in 11 hill prairies, most of them in southern Illinois.

Sisyriuchium campestre Bickn. This species occurred in $1+$ hill prairies in central and northern lllinois, trom El Rancho south to Block House.

\section{ORCHID.ICE IE}

Spiranthes cernua (L.) Rich. Nod. ding ladies-tresses were seen at Clen. denny. Reavis Spring. Bluff Springs, and Phegley, in each case in loess. They were fairly trequent at Reavis Spring.

\section{S.ALICACE.HE}

Populus deltaides Mlarsh. A tew individuals of eastern cottonwood were found in Lrsa and Homan hill prairies.

Populus grandidentata Michx. The large-toothed aspen, usually found on wooded hluffs, occurred as small trees in Menominee Station. Hill-Top, and South Palisades hill prairies.

Populus tremuloides Michx. Quaking aspen was observed in the prairie at Menominee Station, North Savanna, and Balk. It and the large-toothed aspen were "in" but not "of" hill prairie.

Solix humilis Marsh. Prairie willow was collected from six hill prairies.

\section{JLOCANDACEAE}

Carya texama Buckl. Buckley's or hlack hickory (including varieties) is a tree of dry upland words. Secellings acasionalls were found growing on the unper prairie slunes at Valmever, Sampson, and Phegley. Here it was found also at the hluff-top in the woodland horder.

Juglans nigra L. Snall individuals of black walnut were seen in Torth Savanna, Homan, Fall C'reck, Walnut Creek, and Vorth lildred prairics. large specimens were never found in prairie. only in the adjacent coves and bluff wood.

\section{BETULACEAR}

Corylus americana llalt. American hazel. a species of woorls and thickets. 
was seen in hill prairice at Sunset Trait and Ursa.

Ostrya zirginiama (.Mill.) K. Kuch. American hop-hornheam was found on four rockl prairie slupes and also on one loess slope. It was usually one of the trees found in worded coves.

\section{FAGACEAE}

() ueros albu L. W'bite oak saplings or small trees were observed in loes prairice at Sunset Trail, Hill-lop, and Fountain B Bluff.

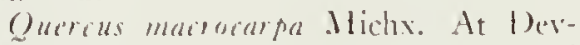
il's Backbone and Lrsa a few saplings of bur oak were found in the prairie. There and at other sites it was found also in the corves.

Querous marilandion Muenchh. Black jack was represcuted hy al few stunted individuals in the rock prairie at Government Rock.

Oueress mullembergii Engelm. Yellow or chinguapin oak occurred in 10 prairies. It was more abundant in clefts of limestone ledges, in coves, and on lower bluff sopes than in pravies.

(Ueress stellate Wangh. Post oak occurred as stattered individuals in seren pratries. It was common in woodland borders in soutlwestern fllinols.

Ouercus relutima Lim. Black oak, like other oaks a woolland species, was found in seren prairies, usually in the borders between prairie areas and upland woods, and octasionally as small solitary trees on the prairie slopes.

\section{ULMACFAE}

Celtis laevigatn Willd. Sugarberry, a suthern tree, most frequent in hottomlands. Was represented by one specimen in rock prairie at Govermment Rock.

Clmus alata Michx. Winged elm was found on the stony prairic slopes at Fountain Bluff, Government Reck, and Cave Creck.

ITmus rulsa Muht. Very smatl individuals of slippery elm were found in eight hill prairies.

\section{MORACEAE}

Haclura pomifura (Rat.) Schneid. Osage orange was wherved in the pastured loess prairie at $\mathbf{W}$ ilnut Creek and also in the prairie near woodland at Principia. In some other localities it was abundant in pastured woods on the hasal slopes of bluffs.

\section{CanNaBinacteaE}

Connabs satiza L. Common hemp, abundant in some pastured sand areas of Iltinois, was sern at South New Canton, al pastured hill prairie.

\section{SANTALACLAE}

Cosmandra umbellatn (L.) Nutt. $[C$. richardsiana lecrn.] Bastard-toadflax was foumd on 13 loess and 7 rocky prairie sopes from El Rancho and Devil's Batekbonce south to Renault.

Polyconachal

Polygrnum tenue Michx. Slender knotweed was collected from the rocky prairite slopes and the sandstone ledges at fountain Blulf.

\section{("H) NOPOHACEAL}

Ghenopodium leptophyllum Nutt. [C. pratericola Rrelb.] 'The narrow-leaved gromefoot was found in sandy loess at Balk and Rock C'reek.

\section{Nictaginaceae}

Mirabilis metaginea (Michx.) Mac Ml. Untrella-wort was found in only one hill prairie, Devil's Backhone.

\section{CARYOPHYLLACEAE}

Cerastium nutans Raf. Nodding mouseear chickweed occurred in Valmeyer and lountain Bluff prairies.

* Cerastium qulgatum I. Common mouse-ear chickweed was found in loess at Seehorn-Payson.

* Saponaria officinalis L. Bouncing-bet was found in loess at Homan.

Sile'ne antirrhina L. Sleepy catchfy was observed in nine rock or loess prairies and in crevices of rock ledges at the bases of four prairies.

\section{RANUNCULACEA}

Inemone canadensis L. Meadow anemwe was found in Bielema hill prairie.

Inemone cylindrien Gray. The longfruited anemone occurred in 14 hill prairies, mostly in loess. 
Anemone rirginiana L. Tall ancmone. or thimbleweed, was seen on three liress prairie slopes.

Aquilegia canadensis L. Wild columbine was found under a red cedar growing in loess at lorth Savanna. It was irequent on some rock ledges and in adjacent rocki woods.

Delphinium carolinianum var. crispum Perry. Blue larkspur was collected at Homan, Hidden Lake, and Sersiom. where it was growing in loess.

Ranunculus fascicularis Muh]. Tuited or early buttercup was found in Balk and Devil's Backbone prairies.

\section{LAL'RACEAE}

Sassafras albidum (Xutt.) Jees. Sassafras occursed as small individuals on four prairie slopes.

\section{FUVARIACEAE}

Corydalis montana Engelm. [C. aurea var. occidemalis Engelm.] This corydalis of rocky woods prairies, and glades (Palmer is Stevermark 1935) was found in the Valmeser prairie.

\section{Cruciferae}

Arabis lyrata L. This species of ruckcress occurred in loess at North Saranna and Baik, and on rock ledges at Menomince Station and Sunset Trail.

Draba reptans (Lam.) Fern. This small, incorspicuous species of whitlowcress grew in interstices at eight hill prairie stations.

* Lepidium campestre (L.) R. Br. Field peppererrass, or cow-cress, was seen in hill prairie only at Devil's Backbone.

* Lepidium densiforum Schrad. This introduced weed was seen in five of the hill prairies visited.

Lefidium rirginicum L. Common peppergrass. a weedy crucifer, was found in three hill prairies. It was in places more abundant in crevices of rock ledges at the base of a prairie slope than in the prairic itselt.

\section{SANTFRAGACEAE}

Hewchera richardsunii R. Br. Nlumroot was found in loess and on rocky slopes of 13 hill prairies from El Ranches to Cave Creek.
Ribes missourense Xutt. 'This contmon enoseberry. usually of wooks and thickets, accurred on the disturbed reskt slope uf Bielema prairie.

\section{ROS.ICENI:}

Iorimonies rosiellatu Wallr. Agrimuny was collected only at Chattin Brilge near the woudland border of one of the prairice openings there. It is a plant that is usually found in woodlands.

Imelanchier arburea (Michs. 1.) Fern. Serviceherry, usually of wooded hillsides, was observed on the rock-strewn slopes at Government Rock and Fountain Bluff. Is was seen in crevices and cletts in rock ledges neas other hill prairies.

Crataegus erus-galli L. Cockspur-thorn was $\dot{f}$ und on stony slupes at Cave Creek and in loess at Mud Creek and Pere Marquette. In there localities and in others it was found also in the woodland horders.

Cratuegus engelmanni Sare. This hawthorn grew on the rock slopes at Cave Creek.

Cratatyus mollis (T. \& G.) Scheele. Red haw, usually a small tree of thickets and woodland borders. occurred in Cave Creek prairie.

Fragarin itrginiana Duch. Strawhersy was collected in loess at Bluff Springs. Mud Creck, and Northeant Meredosia.

Walus iocusis (Wood) Britt. [Proms inensis (Wood) Bailey.] Wild crab, or lowa crahapple, was found as seedlings in six hill prairies. In the coves it was more frequent and the plants were larger than in the prairie areas.

Potentilla argutu Pursh. The tall cinquefoil grew on stons or lores slones of nine hill prairies in northern lllinois.

l'ofentilla simplex llichs. Common or old-field cinequeforil was found only at Sunset "l'rail, in locs.

l'runus lanata (Sudw.) Mack. ㅅ Bush. [1). americand var. lanafa Sudw.] Thin wild plum was found in reck prairie at Cave Creck. At uther sites if present, it occurred in the wordland border.

Rosa carolina L. "lhe pasture rose was found in rock prairic or in loes prairie at 12 sites. It was not common there. It is prohahly more common in llatland prairic. 
Rosa setigera Michs. One plant of the climbing rose was observed at Phegley: it was not seen in other hill prairies. This ruse is common in woodland borders.

Rosa suffulta Greene. [R. arkansana var. suffulta (Greene) Cockerell.] This rose was infrecpuent on loess slopes in four hill prairies.

Rubus flagellaris Willd. 'Tho dewberry was found in one loess prairic, Phegles, near a thicket-covered cove.

Rubus frondosus Bige?. 'T'his blackherry was sect on the rocky slopes at Chautautua prairie.

Rubus ocidentalis L. Black rapperr? was found in the ruck prarie at Menuminee Station.

\section{EGUMINOSAR}

Amorpha canescens Pursh. Leadplant grew in scattered patches in 23 rock or loess prairies from I:l Rancho and Devil's Backhone soutl to V'almever.

Astragalus conadensis L. This milkvetch occurred infrequently in loess at North Pandarmie, Principia, and Valmeyer. At Housen it was abundant in the woodland border at the crest of the ridge.

Istraqulus distortus T. A G. This small milk-setch was sten in loess, on rock! slopes, and in crevices of the rock ledge, at only one site, the Scehorn-Payson prairie.

Baptisia leacantha T. \& G. Wild indigo, or pratirie false-indigo, common in many of the upland prairies and in spen woods of Illinois, was found in only one hill prairie. Itill-'op.

Cassin fastirulata Michx. Partridgepea, common in hill prairies of southern Illinois, less frequent in those of northern Hllimois and along the Illinois River, was found in 20 prairies.

Cassiu nithons I. This cassia was found in the cherty ridge-top prairie at Tamms, the stony and loess prairies at Fountain Bluff, and the loess prairie at Phegley.

Cercis canadensis L. Redhud, usually found on forested rock! s'opes of bluffs. also was found in coves of hill prairies. Seedlings or very small trees were found occasionally on loess or rock prairie slopes.
Crotalariu sagittalis 1. Rattlebox was oberved in loess at Hill-Ton, Clendenny, and Principia.

Desmanthus illinoensis (Michx.) Mac.l. lllinois- or prairic-mimosa, was found growing in loess of two hill prairies, Pere Marquette and Principia. In both sites it was locally aluundant.

Desmodium canadense (1..) D $\therefore$. This tick-clover was found only in the rock pratirie at lit Rancho.

Desmodium ciliere' (Muhl.) DC. This species was collected at 12 stations from Clendenns south to Cave Creek. At Phegley and Sampson it grew also in the woodland.

Desmodium dillenit 1)arl." "This species was found in six hill prairies, Hidden lalke, Clendenny, Pere Marquette, Valmeyer, Fults, and Fountain Bluff.

Desmodium illinoense Gray. The Illinois tick-clover was collected in tive hill prairies in central fllinois; all specimens collected were from loess slopes.

Desmodium paniculatum (1.) DC. This species, predominantly of open woods and thickets, wats encountered in loess pratirie at nine sites.

Desmodium sessilifolium ('Torr.) T. A C. 'The sesile-leaved tick-clover was found at 22 sites, usually in loess prairie but occusionally on the rock-strewn slopes.

Galatiu qulubilis (L.) Britt. Milkpea was collected from rock prairie at Cave Creek and Government Rock.

Cleditsia triacanthos I. Honey locust grew in scattered groups in four hill prairies.

Lespedeza capitata Michx. This bushclover was a common plant on loess and occasionally on rocky prairie slopes. It was present in 27 of the 61 sites studied.

Lespedeza hiria (L.) Hornem. This lespedera was collected from the cherty prairie at Tamms and was observed in the woodland border at Government Rock.

Lespedeza intermedia (S. Wats.) Britt. This species was found in loess at fise prairie sites in southern Illinois.

Lespedeza procumbens Michx. Trailing hush-clower, a species of rocky woods,

- In the rreatment of this cenus in Groy's Manual. edition 8 , this entity has been segrerated into two species, Desmodium perplexism and D. glabellum. 
was encountered in five prairies, where it grew also in the wooded cores.

Lespedeza repens (L.) Bart. A tew. plants of creeping bush-clover were found in Sampson and Ursa hill prairies.

I Lespedeza simulata Mack. \& Bush. This species was collected from loess prairie at Renault and Fults, also on rocky prairie slopes of the latter.

* Lespedeza stipulacea Maxim. Korean clover or lespedeza was seen in I3 hill prairies. At Rock Creek it had been planted; elsewhere it apparently was an escape from the nearby pasturelands.

Lespedeza iiolacea (L.) Pers. Although usually found only in thickets and rocky woods, this lespedeza was seen in five prairies. It was more common, however, in the nearby wooded coves than on the prairie slopes.

Lespedeza irginica (L.) Brit. Slender bush-clover, a plant of woods, thickets, prairies, and glades, was seen growing in IS prairie sites, from Clendenny and Richwood south to Government Rock and Care Creek.

* Medicago lupulina L. Black medic, a European species, was observed in East Henry and MIud Creek prairies.

* Melilarus alba Desr. White sweet clover was seen in 25 hill prairies. It appeared to have been planted at Clendenny. lt formed a very dense stand at Hidden Lake.

* Melilatus officinalis (L.) Lam. Yellow sweet clover was less frequent than white sweet clover; it was found at five prairie sites.

Petalostemum candidum (Willd.) Michx. White prairie-clover was collected or observed at 19 prairie sites from Government Rock northward. It occurred abundantly in loess prairie at Homan, but at Phegley it was restricted to rocky wooded cores.

Petalostemum puгpureum (Vent.) Rydb. Purple prairie-clover occurred in +3 prairies from El Rancho and Devil's Backbone south to Government Rock.

Psoralea tenuifore Pursh. "The many" flowered psoralea occurred in 27 hill prai-

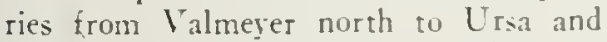
Standard. In some sites it was the must conspicuous species in early sumner. It is a distinctly western species and is very intrequent in Illimois other than in hill prairic.

Robinia pseudo-acacia l. Black locust, not native in lllinois, has spread from numerous plantations and was seen in four loess prairies.

Strophastyles heliola (L.) Ell. This wild bean of sand. rocky woods, or thickets was observed infrequenty in seven hill prairies.

Straphostiles leiosperma ( $\mathrm{l}$. \& G.) Piper. This species was ohsersed in two places, at Hill-Top and Rock lsland 31.

Stylasanthes biflora (I.) B.S.P. Pencilflower, a plant of rocky woods and also glades. was collected at Fountain Bluff on both rocky and loess prairie slopes and at Sampson in loess prairie near a cove.

Teplarosia rirginiana (L.) Pers. Goat i-rue, very common in the sand areas of Illinois, and occasional in drs, open woods with varying soil textures, was collected in a rock prairie at Government Rock. where it was abundant also in the woodland border, and in loess prairie at Oblate Fathers. Valmever, and Renault.

\section{LINACEAE}

Linum sulcatum Riddell. This annual Alax was observed in loess and occasionally in stony suil in 28 hill prairies from Bielema and Magnolia south to Allen Lake.

\section{OXALIDACEAE}

Oxalis stricta L. Upright yellow moodsorrel grew on rocky and luess prairie slopes at nine sites. It was found in cresices of ledges at two additional places.

Oxalis rrolacen L. Violet wood-sorrel was found at 25 sites. In some piaces it blossomed in spring and again in early autumn.

\section{CiERANIACEAE}

Geranium carolinianum I.. This weedy craneshill wa seen in fuur hill prairies in southwestern Illinois.

\section{RLTACEAE}

Ptelea trioliata I. Scattered mall in. dividuals of water-ash grew in 11 hill prairie. "lhis plant was more abundant in coses or un basal slopes of the blufts than in the prairies. 
Lanthoxylum americanum Mill. Prickly ash was seen in Balk prairie, where it wis growing in loess. "The woodlands adjoining many other prairies contained this species; only at Balk had it strayed into the prairie.

\section{Polygalaceae}

Polygala incarnata L. This milkwort was found in loess on the crest of the ridge at Northeast Meredosia.

Polygala a'erticillata L. 'This species, easily overlooked in its location between tutts of grass, was observed in nine prairies from Fountain Bluff northward.

\section{EUPHorbiacear}

Acalypha gracilens Gray. 'This threeseeded mercury grew on the rocky prairie slopes and sandstone ledges at Fountain Bluff.

Chamaesue gleptosperma (Engelm.) Small. [Euphorbia glyposperma Engelm.] 'This plant was found in rock prative at Devil's Backbone.

Chamaesyer maculata (L.) Small. [Euphorlia maculata 1..] Nodding spurge was seen in $1+$ hill prairies; in none of them was it abundant.

Chamaesyce supina (Raf.) Moldenke. [Euplorbia supina Raf.] Milk-purslane was found hetween the bunches of grass in six hill prairies. It was observed also in crevices of ledges.

Croton capifatus Michx. Hogwort was found only at Principia and Edgemont.

Croton glandulosus var. sepentrionalis Muell. Arg. Sand croton was found only: at Bluff Springs and Block House.

Croton monanthogynus Michx. Prairie-tea, a frequently encountered plant in hill prairie, was observed at 19 sites in central and southern Illinois.

Euphorbia corvllata L. Flowering spurge, a comnon plant in prairies, glades, and rucky ground, was found in 36 hill prairies, where it grew in loess and rocky soil. It was found also in some adjacent woodlands.

* Euphorbia cyparissias L. Cypressspurge, or cemetery cypress, was found in the Seehorn-Payson prairie as an escape from a nearby cemetery.

Eupharbia abtusata Pursh. This species was collected at Fults.
Poinsettia dentata (Michx.) Small. [Euphorbia dentata Michx.] This weedy species was found in 15 hill prairies.

\section{Anacardiaceae}

Rhus aromatica Ait. Fragrant sumac was seen in 15 hill prairies, either in loess or rocky soil. It was encountered also in sone wooded coves as well as in bluff-top woods.

Rhus aromation var. arenaria (Greene)

Fern. "This variety of the fragrant sumac was found in simdy loess at Bald Bluff, Balk, Bielema, and South Palisades.

Rhus copallina L. Shining or dwart sumac was found in loess at Southwest Edgemont, Chaltin Bridge, Fults, and Phegley.

Rhus glabra L. Smooth sumac was a very frecpuent plant in the hill prairies studied. It was observed on 33 rock and loess prairie slopes. It grew in coves and extended out on the spurs, or it grew in the borders of the bluff-top woods and out in the prairies as isolated individuals. In some places it was very dense and formed a thicket. In a few other places most of the individuals in open groups were dead or dying, a result possibly of fire, or of competition by grasses, competition intensified by summer drought.

Rhus redicans L. Poison ivy, erroneously called poison oak, was very abundant in woodlands adjacent to most of the hill prairies. It was found at Principia in loess and rock prairie.

\section{Aquifoliaceae}

Ilex decidua Walt. Possumhaw or swamp holly, normally found in bottom. land woods or on basal slopes of bluffs infrequently on shaded cliffs, was observed in a cove at Phegley, 200 feet above the adjacent bottomland.

\section{Celastraceae}

Celastrus scandens L. Bittersweet oc curred in eight hill prairies that adjoines woods. It occurred also in wooded cove: near prairie.

\section{RHAMNACEAE}

Ceanothus americanus L. New Jerse: tea, a plant of rocky woods, forest bor ders, and glades, was observed in 12 loes 
and in 2 rock prairies. It was found also in wooded cores nearbr.

\section{Vitaceae}

Titis spp. Stunted individuals of probably four species of grape were found in a number of hill prairies. No fruiting vines were found in these hill prairies.

\section{HYPERICACEAE}

*Hypericum perforatum L. Common St. John s-wort was found in two loess prairies, Sunset Trail and Bluffs.

Hypericum punctatum Lam. Spotted St. John s-wort was observed in five hill prairies in central and southern Illinois.

Hypericum sphatrocarpum Michx. Round-fruited St. John's-wort was seen in five prairies.

\section{Cistaceae}

Helianthemum bicknellii Fern. Frostweed, a plant of sand prairie, rocky prairie, and glade. was found in sandy loes: at Ilenominee Station and Sunset Trail.

Lechea leggettii Britt. \& Hollick. This pinweed was ohserved in loess at Menominee Station.

Lechea stricta Leggett. It was seen in hill prairie only at I almever.

Lechea rillosa Ell. This species was encountered at Principia.

\section{VIOLACEA}

Tiola pedata L. Bird-foot violet was not found frequently. It grew on rocky slopes at Government Rock and in loess at Balk and Deril's Backbone.

Iola rafinesquii Greene. [ $I$. kitaibeliana var. rafinesquii (Greene) Fern.] Field or wild pansi, a plant of prairies. roadsides, glades, and waste places, occurred in five hill prairies.

\section{LOASACE.AE}

Mentzelia oligosperma Yutt. Stickleaf, or few-seeded mentzelia, fig. 28. grew chiefly in crevices of rock ledges; it grew also on rocky slopes above the ledges. It was collected on ledges at North Pandarmie, Fults, and Phegley; on rock prairie, as, well as ledges, at Seehorn-Payson, Sessions, South New Canton. Swarnes, and Valmever. It was not observed in the hill prairies between Swarnes and
Valmever, nor north along the bluffs east of the Bluff Hall railsoad siding in . Idams County. In Illinois it is appitrently restricted to unglaciated bluffs or to those not slaciated since Kansan time. "This zenus is one of those of chiefly weitern distribution which reaches its ealitern limit in exposed xeric habitats in wertern lllinois.

\section{C.ACT.ICEAE}

Opuntia rafinesquii Engehm. [O. humiiusa Rat.] "The prickly pear was observed at 10 sites from Seehorn-Parson south to Phegley. It was found on rock ledges at Seehorn-Parson, Valmever, and Stotz; on rocky and loes slopes at Sessions. Housen, Chautauqua, Principia, Fults, Sampson, and Phegley:

\section{ONAGRACEAE}

Gaura biennis L. Biennial gatura, a plant of prairies, roadsides, and waste places. Was collected in Seehorn-Payson, Reavis Spring. Bluff Springs, Valmeyer, and Fults prairies.

Oenothera biennis I. Common evening primrose was seen infrequently in eight hill prairies.

Oenothera laciniata Hill. This evening primrose was found in 11 hill prairies in central and southern lllinois.

\section{CMBELLIFERAE}

Chaerophyllum sp. An unidentified species of this genus was found at Clendenny.

"Daucus carota L. Wild carrot was collected only at Pherley, where but few plants were tound

Polytaenia nutiallii $\mathrm{I}$ (. Prairie-parsler was tound growing in loess prairie and also at the border between prairie and rock ledges. It was collected at Rearis spring. Chautauqua, Valmeyer, and Fuli:

Spermolepis inermis (Nutt.) Math. \& Const. This umbellifer was found in lowes prairie and on rock ledges at secehwrn-Pas:on.

Taenidia integerrima (I.) Drude. Taenidia. or vellow pimpernel. wa. found on rocks slopes at Cave Creck. It was restricted principally to ilopes with - pare cover, or to comparatively bare 


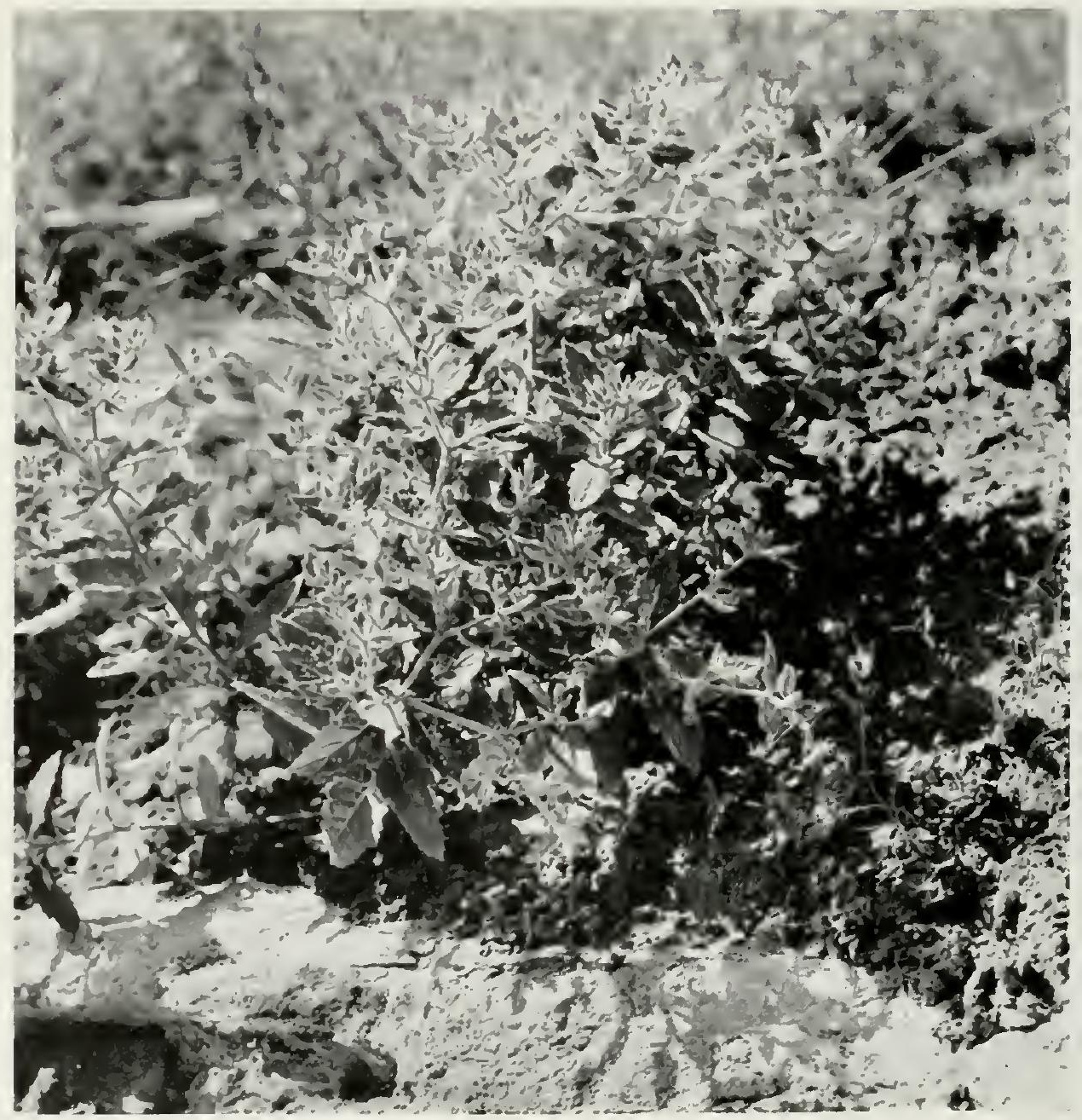

Fig. 28.-. Mentzelia oligosperma growing in thin loess just above a limestone cliff, south of New Canton, Pike County.

spaces just above or just below slopes. Presumably it cannot compete with vigorous species.

* Torilis japonica (Houtt.) DC. Hedge-parsley was found in hill prairie only at Chautauqua. This species seemingly is hecoming widespread in lllinois.

Zizin aurea (L.) Koch. Gulden alexanders, a plant of both prairie and forest, grew in the rock prairie at Cave Creek.

\section{CorxaceaE}

Cornus drummondi Mever. This dogwood. common in thickets and in woodland borders, was observed growing singly or in small thickets in loess prairie at 19 sites. It was common also in the adjoining coves.

Cornus forida L. Scattered individuals of flowering dogwood, a very attractive plant in springtime, were seen in Swarnes and Cave Creek prairies.

\section{ERICACEAE}

I'accinium arboreum Marsh. Farkleherry, or tree huckleherry, a plant of rocky woods, was collected in rock prairie at Government Rock.

I'acrinium zacillans 'Torr. Hill or low' hlueberry, a species of rocky woods, bluffs, 
and glades, grew on the sandstone ledges and in rock prairie at Fountain Bluff.

\section{PrINULACFAE}

Androsace occidentalis Pursh. This species was encountered on the rock ledges at Valmeyer and in the rock prairie at Devil's Backbone.

Dodecatheon meadin L. This shooting star, occurring in both prairie and forest in Illinois, was found in loess prairie at Reavis Spring and in the border of prairie and rock ledge at $\mathrm{V}$ almeyer.

\section{EBexacean}

Jiospyros rirginiana L. Persimmon occasionally was found growing as scattered individuals in the hill prairies of southern lllinois.

\section{Oleaceaf}

Fraxinus americana L. White ash, conmon in wooded coves, was found in a few hill prairies.

Fraximus nigra Marsh. Black ash was observed in the border between the rock ledge and rock prairie at Principia. It was observed in no other prairie.

\section{GeNTIANACEAE}

Gentiana quinquefolia L. Stift gentian was collected in loess at Wiersma.

Sabatia angularis (L.) Pursh. Rose gentian, or rose-pink, was collected from rock prairie at Sessions.

\section{APOCYNACEAE}

Apocsnum cannabinum l. Hemp dogbane, or Indian hemp, chiefly of open woods, glades, prairies, and roadsides, was collected at Principia and Fountain Bluff.

Apocynum sibiricum Jacq. "This dogbane was found in two prairies, SeehornPayson and Ursa.

\section{ASCleptadACEAF}

Asclepins amplcxicaulis Sm. This milkweed was collected from eight loess prairies.

Asclepias hirtella (Pennell) Moodson. [Acerates hirtella Pennell.] Although common in upland prairie in Illinois, it was collected in hill prairic only at Edgemont.
Asclepias quadrifolia Jace. 'This woodland milkweed was seen in rock prairic at Govermment Rock.

Isclepins stenophylla Grat. [dcerates angustifolia (Nutt.) Dene.] 'This spercies of green milkwerd was collected from eiglut hill prairies in Adams, Pike, and Cal. houn counties. In lllinois, it is apparently restricted to hill mairies.

Sislepias tuberosa 1. Butterfly-weed, common in some upland praities in Illinois, was found in but one hill prairie, Govermment Rock. It is one of the most attractive prairic plants. It can be successfully transplanted to home gardens.

Isclepias verticillata L. Horsetail or whorled milkweed, poisonous to livestock, was found in 18 hill privies, most of them in northern and central lllinois.

Asclepias quridiflora Raf. [dcerates riridiflora (Raf.) Eaton.] 'This green milkweed was common in hill prairies; it was observed in 20 of them.

POLFMONIACLAL

Phlox bifida Beck. Sand plilox was found in fire rocky prairies in southern Illinois, and in five sandy loess prairies in the 1 llinois River valley.

Phlox pilosa I. Downy phlox was found in five hill prairies, on either rocky or locess slopes.

\section{BORAGINACEAE}

* Iappula echimata Gilib. European stickseed was collected at Chautaupua in rock prairic.

Lithospormum canescens (Midix.) Lehm. This gromwell occurred on 2 roch and $1+$ loess prairic slopes.

Lithospermum croceum liern. Al. thougl common in sand prairie in Illinois, this species was collected in only two hill prairies, Sechorn-Payson and Nortl LIdred.

Lithospermum incisum Lelım. This narrow-leaved gromwell was very common in hill prairie from Bielema and Devil's Backbone south to Allen I ake. It was observed in 27 prairies.

Mosotis zerna Xutt. 'This forget-menot was found in the Fountain Bluff prairie.

Onosmodium occidentale . Mack. False gromwell or marblesered was seen in seren 
hill prairies from El Rancho and Rearis Spring to Cave Creek.

\section{V'erbexiceae}

l'erbena lracteata Lag. \& Rodr. 'This rervain, abundant along roadsides, was observed in hill prairie only at Balk.

I'erbena canadensis (L.) Britt. 'This attractive vervain, common on rocky bluffs in Monroe County, was collected at Fults and Remault in that county and at Government Rock in Union County.

lerbena simplex Lehm. The narrowleaved versain was found growing in seven hill prairies, in either rocky soil or loess.

Terbena stricta Vent. Hoary veruan was present in 42 hill prairies from El Rancho and Magnolia to Allen Lake.

\section{LABAAM}

Bleplilia ciliata (L.) Benth. Wood mint was collected on the rocky prairie lope at Deril's Backbone.

Cunila origanoides (1..) Britt. Stone mint was found in the rock prairie and on sandstone ledges at liuntain Bluff, and on a rock outerop at Government Rock. It was more abundant in adjacent open woods than in prairie areas.

Hederoma hispida Pur-h. Rough pennyrogal was present in many hill prairies and adjoining rock ledges from Menominee Station and Devil's Backbone soutl to South Prairic du Rocher.

Hedeoma pulegioides (1.) Pers. American pennyroyal, common in woodlands, was found in rock prairie at Ursa and in loess prairie at $1 \mathrm{Viersma}$.

Isanthus brachiotus (L.) B.S.P. False pennyroval grew in 10 rock and loess prairies and on 7 rock ledges from Fall Creek and Magnolia south to Cave Creek.

Monarda bradburiana Beck. [. H. russeliana Nutt. (?)] This species of bergamot was observed in three rock and three loess prairies in southern Illinois. It was commonly found also in open woods and thickets near hill prairies.

Monarda fistulosa L. Wild bergamot, common in prairie vegetation along roadsides and railroads, was seen in 16 hill prairies.

Mronarda punctata L. Spotted bergamot, locally abundant in sand prairies and barrens of 1 llinois, was found in sandy loess at $\mathrm{W}^{\top}$ alnut Creek.

* Nepeta cataria L. Catnip was found in hill prairie at South New Canton and Chautauqua.

Physostegia girginiana (L.) Benth. [l. angustifolin Fern. (?)] False dragonhead wats found in 16 hill prairies from Sescions and Reavis Spring south to Cave Creek. It was seen in loess and rock prairice and occasionally in crevices of rock ledges.

Prunella a'ulgaris 1. Selfheal, a common plant of wooks, fallow fields, and thickets, was observed growing in loess at Sunset Trail.

P'vcnanthemum Rexuosum (Walt.) B.S.P. 'This mint of open rocky woods, thickets, and fieldn was seen in hess at Oblate Fathers.

Pycnanthemum pilosum Nutt. This was the common mountain mint in 29 loess prairies from Sunset Trail and Reavis Spring soutl to Allen Lake.

"yenanthemum rivginianum (L.) Dur. A Jacks. 'This species was collected at lil Rancho, Ursa, and Block House.

Salvia pitcheri Torr. [S. azurea var. arandifora Benth.] Blue sage was collected from rock prairie at Cave Creek. This sage is a western species, with the eastern extent of its range from Minnesota to Kentucky coming through lllinois.

Sontellaria leonardi Epling. [S. parzula var. leonardi (Epling) Fern.] 'This small skullcap grew in 10 hill prairies. most of them in northern and central Illinois.

Scutellaria mata Hill. This skulleap was found in loess prairie at Valmeyer.

Scutellaria partula Michx. 'This small glandular-pubescent skulleap was seen in 10 rock and loess prairies and in crevices of 7 rock-ledge locations.

Teucrium canadense I. This woodage was found in small numbers in six loess prairies.

\section{SOLANACEAE}

Physalis heterophylla Nees. This ground-cherry was seen in seven hill prairies.

Physalis pubescens L. 'This pubescent annual ground-cherry was seen at Bluff Springs. 
Physalis virginiana Mill. Virginia ground-cherry was collected from six loess prairies in central and northern Illinois.

Solanum carolinense L. Horse-nettle was seen only in pastured loess prairie at Walnut Creek.

\section{SCROPH LLARIACEAE}

Asureolaria grandifora (Benth.) Pennell. [Gerardia grandiflora Benth.] False foxglore, a species of woods, openings, and thickets, was observed in loess at Sunset "Trail and Magnolia.

Buchnera americana L. Blue hearts, previously reported in Illinois only from Cook and Menard counties, was found in six hill prairies in Calhoun. Monroe, and Randolph counties.

Dasistoma macrophylla (Nutt.) Rat. [Seymeria macrophylla Nutt.] Mullein foxglove, commonly found in open woods and thickets, was found growing in loess at Swarnes hill prairie.

Gerardia aspera Dougl. This gerardia was seen in at least 17 hill prairies from northern to southern Illinois.

Gerardin gattingerj Small. This plant was seen in at least six hill prairies in south-central Illinois.

Gerardia skinneriana Wood. This plant of bluffs, sands, and harrens was found in four loess prairies.

Gerardia tenuifolia Vahl. This gerardia of wooded slopes was found in three hill prairies.

Pedicularis canadensis L. Wood-betony or common lousewort was found in loess prairie at North Eldred, where also it was very common in the wooded coves.

Penstemon pallidus Small. This pale penstemon was collected from 36 loess and rock prairie slopes and $1+$ rock ledges in 40 sites from Bielema and Devil's Backbone to Cave Creek. It was moderately abundant in many of these sites.

Scrophularia marilandica L. Usually. found in thickets and woodland borders. this figwort was collected from loess prairie at Balk.

Synthyris bullii (Eaton) Heller. [ / 'ulfenia Barnh.; Besseya Eaton.] This plant of sandy soil was collected from hill prairie at Bielema and Deril's Backbone. both sites near the margin of the $\mathrm{W}$ iscon$\sin$ glaciation.
* Terbascum thapsus 1. Common mullein was woserved in loess or rock prairie. or in crevices of rock ledges, in 17 hill prairies.

* Ieronica ariensis L. Corn-speedwell, a common European weed, was found infrequently in eight hill prairies.

léconica peregrina L. Purslane-speedwell, another weedy" sjecies, was collected from rock prairie at Fountain 13 luff.

feronscastrum tirginicum (I..) Farw. Culver's-root, a plant of woods, thickers, and prairies, was observed in seven hill prairies. In none of these was it so common as in flatland prairie.

\section{BIgNoNiaceae}

Bignonia capreolata L. Cross-rine, a southern species, was found as a stray at Cave Creek.

Campsis radicans (1.) Seem. Trumpetcreeper, common in woods, thickets, and fields in southern lllinois, was found in four hill prairies.

\section{Acaithaceal}

Rucllia humilis Nutt. Hairy ruellia was found in 30 hill prairies (also occasionally in crevices of rock ledges) from Bald Bluft and Deril's Backbone to Cave Creek.

\section{Plantaginaceae}

Plantago aristata Michs. The hracted plantain, a common roadside and openfield weed in compact soils of soutlicm Illinois, was collected from five hill prairies, in loess and in rocky soil.

Plantago purshii R. \& S. This western species of plantain, locally abundant in some sand prairies of the state, was found in sandy locss at Bielema and Bluff Springs.

Plantago rugelii 1)ene. "This plantain was seen in loess prairie at Principia and Hill-lop. In both sites it grew in the disturbed portions.

Plantago airginica 1. Hoary plantain, common in fields and rocky waste places, was found in 20 hill prairies.

\section{RUBHACEAE}

Diodin teres Walt. Rough huttonweed was collected from one loess prairie. Stotz. 
Galium aparine 1. Cleavers was found in nine hill prairies. le was nowhere very abundant in the prairies, but was common in the adjacent woodlands.

Galium circaezans Michx. Wild licorice, a plant of thickets and rocky woods, was found growing in three hill prairies. Also, it was seen in wooded coves.

Galium pilosum Nit. This hedstraw, a plant of thickets and rocky woods, was scen in three loess prairies and one rock prairie in southern Illinois. lt was found in wooded cores also.

Housfonia lanceolata (Poir.) Britt. This species of blucts was found at Cave Creck and lBlock House.

Houstonia longifolia Gaertn. "This species was encountered in rock prairie at Fountain Bluff and in loess prairie at Valmever.

Housconin nigricans (Lam.) Fern. "lhis narrow-leaved species of bluets was found growing abundantly in hill prairic from Swarnes to South Prairie du Rocher. escept at Block House, South Edgemont. Sugar Loaf, and Chalfin Bridge. It was present also at North lildred, Richwood, and Pere Marquette.

\section{CAPRIFOLIACHA:}

Symphoricarpos orliculafus Moench. Buckbrush, a plant of thickets, pastures, and open woods, was seen in 16 loess hill prairies. It was frequent in the coves; in places it formed open pure stands and was the only shrubby species present.

Triossenm perfoliatum L. Horse-gentian, or wild coffee, a species of open wooks and thickets, was ohserved in loess prairic at Fall Creek, Reavis Spring. Walnut Creck, and Block Houre.

I"iburnum rufidulum Raf. Southern blackhaw, a small tree or shruh of rocky woods, thickets, and glades, was found in rock prairie at Government Rock and Fountain Bluff. It was found in coves at Phegley and on the rock ledges at Renault, Chautauqua, and Clendenny.

\section{Campanulaceae}

Campanula rotundifolia L. [C. intercedens IVitasek.] This bellfower was collected from rock prairie at Bielema. It was also scen on the cliffs at Balk and on sandstone at Fountain Bluff.
Specularia perfoliata (L.) A. DC. l'enus's looking-glass, a plant of fallow fields, prairies, and waste places, was found growing in eight hill prairies.

\section{OBEIIACEAE}

Labelia spicatn Lam. Spiked or palespike lobelia was observed in 11 loess hill prairies.

Lobelia spicasa var. leptostachys (A. 1)C.) Mack. \& Bush. [L. leprostachys A. $D($ '.] "This variety was found in six loess hill prairies, in two of these prairies with the typical form of the species.

\section{CompositaE}

* Ichillea millefolium 1. Yarrow, common in pastures, waste places, along roadsides, and similar places, was found infre(puently in five hill prairies.

Aquseris ouspidata (Pursh) Raf. This plant was found in loess prairie at Reavis Spring.

Ambrosia coronopifolia 'T. A G. [A. psilostachya var. cormopifolia ( 1 . \& ( $\mathrm{C}$.) Fanw. Western ragweed was found in central lllinois hill prairies at Sessions, Reavis Spring, Northeast Meredosia, Bluffs, Walnut Creek, and Xorth Eldred. lt is abundant in the sand prairies of HHinois.

Imbrosia elatior I. [A. artemisiifolia var. clatior (1..) Descourtils.] The conmon ragweed was found in 12 loess hill prairics.

Ambrosia trifida L. Giant ragweed was found in hill prairie only at Chautauqua. It was observed in a disturbed part of the rock prairic and was only about 2 feet tall.

Antemnaria neglecta Greene. This small pussytues was found between the bunches of gras; at Menominee Station, Reavis Spring, Northeast Mleredosia, Bluffs, IValnut Creek, and North Eldred.

Antennaria plantaginifolia (L.) Hook. This species was seen in seven hill prairies. It was more abundant in the adjacent rocky open woods than in the prairie areas.

Artemisia caudata Michx. This wormwood, frequently encountered in sand prairies, was observed in rocky and sandy loess hill prairies at seven sites in northern and central Illinois. 
Aster anomalus Engelm. 'This aster, a plant of rocky wooded blufts, was found in hill prairie at Sessions and Fountain Bluff.

Aster azureus Lindl. The bright blue aster was found in 16 hill prairjes from Menominee Station and Reavis Spring south to Chalfin Bridge.

Aster ericoides L. (including 4 . coxiguus Rydb.). This weedy aster was seen in 18 hill prairies.

Aster linariifolius L. Abundant in sand prairie, this aster was collected from loess prairie at Vortheast Meredosia and Bunker.

Aster oblongifolius tutt. The oblongleaf aster, frequently seen on rocky bluff:. was collected from 36 sites in loess and rock prairies; also it was observed in crevices of rock ledges. in recesses on small clifts, and on rocky wooded slopes. It ranged from El Rancho and Devil's Backbone south to Care Creek.

Aster parideps (Burgess) Mack. i Bush. An aster. possibly this species, was collected from rock prairie at Chautauqua and from loess prairie at Fall Creek, Seehorn-Payson, and Sessions.

Aster patens tit. The spreading aster was seen in 13 hill prairies from Clendenny to Cave Creek.

Aster pilosus Willd. Heath aster. a weedy species, was present in 16 hill prairies. It was not so common there as in flatland prairies.

Aster ptarmicnides (Nees) T. E G. White upland aster was found at liersma and Rock lsland 31 prairies.

Aster sagittifolius Wedem. The arrow aster, usually found in open wood. occurred in the rocky prairie at Government Rock and in loess prairie at Clendenny:

Aster sericeus Vent. Silky aster was collected from 10 loess hill prairies from Bielema and Reavis Spring south to Renault. It was not very abundant at these sites.

Aster turbincllus Lindl. This aster was found in loess and rock prairie at Fountain Bluff. At Gorernment Rock it grew in crevices of rocks, and also in the woodJand border. but not in the prairie.

Cacalia atriplicifolia L. Pale Indianplantain. which grows in a variety of habitats, open woods, thickets, and prairies, was encountered in loess praitie at four sites and also in coves at two of these places.

Cacalia tuberosa Nutt. This speciewas seen in loess prairie at Bielema. Balk. Rald Bluff, Swarnes, Sampson, and Soutl Prairic du Rocher.

Chrysopsis zillosa (Pursh) Xutt. [C. camporum Greene.] Golden aster was found in loess at three sites along the Mississippi and at five along the lllinois River.

Coneopsis lanceolata L. Lance corcop$\therefore i$ was found in rocky soil at Fults; in loess at Reavis Spring. Valmever, and Fults: and on rock ledges at Fults and Stotz.

Coreopsis lancenlata var. iillosa . Michx. [C. crassifolin tit.] This variety was found in loess prairie at Valmeyer, Fults. and South Prairie du Rocher.

Corcopsis palmata Nutt. Finger coreopsis occurred in more prairies than the preceding species and rariety. It was seen in 11 prairies from Sunset Trail and Standard south to Renault.

Coreopsis tripteris L. Tall coreopsis was seen in loess prairie at Fountain Bluft.

Echinacea pallida (Nutt.) Vutt. Pale coneflower was observed in 18 hill prairie. from Bielema and Magnolia south to Cave Creek.

Eriqeron annuus (L.) Pers. White(0\%), of daisy-fleabane, common in fallow ticlds prairies, and waste places, was observed in only two hill prairies. Chantauqua and Oblate Fathers.

Erigeron canalensis L. Horse-weed or mule tail, a common weed, was observed in 10 hill praicies.

Frigeron dicariasus Wichs. Spreading Aeabane was found in a pastured hill prairie, Seehorn-Payson.

Erigeron strigosus Muhl. "This fleabane was observed in to hill prairies. Possibly it occurred in some of the other prairies that were visited but once during this study:

Eupatorium altissimum L. 'Tall thor. oughwort. common in pastures, rocky hills. thickets, and along roadsides, was ohserved at 35 sites from Sunset Trail and Magnolia to Cave Creek. 
Guaphalium obtusifolium L. Catfoot, old-field balsam, or sweet everlasting, was observed in 15 hill prairies.

Helianthus dizaricatus L. 'This sunHower of dry woods and thickets was seen in 13 hill prairies, often on the upper slopes toward the crests of the ridges.

Helianthus mollis Lam. Ashy sunHower, common in some upland prairies, was collected from loess hill prairie and the woodland border at Clendenny.

Helisnthus occidentalis Riddell. This sunflower was found growing in loess at East Henry and Bunker.

Helianthus rigidus (Cass.) Desf. [H. laetiforus vat, rigidus (Cass.) Fern.] Prairie sunflower was seen in five hill prairies from Swarnes to Renault.

Heliunthus strumosus L. This sunHower was encountered in loess at Southwest Edgemont, Valmejer, and Renault. At Fults and Fountain Bluff it was found in wooded coves.

Meliopsis helianthoides (L.) Sweet. The scabrous form (var. scabra (Dunal) Ferul.] of sunflower heliopsis was found in loess at Block House.

Kuhnia cupatorioides L. False boneset was a common species in hill prairie. It was seen in rock and loess prairies from El Rancho and Devil's Backbone to Cave Creek.

Lactuen cunadensis L. This wild lettuce was found in loess at four hill prairies. Only a few isolated plants were prexent at each of these sites.

* Lactura scariola L. Prickly letuce was seen only in the pastured 17 alnut Creek prairie.

Liatris aspera Michx. This blazingstar or gav-feather was ohserved in 12 hill prairies from Sunser 'Trail and Devil's Backbone to Grand Canyon.

Liatris cylindracen Michx. The cylindric blazing-star was collected from loess prairie at North Eldred, Chautauqua, Principia, Block House, Valmeyer, Fults. and Sampson; at Sunset Trail it was observed in crevices of rock ledges.

Liatris scabra (Greene) K. Schum. This species was collected in rock prairie at Cave Creek and Fountain Bluff, where it occurred also in loess prairie and in crevices of the sandstone ledges. At Government Rock (in the type locality for this species) it was collected in rocky woudlands.

Ratibida pimnata (V'ent.) Barnh. Prairie coneflower, common in upland prairie, was found in nine scattered hill prairies.

Rudbeckia missouriensis Engelm. This coneflower apparently is restricted in its range in Illinois to Monroc and Randolph counties, where it was found in four hill prairies, Valmeyer, Fults, Sampon, and Phegley (Evers 1951).

Rudleckin serotina Nutt." Black-esed Susan was found in 12 hill prairies. It was not common at any of these sites.

Senecio panperculus Michx. This ragwort was found in loess at Sunset Trail.

Senecio plattensis Nutt. Prairie ragweed was found in scattered hill prairies from North Savanna and Reavis Spring to Stotz..

Silphinm integrifolium Michx. Rosinweed was found in scattered hill prairies from Fall Creek and East Henry to Cave Creck.

Silphium laciniatum 1. Compassplant was collected in four loess hill prairies, Swarnes, East Henry, Reavis Spring, and North Eldred.

Silphium terebinthinaceum Jacy. 'This species was found at Valmeyer and Cave Creek. Scattered individuals at Cave Creek can he referred to the variety pinnatifulum (Ell.) Gray.

Solitago altissima L. Tall goldenrod was found in eight hill prairies from Wiersma to 'Tamms.

Solidago canadensis 1. This species was found in loess at El Rancho, Sunset Trail, and Wiersma.

Solidago drummondii T. \& G. Drummond's goldenrod was found in hill prairie at Yorth Eldred. Chautauqua, Pheglev, and Fountain Bluff. It was collected also from crevices in rock ledges at Richwood, Valmever, Fountain Bluff, and Government Rock.

Solidago missouriensis var. fasciculata Holz. [S. glaberrima Martens.] Prairie goldenrod was seen at Principia and Tamns.

This name was applied by Fernald (1950) to our common black-eyci Susan. He separated it from $R$. hiria $L$. on the shape of the basal and cauline leaves. The snecific name serning is used in this paper although further study of the plant in the field and of herbarium specimens may show it not specifically distinct from $R$. hitia I.. 
Solidago nemoralis Ait. Field goldenrod was found to be the most ahundant goldenrod of the hill prairies. It was ohserved in 33 loess and rock prairies in Jllinois.

Solidago petiolaris Ait. This species was found in cherty prairie at Tamm.

Solidago radula Nutt. Rough go!denrod 1 as found in 15 hill prairies from North Pandarmie and North Eldred south to Government Rock.

Solidago rigida L. Rigid goldenrod. common in flatland prairie remnants, was seen in hill prairie at El Rancho, Rearis Spring, Block House, Valmerer, Renault, and Government Rock.

Solidago speciosa Vutt. Showy goldenrod was collected from loess prairie at Sunset Trail. Devil's Backbone, and Valmever.

Solidago ulmifolia Muhl. Elm-leared goldenrod, a plant of thickets and open woods, was found in six hill prairies, chiefly in stony soil.

* Tragopogon major Jacq. [T. dubius Scop.] This European species was found in the rock prairie at Devil's Backhone.

*Tragopogon pratensis L. Goat'sbeard was found in loess prairie at Sunset Trail and Ohlate Fathers.

l'erbesina helianthoides Michx. This crownheard, usually found growing in dry woods and thickets, was seen in rock prairie at Fountain Bluff and Cave Creek and in loess at Chautauqua and Fountain Bluff.

I'erbesina irirginica 1. White crownbeard, or tickweed. was collected from rock prairie and woodland horders at Cave Creek.

Ternonia baldacini Torr. "This ironweed was found in loess at six hill prairies from Sessions and North E!dred south to Sampson.

Vernonia missurica Raf. More generally present in hill prairie than the preceding species, this ironweed was found in 11 loess hill prairies and in some of the adjoining wooded coves.

Three hundred ninety-four species and varieties of plants were found by the writer in the hill prairies of Illinois. Of these, 390 were vascular plants distrihuted among 209 genera and 70 families. "1"he family represented by the greatest numbers of species and genera was the Compositae, 71 species and varieties in 26 genera. . Ister was the largest genus; 12 species were represented. The four species of nonvascular plants included two species of the lichen Lecidea, a liverwort, and a moss.

\section{Geographical Relations of the Hill Prairie Flora}

The majority of plant species in $1 / l i$ nois hill prairies are presumably of southeastern origin. Three of the important grass species, Indropogon scoparius, $t$. gerardi, and Sorghastrum nutans, came from southeastern United States.

There are, however, numbers of species characteristic of the western plains and of the Ozark plateau. These are Bouteloun hirsuta. Psoralea tenuiflora. Polytaenia nuttallii. Asclepias stenophilla. Mentzelia aligosperma, Salita pitcheri, Plantago purshii, Agoseris cuspidata, tmbrosin cromopifolia. Solidago drummondii, tster anomalus, and Rudbeckin missouriensis.

The last three possibly are from the Ozark plateau. In addition to the plants enumerated ahose, Symthyris bullii may he mentioned is a species, possibl from the Rocky Mountains, that migrated eastward along glacial moraines (Pennell 1935 ).

\section{SLMMARY}

1. Hill prairies are graslands on pronounced slopes. Prairies is here used as a regetational term rather than a locationat or topographic term for an expansive flat.

2. Of the many hill prairies in Hllinis, 61, with a combined area of more than 200 acres, were visited by the writer in the course of this study.

3. In lllinois, hill prairies occur on the exposed upper or hrow slopes of the erenerally southwest- and west-facing bluffs east of the Mississippi River for most of the length of the state and on similar slopes along the Illinois River from Putnam County southward into Jersey Ciunty, where the valley of the lllinosis enters the Mississippi valley. Hill pratiries ate present also alon:r the Sangamon and Rock rivers.

t. Location and topography evert the sirongest controls, or place influences, that 
determine the occurrence of prairie on the upper slope of a bluff. The west- to southwest-facing position of the slope, which exposes the slope directly to the hot rays of the afternoon sun and to prevailing southwest summer winds, and the altitude of the bluff and width of the adjacent bottomlands help to provide the extremely xeric conditions under which this type of prairie thrives. Rapid and excessive drainage, due both to slope and to permeable loess substratum, is a reinforcing condition.

5. "The regetation of 1 llinois hill prairies is the bunch-grass type, with $A n d r$ opogon scoparius the dominant species in most stands. Bonteloua curtipendula is usually present, in a few prairies dominant. In a few hill prairies, Sorghastrum nutans and a few other bunch grasses occur frequently and may dominate small areas within the prairie, or, rarely, the entire stand.

6 . For detailed studies of the vegetation, plots were staked in unpastured and in pastured variants of the same prairie slope. Data were obtained from plot sizes ranging from 1250 milacre to 9 milacres. The smallest size found to be effective was $1 / 6+$ milacre. "1he largest area staked in each prairie was 75 milacres. One milacre in each prairie-pastured and unpastured-was mapped. All plant individuals were charted and counted in each of these milacres. Species lists were compiled for plots of the several sizes.

7. In the mapped milacre of the unpastured prairie, the estimated number of plants was 1,$949 ; 1,40+$ of these were $d n$ dropogon scoparius. In the mapped milacre of the pastured prairie, the estimated number of plants was $1,3+1 ; 849$ of these were 1. scoparius.

8. The ground space occupied by plants in the mapped milacre of the unpastured prairic was $1.88+.1$ square inches, of which 1,781.0 square inches were occupied by Andropogon scoparius. In the mapped milacre of the pastured prairie the ground space occupied by plants was found to be $1,+03.3$ square inches, of which $1,107.0$ square inches were occupied by $A$ scoparius. In the unpastured prairie, at ground surface, 69.96 per cent of the mapped milacre was bare loess; in the pastured prairie, 77.63 per cent.

9. In the mapped milacre of the unpastured prairie, foliage covered 4,988 square inches, approximately 80 per cent of the milacre. In the mapped milacre of the pastured prairie, foliage covered 2,525 square inches, about to per cent of the milacre. In both pastured and unpastured prairic, Andropogon scoparius was the species with the largest foliage area. In the unpastured milacre, approximately 20 per cent of the ground was not covered by foliage; in the pastured milacre, about 60 per cent.

10. The available space per plant in the unpastured milacre was found to he 3.22 square inches; in the pastured milacre it was 4.68 square inches.

11. For the study of frequency of occurrence of species in plots within hill prairie, a good distribution of species was obtained with quadrat sizes of $1 / 6+$ to $1 / t$ milacre in unpastured prairie; 1/16 to $1+$ milacre in pastured prairie.

12. From species-area curves, the smallest representative area-the smallest one-piece area having some claim to be representative-was determined for the unpastured prairic as 0.76 milacre, and, for the pastured, 1.26 milacres. 'The minimum area for assignment to type-an area that is large enough to include all the important and a moderate number of minor species-was determined as $3.80 \mathrm{mil}$ acres for the unpastured and $6.30 \mathrm{mil}$ acres for the pastured prairie. The fairsized stand-an area that is 50 times as large as the smallest representative area and contains twice as many species-was 38.0 milacres for the unpastured and 63.0 milacres for the pastured hill prairie.

13. The flora of 36 hill prairies was used as a basis for presence studies. The "constants" (species in 29, 80 per cent, or more of the 36 locations) of this type of prairie in lllinois were Andropogon scoparius, Erigeron strigosus, Bouteloua cur. tipendula. Petalostemum purpureum, Euphorbia corollata, Penstemon pallidus, A. gerardi, Verbena stricta, and Kuhnia eupatorioides. Twenty-five species were found in 18 or more of the 36 prairies used in this study of presence. Species most characteristic of the hill prairie type 
(i.e., of much lower presence in other prairie types in lllinois) were Bouteloua curtipendula, Psoralea tenuifora, Petalostemum candidum, Linum sulcatum, and Lithospermum incisum.

14. Prairie stands possibly existed on the hluffs that now support prairie from Wisconsin or pre-Wisconsin time to the present. 'This regetation will presumably continue to grow on these sites until a clange in climate occurs which will provide more mesic conditions, or until advanced erosion of the hluffs forms a continuously gentle slope, or until high cliffs are reduced.

15. The observed flora of Illinois hill prairie was 394 species and varieties. Of these, 390 were vascular plants distrihuted in 209 genera and 70 families. The largest family was Compositae, with 26 gen- era and 71 species and varieties. Aster was the largest genus, with 12 species. Thirty species were of foreign origin.

10. Although most species of Illinois hill prairie plants are of southeastern origin, nine species are distinctly western or southwestern, and three are from the Ozark plateau. Of these 12 species, Mentzelia oligosperma, Asclepias stenophylla, and Rudbeckia missouriensis are seeningly restricted to hill prairie and adjacent rock ledges.

17. Some prairie slopes are grazed, and some are annually or less frequently hurned, yet the prairie persists. As these steep slopes have never been plowed, they represent one of the least disturbed types of prairie in Illinois, and some of them should he preserved. 


\section{$L I T E R A T U R E$ CITEI}

Bush, B. F.

1895. Notes on the mound Hora of Atchison County, Misouri. Mo. Bot. Gard. Ann. Rep. $6: 121-34$.

Chanherlin, T. C.

1897. Supplementary hypothesin respecting the origio of the loess of the Mississippi Valley. Jour. Geol. $5(8): 795-802$.

Costello, David F.

1931. Comparative study of river blutf succession on the Iowa and Nebraska sides of the Missouri River. Bot. (iaz. 91:295-307.

Deanr, Charles C.

19+0. Flora of Indiana. Department of Conservation, Division of Forestry, Indianapolis, Indiana. 1,236 pp.

Ellsworth, H. I.

1837. Illinois in 1837. S. A. Mitchell, Philatelphia. 1+3 pp.

Fivers, Robert $A$.

1951. Four plants new to the Illinois Hora. Rhodora 53(628):111-3.

Fernald, Nerritt Lyndon

1950. Gray's Manual of Botany. Eal. 8. American Book Company, New York. 1,632 pp.

Gates, Frank Caleh

1912. The vegetation of the Beach area in northeastern Illinois and southeasterm Wisconsin. III. Lab. Nat. Hist. Bu\}, 9(5):255-372.

\section{Gleason, Henry Allan}

1910. The vegetation of the inland saud deposits of Illinois. 11l. Lab. Nat. Hist. Bul. 9(2):23-17t.

[1923.] The regetational history of the Micldle West. Assn. An. Geog. Ann. 12:39-85. (Volume dated 1922.)

1952. The new Britton and Brown illustrated flora of the northeastern [uited States and adjacent Canada. Vol. 1. The P'teridophyta, Gymmospermae and Honocotyledoneae. New York Butanical Garden [New York, N. Y.]. +82 pp.

llanson, Herhert C.

1922. Prairie inclusions in the deciduous forest climax. Am. Jour. Bot. 9(6):330-7.

Hitcheock, A. S.

1950. Manual of the grasses of the Cnited States. Ed. 2 (revised by Agnes Chase). IT. S. Dept. Ag. Mlisc. Pub, 200, 1,051 pp.

Hopkins, Harold 1 i.

1951. Ecology of the native vegetation of the loess hills in central Nebrasta. Ecol. Monog. 2l (2) $: 125-47$.

Hus, Henri

1908. An ecological cross section of the Minissippi River in the region of St. Louis, Missouri. Mo. Bot. Gard. Ann. Rep. 19:127-258.

Jones, George Neville

1950. Flora of Illinois. Ed. 2. Cniversity of Xotre Dame Press, Notre Dame, Indiana. $368 \mathrm{pp}$.

Korstian. Clarence F., and Theodore S. Cuile

193\$. Plant competition in forest stands. Duke L'niv. Forestry Bul. 3. 125 pp.

Leighton, Morris M., and H. B. Willman

1950. Loess formations of the Misinsippi Valiey. Jour. Geol. 58(6):599-623.

leonard, A. Brron

1952. Illinoian and Wisconsinian molluscan faunas in Kansas. Kans. Tniv. Paleontol. Con trib., Mollusca 4. 38 pp.

Leonard, A. Byron, and John C. Frye

1954. Ecological conditions accompanying loess deposition in the Great Plains region of the United States. Jour. Geol. 62 (t):399-40t. 
Marks, John B.

19+2. Land use and plant succession in Coon Valley, Wisconsin. Ecol. Monog. 12(2):113-33

Page, John L.

19+9. Climate of lllinois. 111. Ag. Exp. Sta. Bul. 532:93-36t.

Palmer, Ernest J., and Julian A. Steyermark

1935. An annotated catalogue of the flowering plants of Missouri. Mo. Bot. Gard. Ann. $22(3): 375-758$.

Pammel, I. H.

1896. Notes on the flora of western lowa. Iowa Acad. Sci. Proc. 3:106-35.

1899. Some ecological notes on the Muscatine flora. Plant World 2(11):182-6.

1902. Preliminary notes on the flora of western lowa, especially from the physiographical ecological standpoint. lowa Acad. Sci. Proc. 9:152-80.

Peck, J. .M.

1834. A gazetteer of lllinois. R. Goudy, Jacksonville [1llinois]. $376 \mathrm{pp}$.

Pennell, Francis W.

1935. The Scrophulariaceae of eastern temperate North America. Acad. Nat. Sci. Phila. Mlonog. 1. $650 \mathrm{pp}$.

Russell, Richard Joel

19+4. Lower Mississippi Valley loess. Geol. Soc. Am. Bul. 55(1):1-t0.

Sargent, C. S.

1889. Portions of the journal of André Michaux, botanist, written during his travels in the United States and Canada, 1785 to 1796 . With an introduction and explanatory notes by C. S. Sargent. Am. Philos. Soc. Proc. 26(129):1-1+5.

Shaffer, Paul R.

1954. Extension of Tazewell glacial substage of western Illinois into eastern Iowa. Geol. Soc. Am. Bul. 65 (5): $+13-56$.

Shimek, B.

1896. A theory of the loess. Lowa Acad. Sci. Proc. 3:82-9.

1903. Living plants as geological factors. Lowa Acad. Sci. Proc. 10:+1-8.

1910a. Geology of Harrison and Monona counties. lowa Geol. Surv. Ann. Rep., 1909, $20: 271-485$.

1910k. Prairie openings in the forest. lowa Acad. Sci. Proc. 17:16-9.

1911. The prairies. Iowa Univ. Lab. Nat. Hist. Bul. 6(2):169-2t0.

1924. The prairie of the Mississippi River bluffs. lowa Acad. Sci. Proc. 31:205-12.

Short, C. W.

18+5. Observations on the botany of Illinois, more especially in reference to the autumnal flora of the prairies. West. Jour. Med. and Surg., n.s., 3:185-98.

Smith, Guy D.

1942. Illinois loess-variations in its properties and distribution: a pedologic interpretation. 111. Ag. Exp. Sta. Bul. 490:137-84.

Steiger, T. L.

1930. Structure of prairie vegetation. Ecology 11(1):170-217.

Steyermark, Julian A.

1940. Studies of the vegetation of Missouri-1. Natural plant associations and succession in the Ozarks of Missouri. Field Mus. Nat. Hist. Bot. Ser. 9(5):3+7-475.

Turner, lewis $M$.

193+a. Grassland in the floodplain of lllinois rivers. 1ll. Acad. Sci. Trans. 26(3):71-2.

$193+b$. Grassland in the floodplain of Illinois rivers. Am. Midland Nat. 15(6):770-80.

Udden, J. A.

1894. Erosion, transportation, and sedimentation performed by the atmosphere. Jour. Geol. 2(3): $318-31$.

Vestal, Arthur G.

1913. An asmociational study of Illinois sasd prairie. I1I. Lab. Nat. Ilist. Bul. I0(1):I-96.

1918. Local inclusions of prairie within forest. Ill. Acad. Sci. Trans, 11:122-6. 
1931. A preliminary vegetation map of Illinois. Ill. Acad. Sci. Trans. 23(3):204-17.

1945. Flora of Jllinois. [A review of a hook with that title.] Science, n.s., 102(2656):5+2-3.

1949. Mininum areas for different vegetations: Their determination from species-area curves. IHI. Biol. N lonog. 20(3):1-129.

Vestal, A. G., and H. Bartholomew

1941. Prairie of Joess bluffs of the Illinois River. (Abs.) Ecol. Soc. Am. Bul. 22(t):t1.

Vestal, Arthur G., and Mary Frances Heermans

19+5. Size requirements for reference areas in mixed forests. Ecology 26(2):122-34.

Woodard, John

1924. Origin of prairies in Illinois. Bot. Gaz. 77(3):2+1-61.

Worthen, A. H.

1868. Geological survey of Jllinois. Vol. 3. Geology and palateontology. [Illinois Geologica] Survey, Springfield.] $57+p$. 



\section{SOME RECENT PUBLICATIONS}

\section{A.-ILLINOIS NATURAL HISTORY SURVEY BULLETIN.}

Volume 25, Article 1.-Characteristics of Residual Insecticides Toxic to the House Fly. By Willis N. Bruce. July, 1949. 32 pp., frontis. + 14 figs., bibliog.

Volume 25, Article 2.-Effect of Permanent Flooding in a River-Bottom Timber Area. By Lee E. Yeager. August, 1949. 34 pp., frontis. + 21 figs., bibliog.

Volume 25, Article 3.-Canada Geese of the Mississippi Flyway, with special reference to an Illinois flock. By Harold C. Hanson and Robert H. Smith. March, 1950. 144 pp., frontis. +82 figs., bibliog.

Volume 25, Article 4.-Biology of the White Crappie in Illinois. By Donald F. Hansen. August, 1951. 56 pp., frontis. + 13 figs., bibliog.

Volume 25, Article 5.-Commercial and Sport Fishes of the Mississippi River Between Caruthersville, Missouri, and Dubuque, Iowa. By Paul G. Barnickol and William C. Starrett. September, 1951. 84 pp., frontis. + 10 figs., bibliog.

Volume 25, Article 6.- Tularemia, Weather, and Rabbit Populations. By Ralph E. Yeatter and David H. Thompson. June, 1952. 32 pp., frontis. + 29 figs., bibliog.

Volume 26, Article 1.-The Mayflie3, or Ephemeroptera, of Illinois. By B. D. Burks. May, 1953. 216 pp., frontis. + 395 figs., bibliog. $\$ 1.25$.

Volume 26, Article 2.-Largemouth Bass in Ridge Lake, Coles County, Illinois. By George W. Bennett. November, 1954. 60 pp., frontis. + 15 figs., bibliog.

Volume 26, Article 3.-Natural Availability of Oak Wilt Inocula. By E. A. Curl. June, 1955. 48 pp., frontis. + 22 figs., bibliog.

Volume 26, Article 4.--Efficiency and Selectivity of Commercial Fishing Devices Used on the Mississippi River. By William C. Starrett and Paul G. Barnickol. July, 1955.42 pp., frontis. + 17 figs., bibliog.

\section{B.-ILLINOIS NATURAL HISTORY SURVEY CIRCULAR.}

32.-Pleasure With Plants. By L. R. Tehon. February, 1952. (Fourth printing, with revisions.) 32 pp., frontis. +9 figs.

38.-Windbreaks for Illinois Farmsteads. By J. E. Davis. February, 1954. (Fifth printing, with revisions by L. B. Culver.) 34 pp., frontis. +27 figs.

39.-How to Collect and Preserve Insects. By H. H. Ross. June, 1953. (Fourth printing, with alterations.) 59 pp., frontis. + 65 figs.

41.-How to Recognize and Control Termites in Illinois. By B. G. Berger. February, 1947. (Reprinted without text revision, April, 1950.) 44 pp., frontis. + 32 figs.

42.-Bird Dogs in Sport and Conservation. By Ralph E. Yeatter. December, 1948. 64 pp. frontis. +40 figs.

43.-Peach Insects of Illinois and Their Control. By Stewart C. Chandler. December, 1950. 63 pp., frontis. + 39 figs.

44. - The Drug Plants of Illinois. By Leo R. Tehon. July, 1951.135 pp., frontis. + 262 figs. 45.-Housing for Wood Ducks. By Frank C. Bellrose. February, 1955. (Second printing, with revisions.) 47 pp., illus., bibliog.

C.-ILLINOIS NATURAL HISTORY SURVEY MANUAL.

2.-Fieldbook of Illinois Land Snails. By Frank Collins Baker. August, 1939. 166 pp., color frontis. + 170 figs., 8 pls. $\$ 1.00$.

3.-Fieldbook of Native Illinois Shrubs. By Leo R. Tehon. December, 1942. 307 pp., 4 color pls. +72 figs., glossary, index. $\$ 1.25$.

List of available publications, about 400 titles, mailed on request.

Single copies of IllinoIs Natural History Survey publications for which no price is listed will be furnished free of charge to individuals until the supply becomes low, after which a nominal charge may be made. More than one copy of any free publication may be obtained without cost by educational institutions and official organizations within the State of Illinois; prices to others on quantity orders of these publications will be quoted upon request.

\section{Address orders and correspondence to the Chief Illinois Natural History Survey Natural Resources Building, Urbana, Illinois}

Payment in the form of money order or check made out to State Treasurer of Illinois, Springfield, Illinois, must accompany requests for those publications on which a price is set. 

